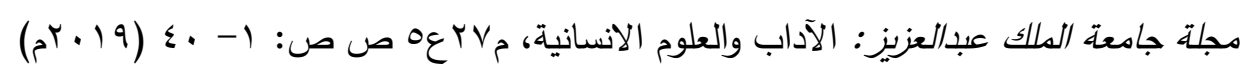

DOI:10.4197/Art.27-5.1

\title{
دلالة حرف الباء دراسة أصولية تطبيقية
}

\author{
د. عبد الوهاب بن عايد بن عويضه الأحمدي

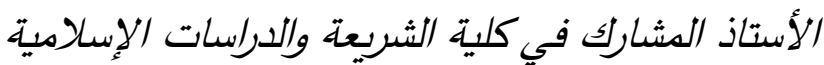 \\ بجامعة أم القرى بمكة المكترمة
}

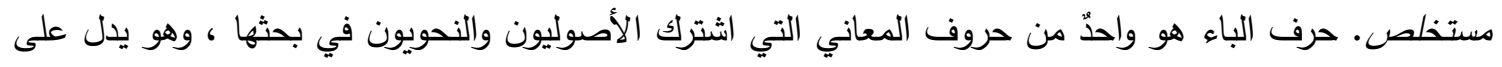

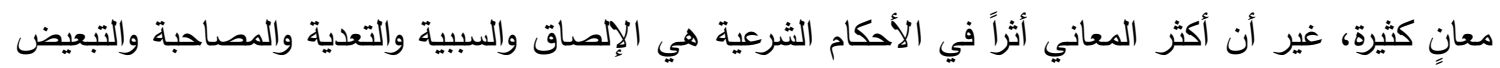

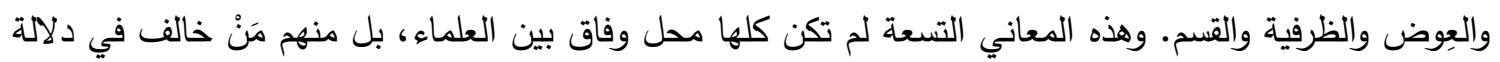
الباء على بعضها كالتبعيض، ووقع الإجماع على بعضها كالإلصاق. وترجّح لي صحة دلالتها على بقية المعاني.

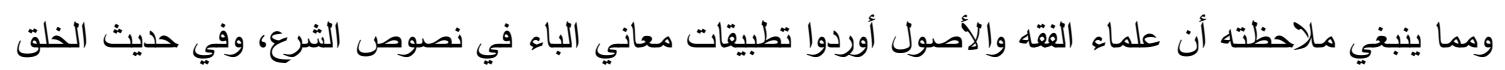

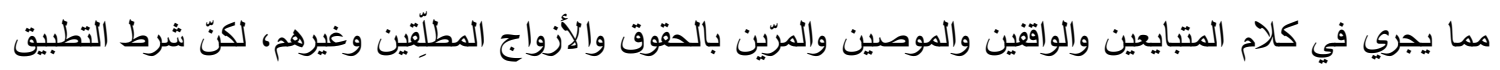

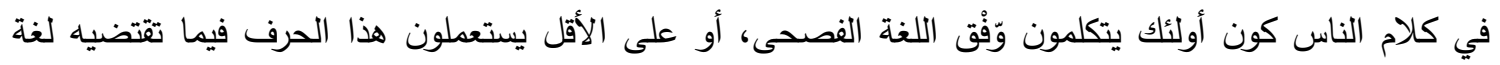

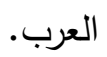

ومما ينبغي على طلاب العلم قبل الولوج إلى عالم

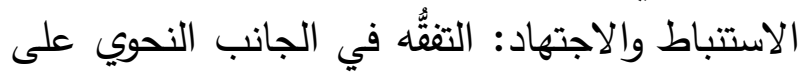
وجه الخصوص، وفي جانب اللغة على وجه العموم؛ فإتقان اللغة من أهم مفاتيح فهم الكتاب والسنة. ومن مباحث النحو التي عُنيَ بها الأصوليون:

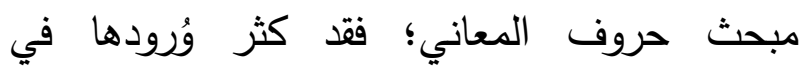
نصوص الوحيين، وشاع استعمالها على ألسنة فردان

\section{المقدمة}

الحمد الله رب العالمين، والصلاة والسلام على نبينا محمد الأمين، وعلى آله وصحبه والتابعين، وبعد: فقد انصبَّ اهتمام علماء الأصول على استتباط

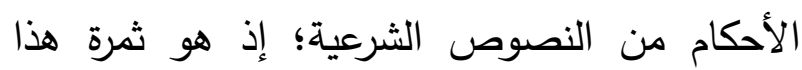

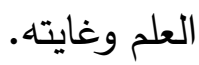




$$
\text { المبحث الأول }
$$

حروف المعاني ومنزلتها في أصول الفقه

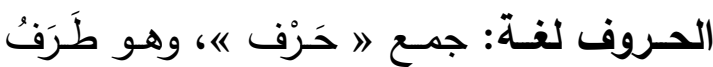

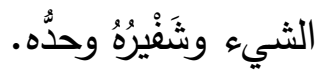

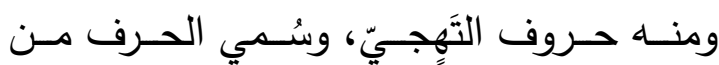

حروف الهجاء حرفاً؛ لأنَّهَ طرفت في الكلام (1).

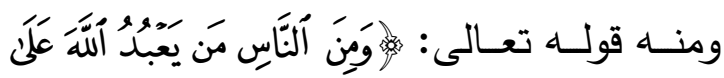

حَرْفِ يعبده على السَرَّاء دون الضّراء.

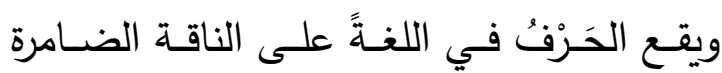

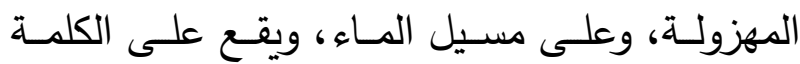

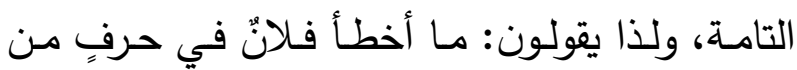
كلامه يريدون في كلمة منه (r)

والحرف اصطلاحا: هو ما دل على معنى في

وقيل: هو ما تتوقف دلالته على معناه الإفرادي

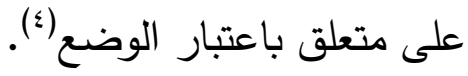

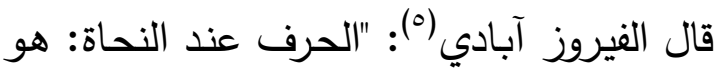

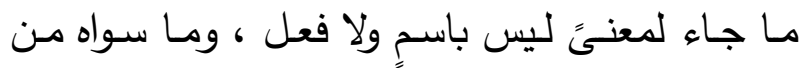

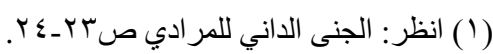

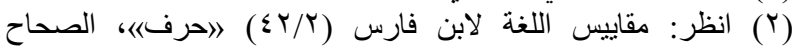

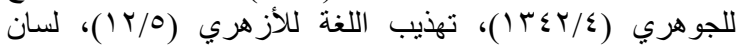

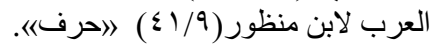

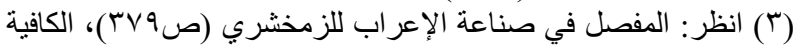

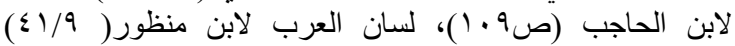

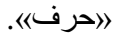

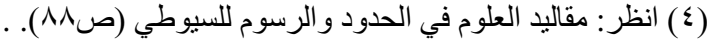

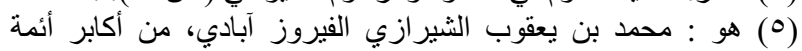

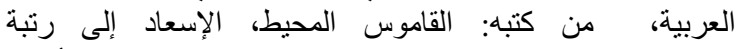

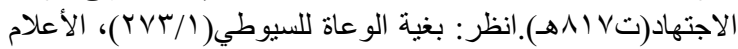

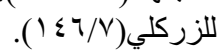

المكلفين، مما يوليها أهمية بالغة في استتباط الكثير

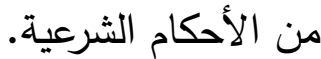
ومن أهم تلك الحروف: حرف الباء، وحيث لم أجد

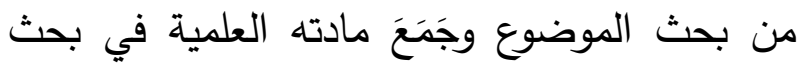

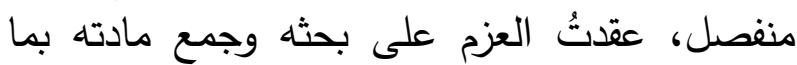
أرجو أن يفيد كاتبَّه وقارئَه.

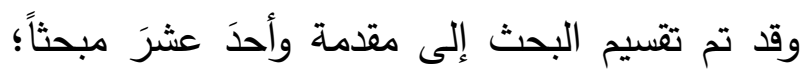

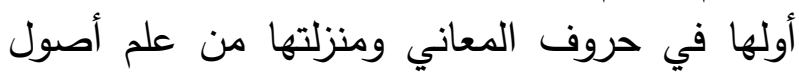

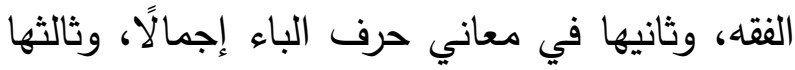
في دلالة الباء على الإلصاق وتطبيقاتها الفقهية، ورابعها في دلالة الباء على السببية وتطبيقاتها الفقهية، وخامسها في دلالة الباء على التعدية

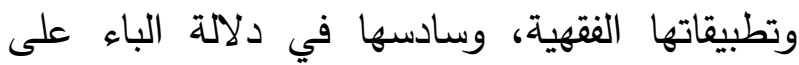

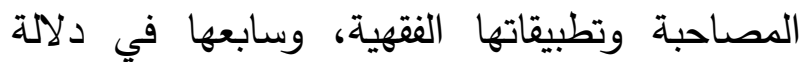

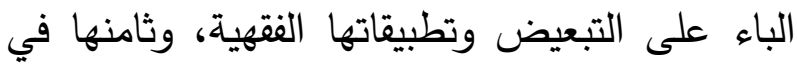
دلالة الباء على العِوَض وتطبيقاتها الفقهية، وتاسعها

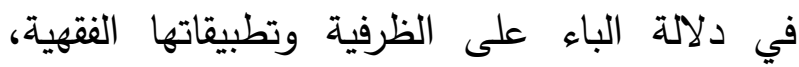

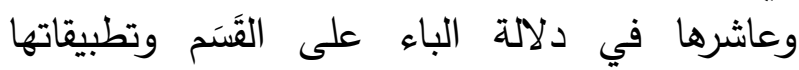
الفقهية، والحادي عشر في دلائلة النة الباء على الاستعانة وتطبيقاتها الفقهية، ثم الخاتمة والفهارس.

وقد اتبعت المنهج العلمي من كتابة الآيات القرآنية

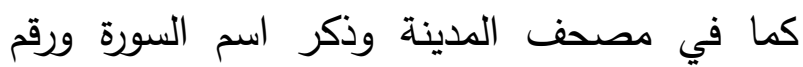

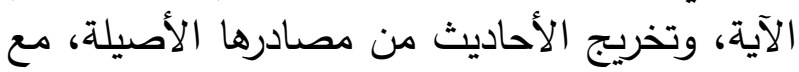

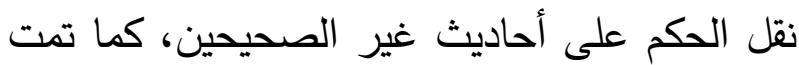
ترجمة الأعلام عدا الصحابة والأئمة الأربعة، وشرح الغريب، وتوثيق النقول في الهامش.

هذا وما كان في البحث من صواب، فمن فضل فيل فئ فئ

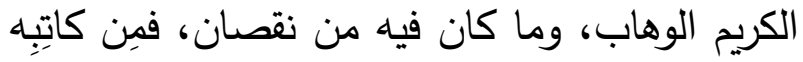

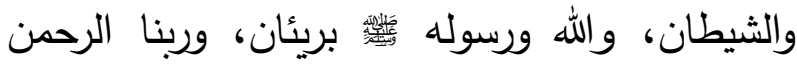
المستعان. 


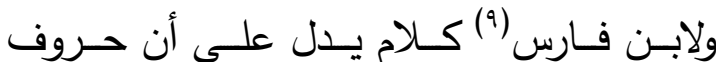

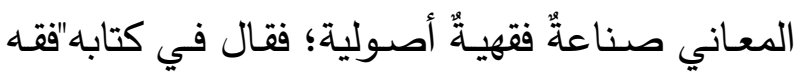

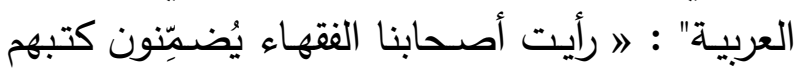

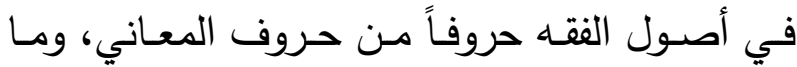

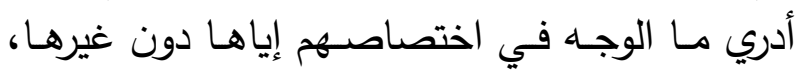

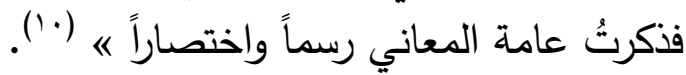
وحروف المعـاني مـن جملـة مـا استقاه علمـاء

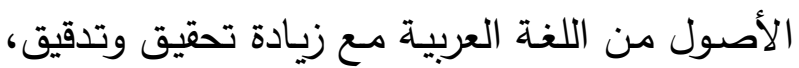

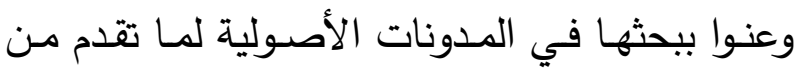

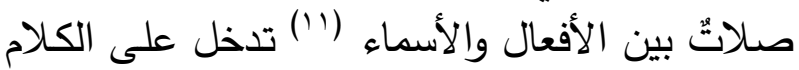

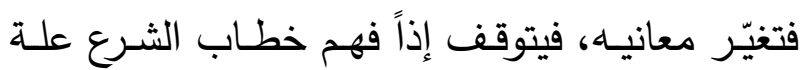

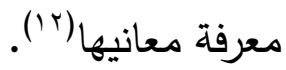

ولهـذا قـال بعـض الأصـوليين: إن شطراً مـن

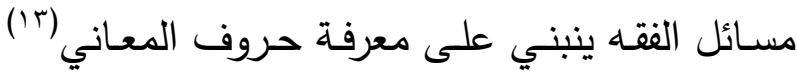

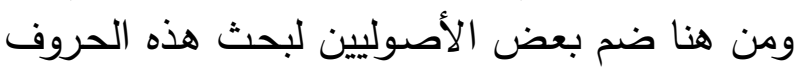
جملة من مسائل الفقه تخرّجت عليها؛ لتحصل الدربة لإنية

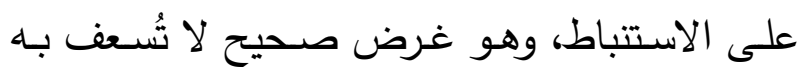

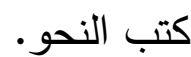

ويعرِفِ الأصوليون حروف المعاني عندهم فيقولون:

(9) هو أحمد بن فارس بن زكريا القزويني الرازي الثافعي، أبو الحسين، معنة

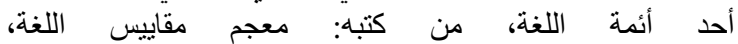

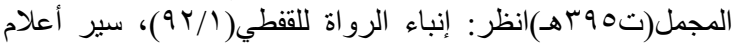

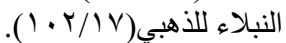

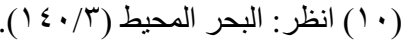

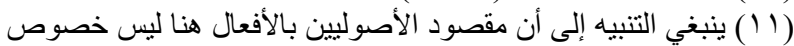

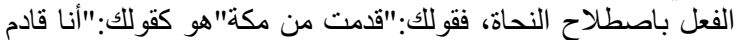

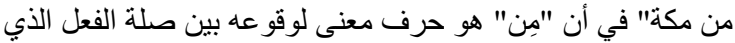

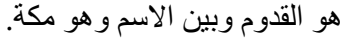

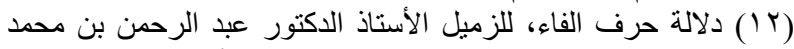

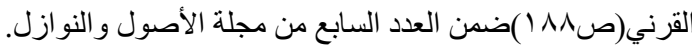

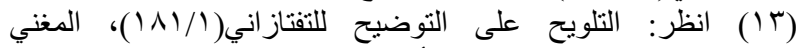

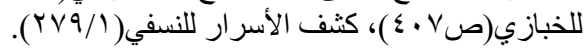

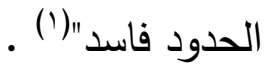

والمراد بحروف المعاني كما قال الباقلاني (؟):

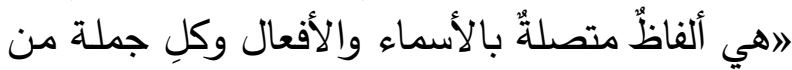

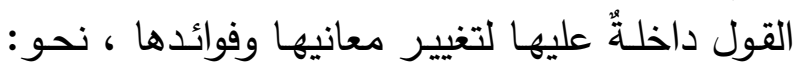

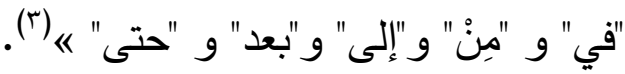

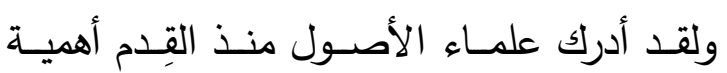

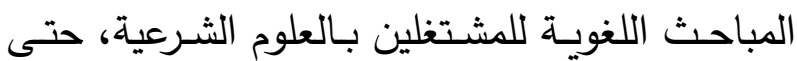

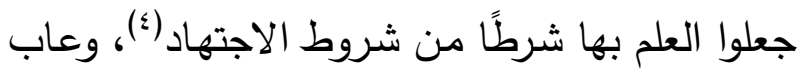

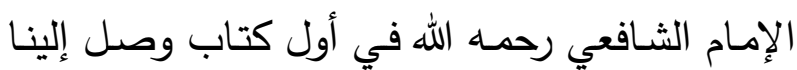
في أصول الفقه على من يتكلم في أحكام الشرع وهو الفول وهل

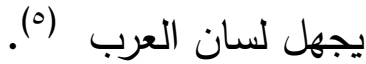

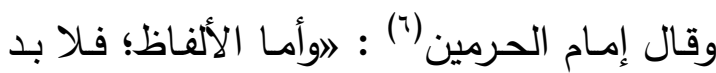
من الاعتناء بها؛ فإن الشريعة عربية، ولن يستكمل

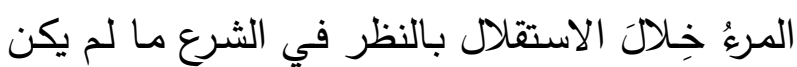

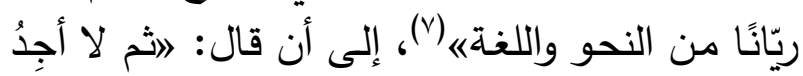

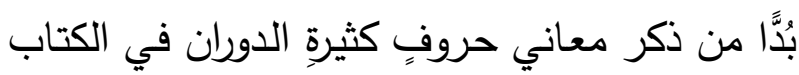

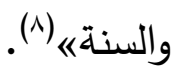

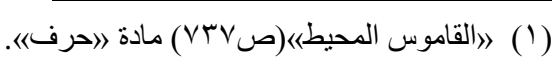

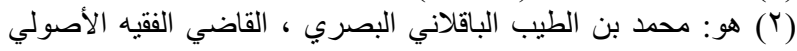

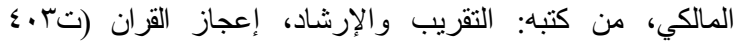

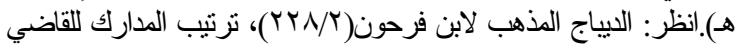
عياض ( ) (

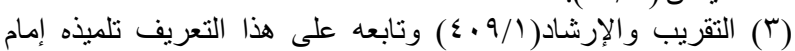

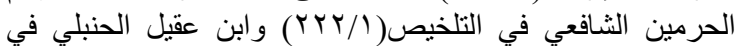

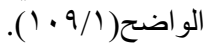

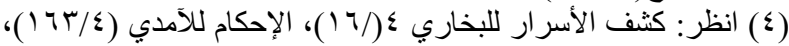

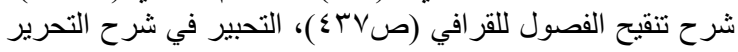

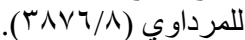

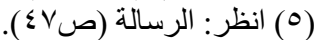

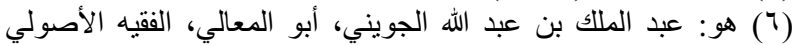

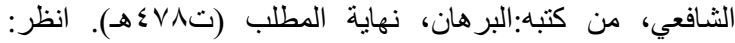

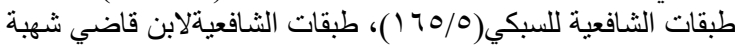
(ro0/1)

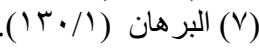

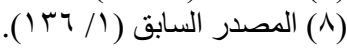


المحاسـن، جمـع بـين لطـائف النحـو ودقـائق الفتـه،

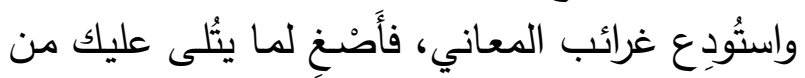
بيان لطائف حقائقه، واستمع لما يُلقى إليك من كشف

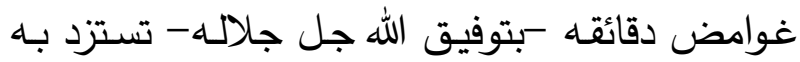
تبصراً في درك أسرار مستودعاته، وتستتفد به تبحراً في الوقوف على عجائب مستودعاته-إن شـاء الله سبحانه وتعالى -« (^).

\section{المبحث الثاني}

\section{معاني حرف الباء إجمالاً}

البـاء تكـون في كـلام العـرب مفـردة ومركبّة ، كونة

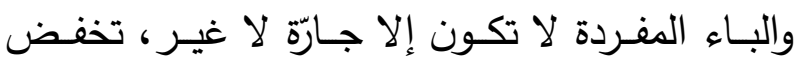

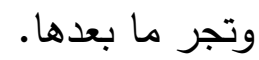

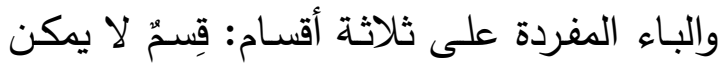

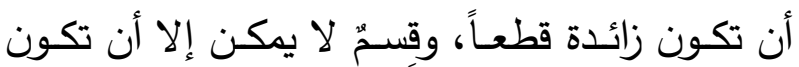

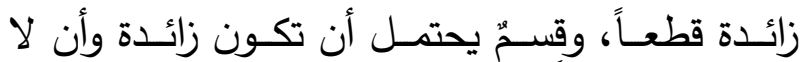

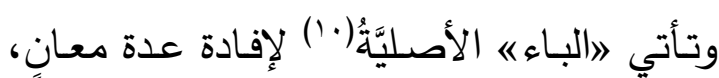

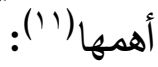

1- الإلصــاق: نحــو :"مررتُ بزيــد" أي التصـق مروري بالمكان الذي يلابسه. r- التعدية: نحو: ذهب يزيد.

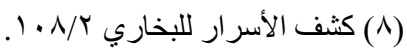

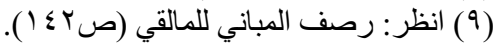

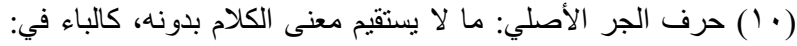

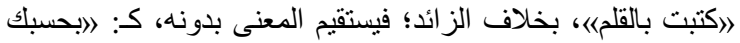

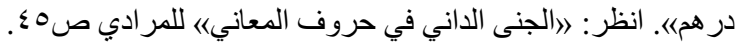

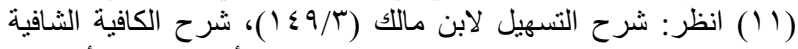

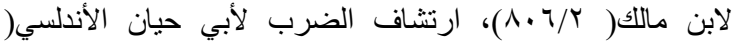

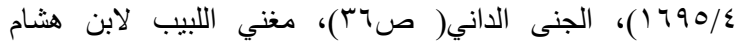

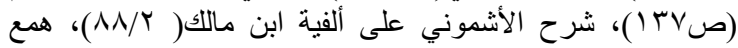

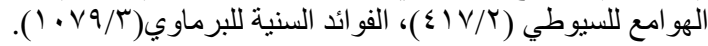

\section{هي ما تثتد حاجة الفقيه إلى معرفة معانيها (') .}

فلـيس مـرادهم خصـوص الحـرف باصــلاح

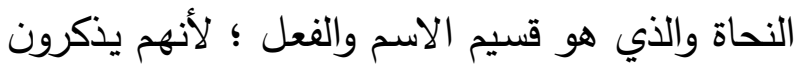

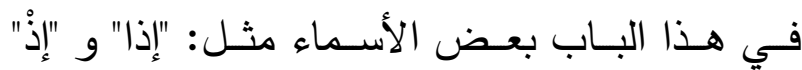

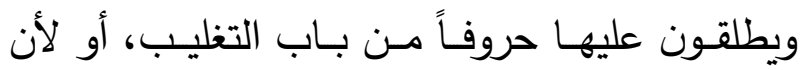

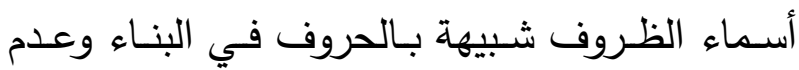

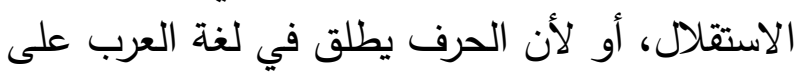

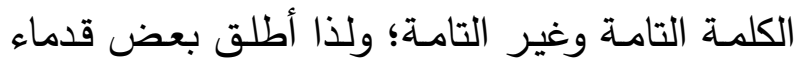

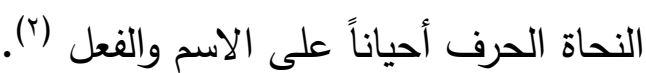

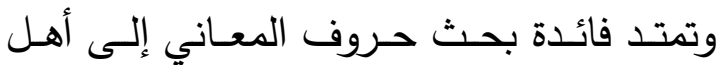

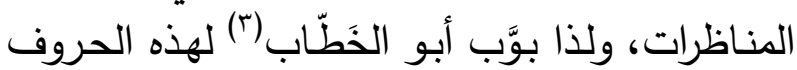
بقولهه: ״باب الحروف التي تجري بين المتناظرين،

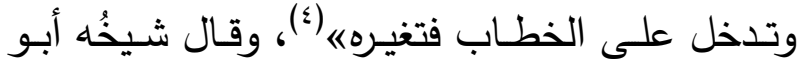

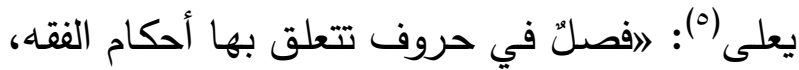
ويتنازع في موجباتها المتناظرانه(؟). وأختم أهمية الموضوع بعبارة بليغة لعلاء الدين

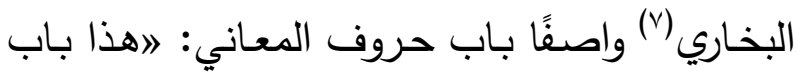

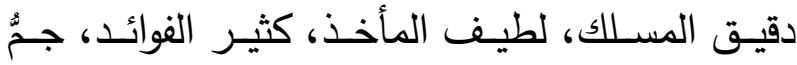

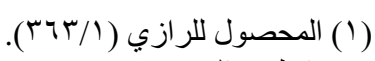

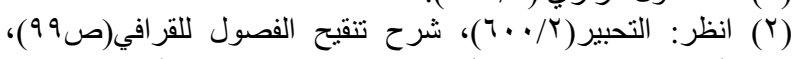

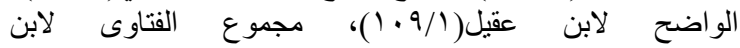

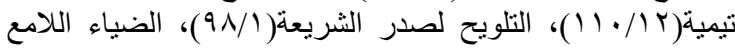

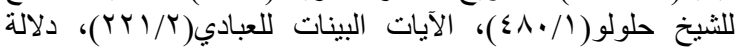

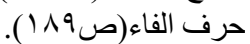

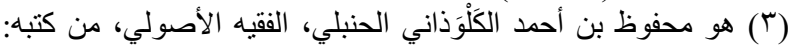

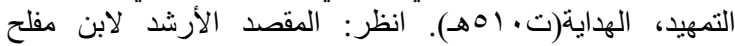

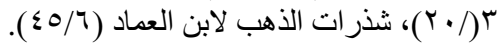
( ) التمهيد لأبي الخطاب (9/1) (9/1).

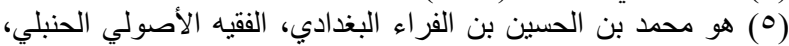

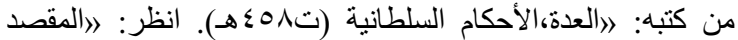

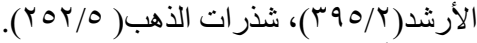

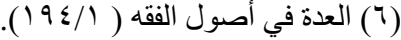

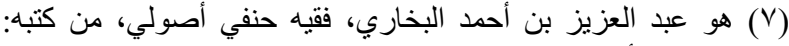

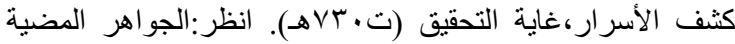

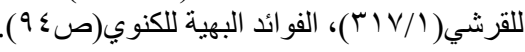


rا - التوكيد: وهي الزائدة، إما مع فاعل، نحو:

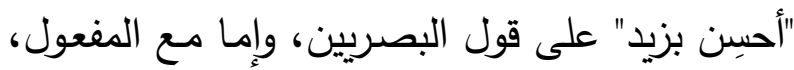

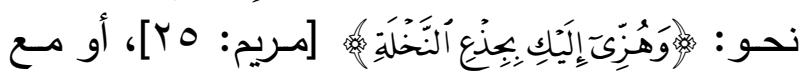

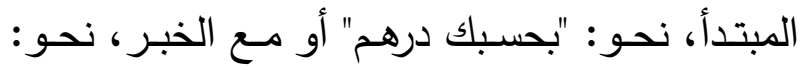

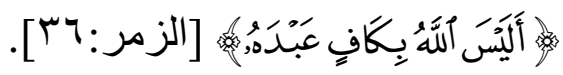

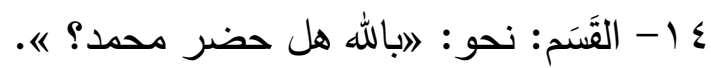
1 1 التعليق: نحو: "أنت طالقُّ بـخول الدار" أي: إنْ دخلت.

هذا؛ وقد وقع الخلاف في بعض هذه المعاني، كما أن بعضهم ذكر معاني أخرى ترجع عند التحقيق بعض هذه المعاني، إلى بعض المعاني المذكورة، كرجوع معنى المقابلة

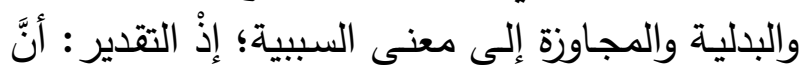
هذا بسبب هذا، وستأتي الإشارة إليه.

وسوف أقتصر في هذا البحث على أكثر معاني

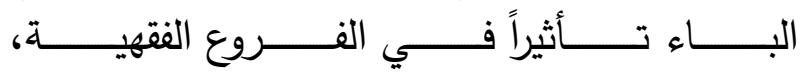

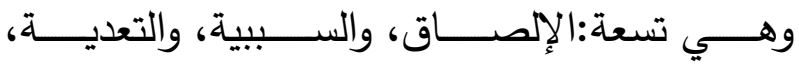

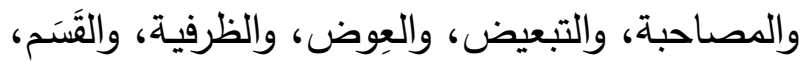

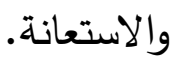

\section{المبحث الثالث}

\section{دلالة الباء على الإلصاق وتطبيقاتها الفقهية}

\section{المطلب الأول: معنى الإلصاق وأقسامه:}

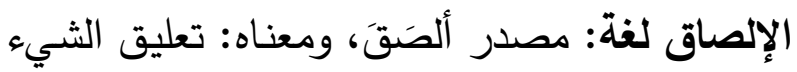

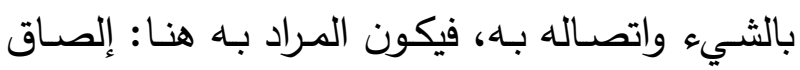

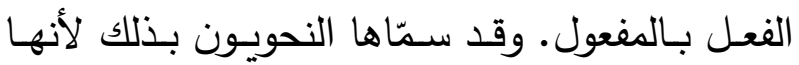

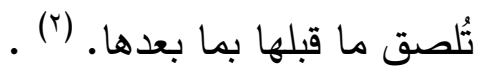

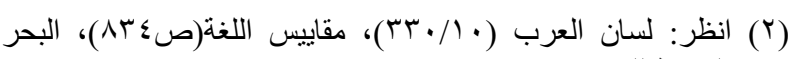

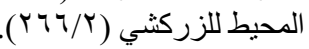

ب- الاسـتعانة، مثل : كتبـتُ بـالقلم، وقطعـتُ بالسكين.

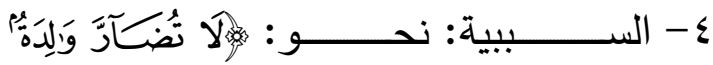

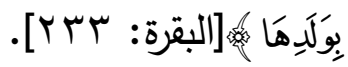

ه- الظرفيـة: أي بمعنـى (في) مثل:"جلســـ

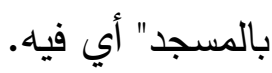

צ- المصــاحبة: أي بمعنــى( مــع)، ومنـــه:

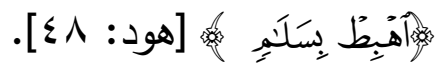

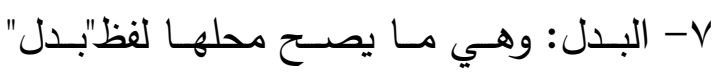

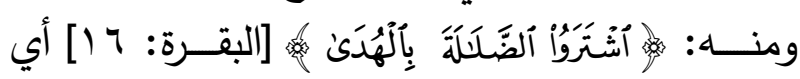
بدله.

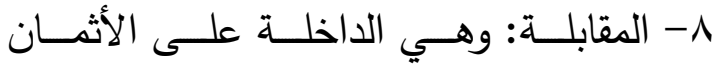

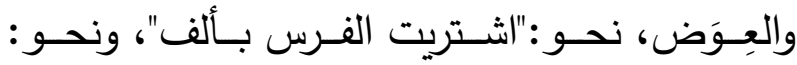

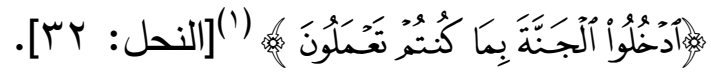

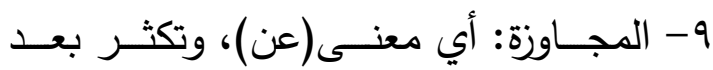

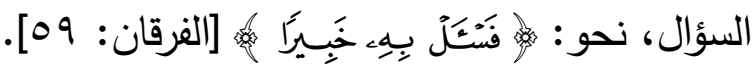
•

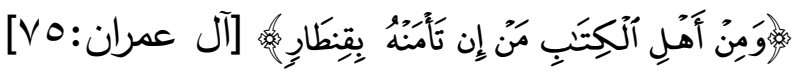
أي على قنطار .

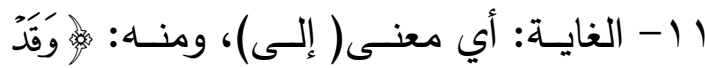

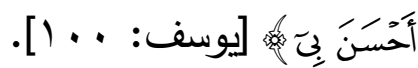

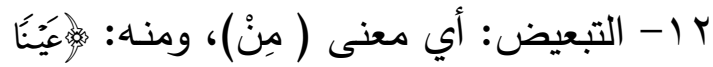

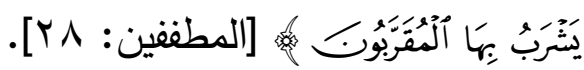

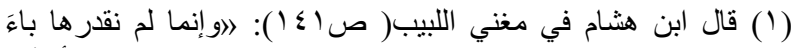

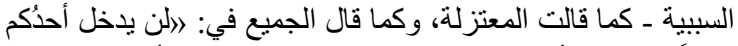

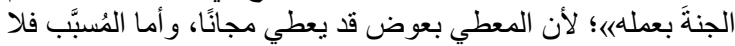

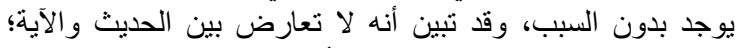
لاختلاف محملي الباءين؛ جمعًا بين الأدلةها. 
r-الاستعمال، فقد استعمل حرف (الباء) في

الكتاب والسنة، وفي كلام العرب الفصحاء وعند أهل

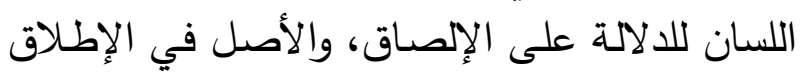

الحقيقة.

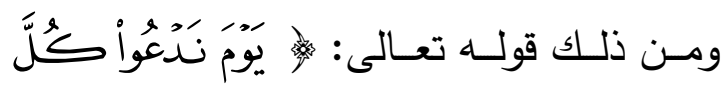

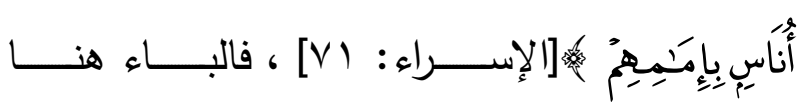
للإلصاق (๕). وغيرها كثير ، ومنه: ما ورد في الحديث في حكايـة وضـوي النبـي في : " فمسـح برأسـه مـرة

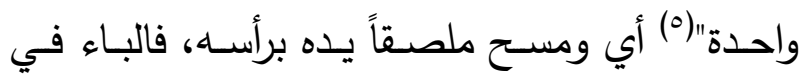
الحديث للإلصساق ومنـه قول الشـاعر : عَبَأتُ لـه

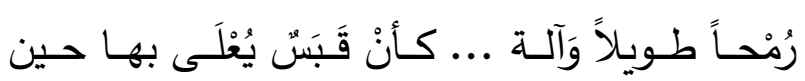

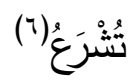

فهنا قد استعملت الباء في قوله: "بها"

لنإلصاق (v)

\section{*فوائد وتنبيهات:}

الأولى: عبّر سيبويه(^) عن باء الإلصاق بلفظ:

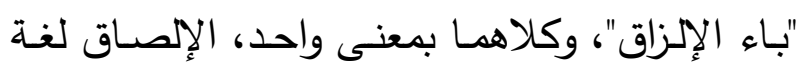

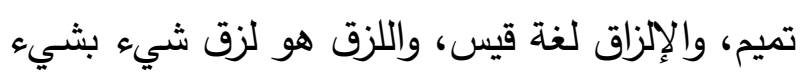

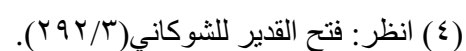

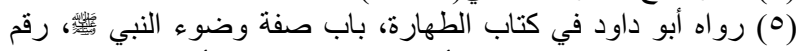

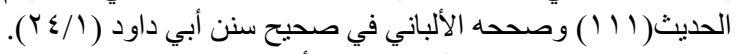

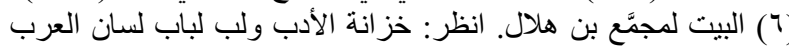

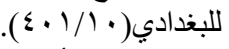

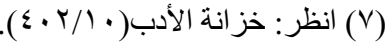

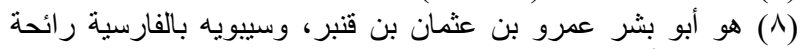

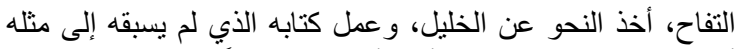

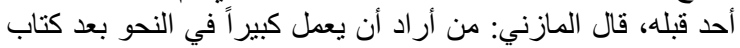

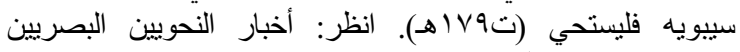

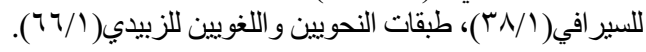

والإلصاق اصطلاحاً هو: أن يضاف الفعل إلى

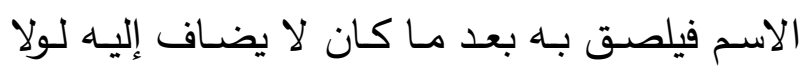

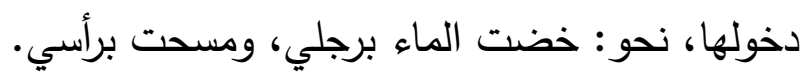
-هذا وقد قسّم الأصسوليون والنحساة الإلصـاق

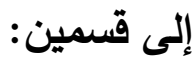
1- إلصـاق حقيقي: ويسـى أيضـاً بالإلصـاق

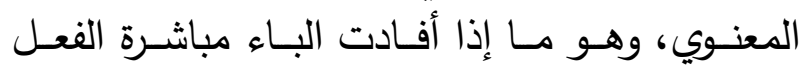

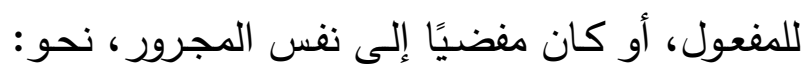

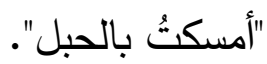

r-إلصـاق مجـازي: ويسـى أيضـاً بالإلصـاق اللفظي، وهو إذا كان الفعل لا يصل إلى مفعوله إلها

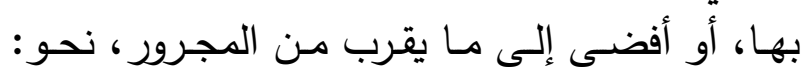

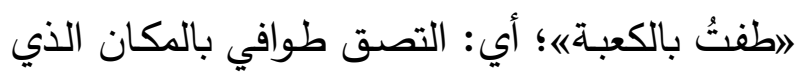

فيه الكعبة (')

وهذا المعنى -الإلصـاق - في البـاء في كـلام

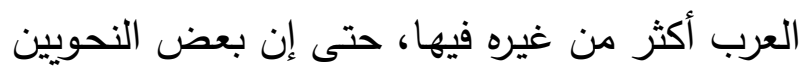

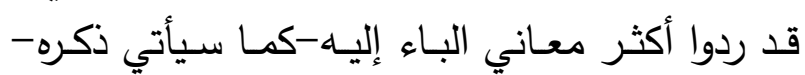
والصحيح التتويع وإفادة الباء غير معنى الإلصـاق

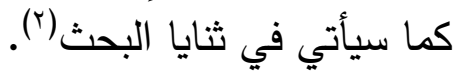
من الأدلة على إفادة الباء للإلصاق: لئل

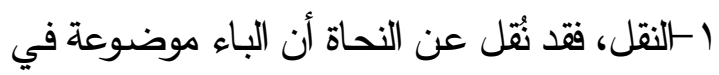

أصل اللغة للإلصاق، وقول النحاة حجة (؟).

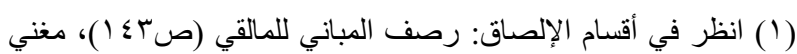

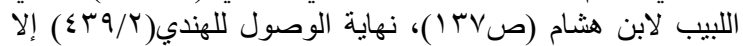
أن المالقي سمى القسمين: لفظياً و معنوياً .

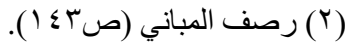

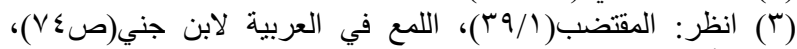

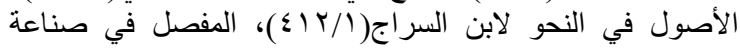

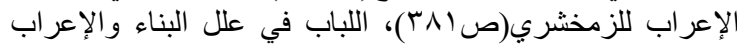

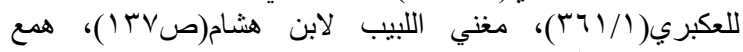

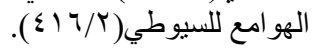


وذهب البعض إلى أن الباء مشترك(^) يدل على مهى

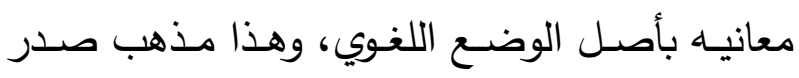
الشريعة الحنفي (9) أصني الون

والراجح هو الأول ويدل عليه استعمال العرب

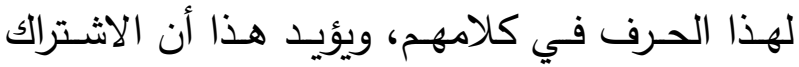
خلاف الأصل، فحمل الحرف على الإفراد أولى. معنى لا يفارق الباء، ولهذا لم يذكر سييويه

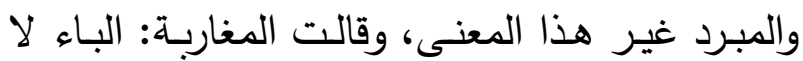

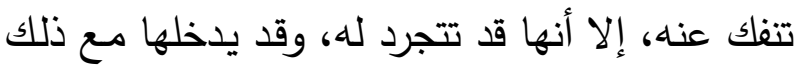

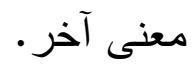

الثالثة: قال الرازي (·) "): " وأجمعنا على أنها-أي

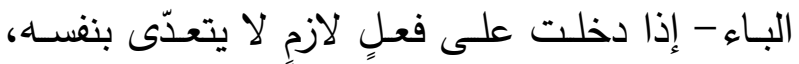

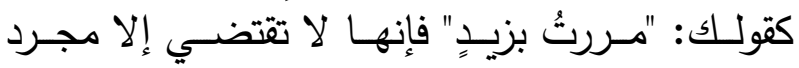

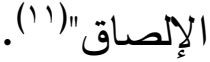

\section{المطلب الثاني: تطبيقـات فقهيـة لالالـة البـاء}

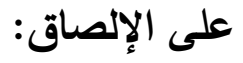

المسألة الأولى : استدل الحنابلة بقوله تعالى:

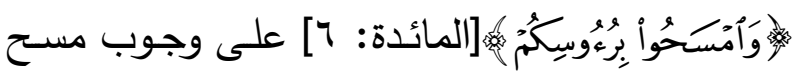
جميع الرأس في الوضوء؛ لأن الله تعالى ربط الفعل

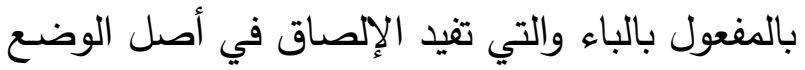

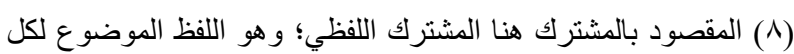

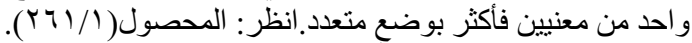

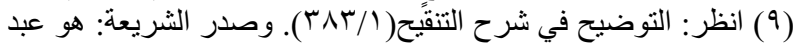

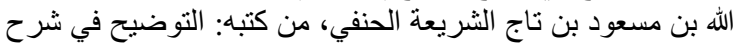

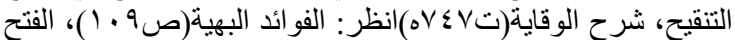

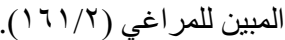

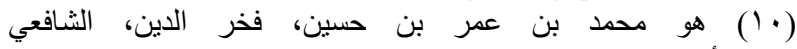

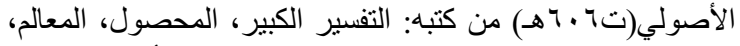

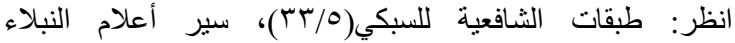

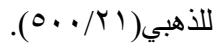

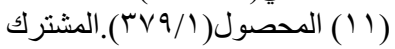

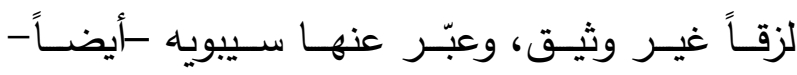
بباء الاختلاط' ل). قال سيبويه: " وعبر وباء الجر إنما هي

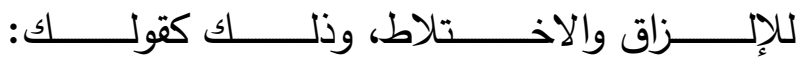

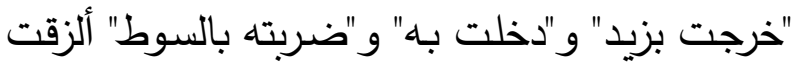

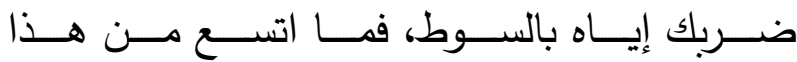

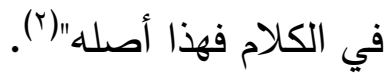

الثانيـة: أن أصلـ معنى البـاء الإلصـاق، ومـا

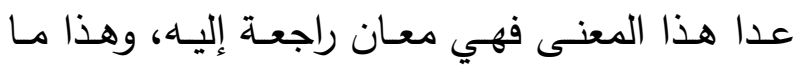

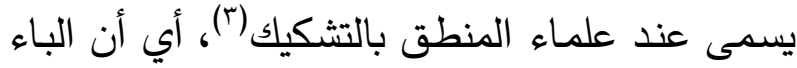

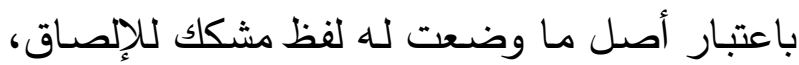

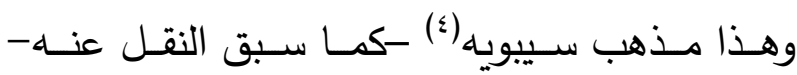

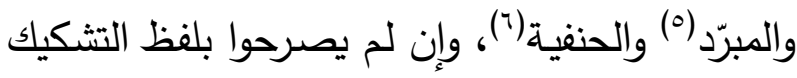

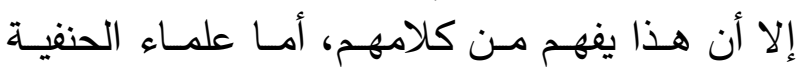

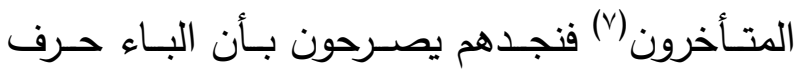
مشكك للإلصاق بأصل وضعده اللغوي.

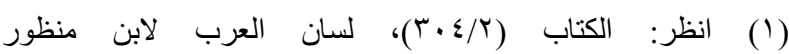

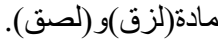

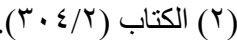

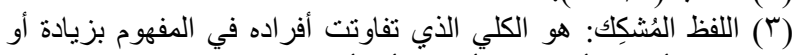

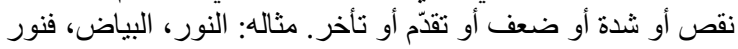

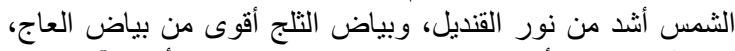

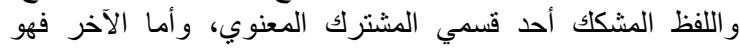

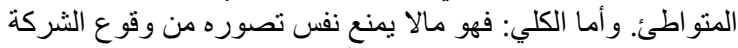

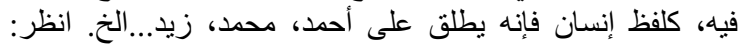

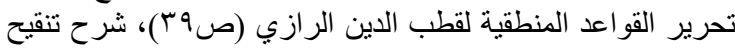

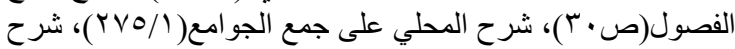

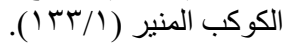

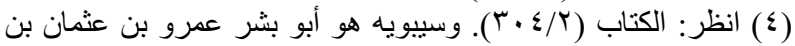

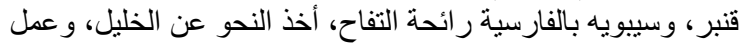

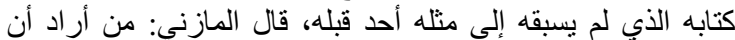

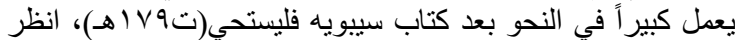

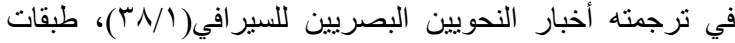

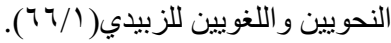

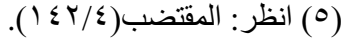

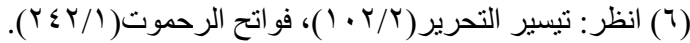

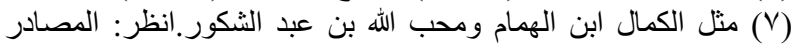
السابقة. 


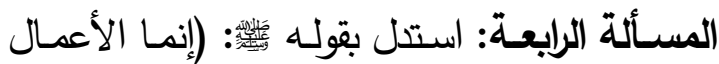

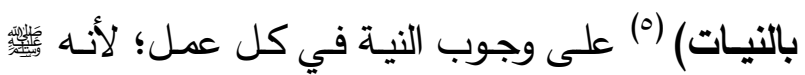

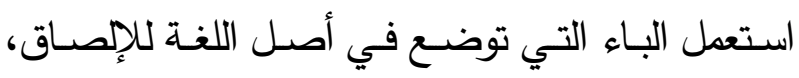
فيكون المعنى: كل عمل تلتصق به نيته(؟). المســألة الخامسـة: يستـل بمـا ورد عـن ابن

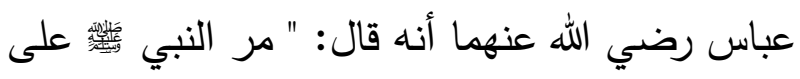
رجل قد خضب بالحنـاء، فقال: "ما أحسن هذا"(V)؛ على جواز الخضاب وصبغ الشعر بالحناء للرجال؛

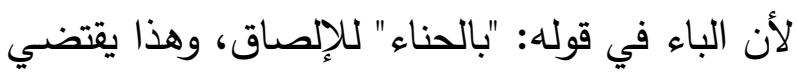

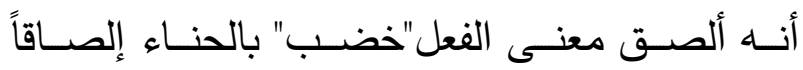

حقيقياً (^).

المسـألة السادسـة : لو قال رجل لزوجتـه: أنت

طالق بمشيئة الله، أو بإرادته، ونحو ذلك؛ لم تطلق؛ لأن

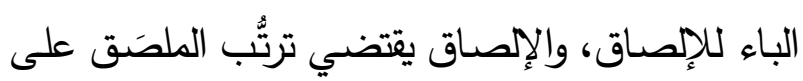
الملصَق به في الزمان، ولا وجود لذلك (9). المسألة السـابعة : لو حلف رجل على امرأته وقال: لا تخرجي إلا بإذني، فإنـه يجب لكل خروجٍ

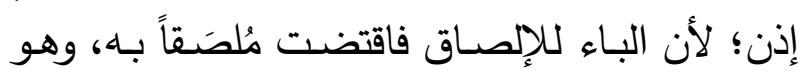
الخروج، فلو خرجت مرة بغير إذن حنث.

(0) رواه البخاري في المقدمة، باب بدء الوحي، رقم الحديث( (1)، ورواه

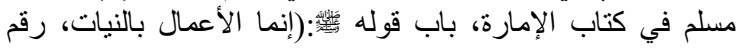

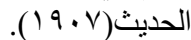

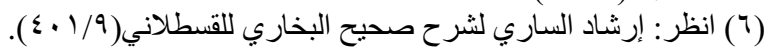

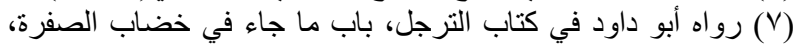

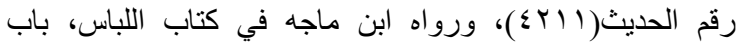

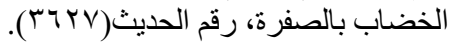

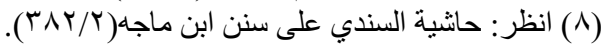

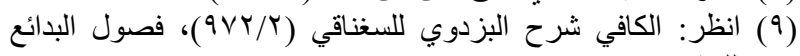

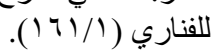

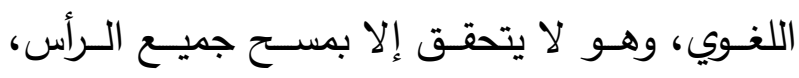

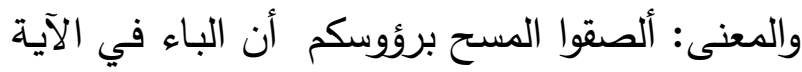
للإلصاق؛ أي: إلصاق الفعل بالمفعول، فتقدير الآية:

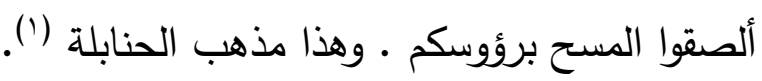

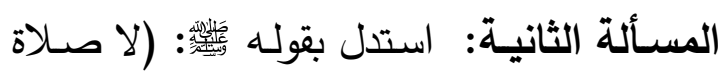
لمن لم يقرأ بفاتحـة الكتـاب) (广) على وجوب قراءة

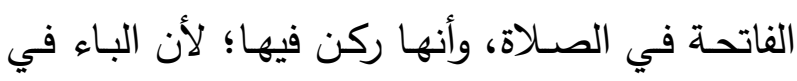

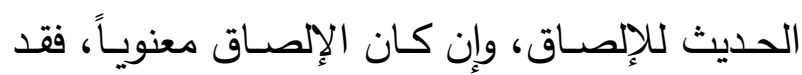

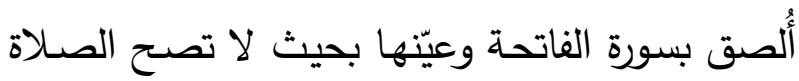

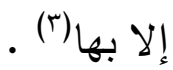

المســـألكة الثالثـــة: اســتـل بقولـــه تعــالى:

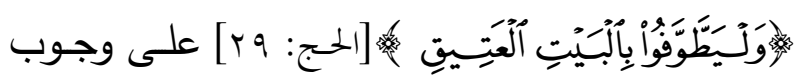

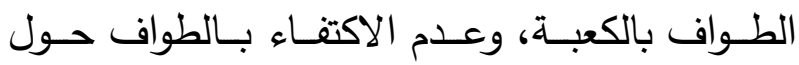

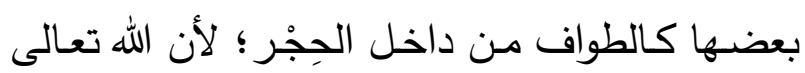

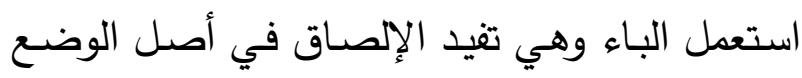
اللغوي، فيكون المطلوب هو إلصـاق الطواف بها، بالطواف حولها كلها(ء).

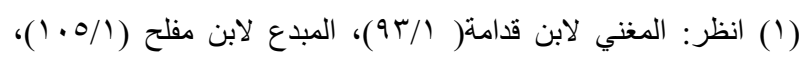

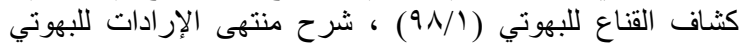

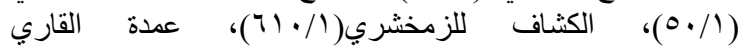

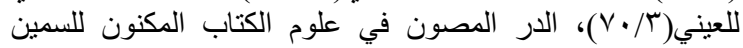

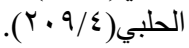
(Y) رواه البخاري في كتاب الأذان، باب وجوب القراءة للإمام والمأموم

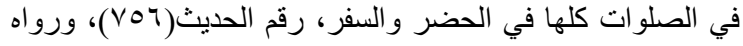

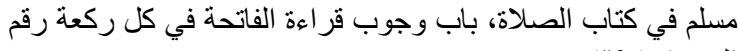

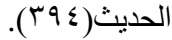

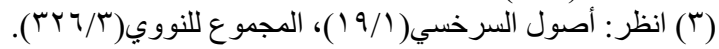

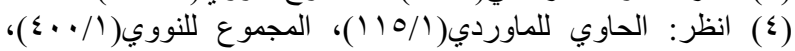

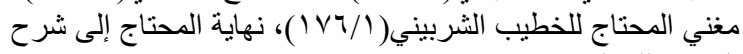

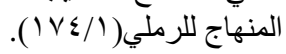


أنواع) ثم ذكر هذه الأنواع وهي: التعدية، والسببية، والاستعانة، والمصاحبة، والظرفية، والقسمية (ه).

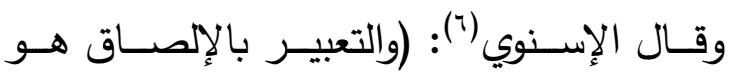
الصواب، ولم يذكر سيبويه للباء معنى غيره، ويدخل

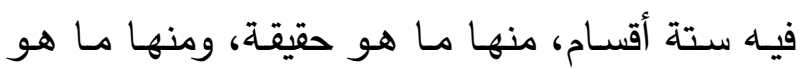
مجاز ، كما هو معروف في كتب النحو)(vi). وقـال نجـم الـدين الطـوفي (^)عن (الإلصـاق): (وهـو معناهـا العـام، لرجـوع سـائر معانيهـا إليــه، ووجـوده في جميعها، نحـو كتبـت بـالقلم) (9)، ويـرى ملع بعض العلماء أن الصحيح هو التتويح، وليس معنى الباء قاصراً على الإلصاق(·') وسوف أشرع في ذكر أهم المعاني التي يفيدها حرف الباء، وبالله التوفيق.

\section{المبحث الرابع}

\section{دلالة الباء على السبيبة وتطبيقاتها الفقهية}

$$
\text { المطلب الأول: معنى السببية: }
$$

السـببيِة لغـةة: نسبة إلـى السَبَبِ وهـو الحَبْل،

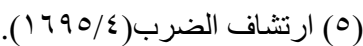
(7) هو عبد الرحيم بن الحسن الإسنوي، أبو محمد جمال الدين، الإمام

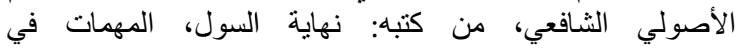

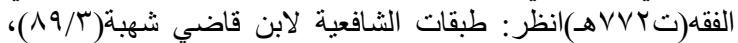

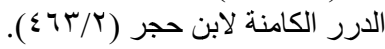

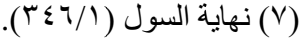

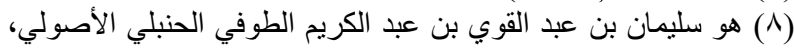

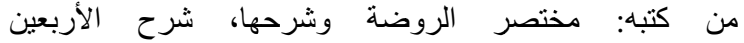

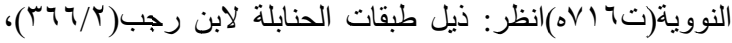

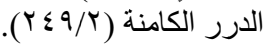

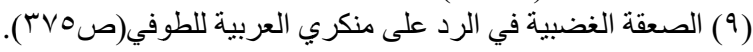

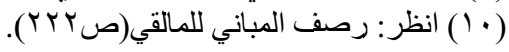

ولـو قـال لامرأتـه: إنْ خرجتِ مـن الـار بغيـر

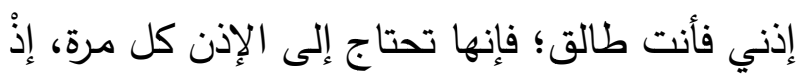
المستثنى خروج ملصق بالإذن، فلو خرجت في المرة الإنه الثانية بدون الإذن طلقت ('). المسـألة الثامنـة : لو قال لامرأته: أنت طالقُ بحيضتك؛ لم تطلق حتى تحيض؛ لأن الباء حرف البه إلصـاق فيقتضـي إلصـاق الطـلاق بالحيضـة، فيتعلق لانق

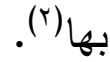

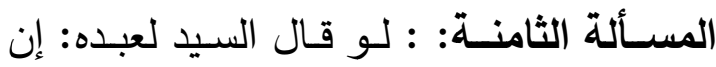

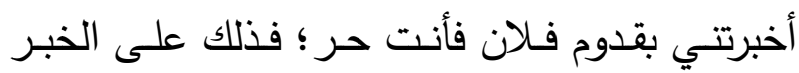

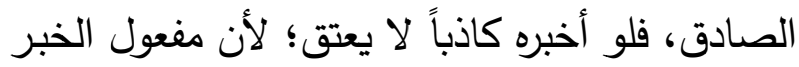

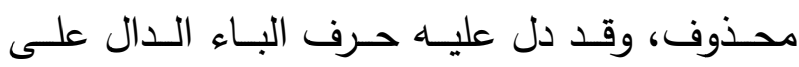
الإلصاق، فيكون معنى كلام السيد: إن أخبرتني خبرًا

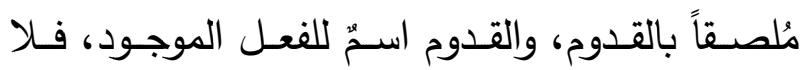
يتتاول الخبر بالباطل، ولو قال: إنْ أخبرتني أنَّ فلانًا قَدِم فأنت حر ؛ فذلك على مطلق الخبر ، فلو أخبره كاذباً عَتَق (")

هذا، ولمـا كـان الإلصـاق هو المعنى الحقيقي للباء -ولذا أطلت فيه- وبقية المعاني راجعة إليه، كما

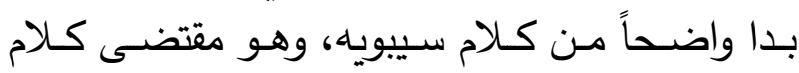

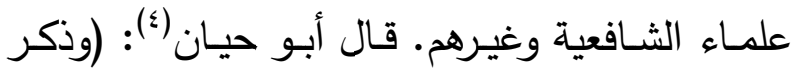

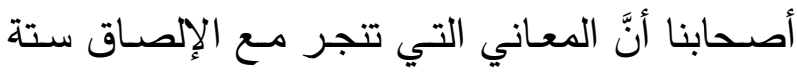

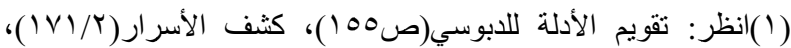

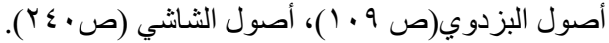

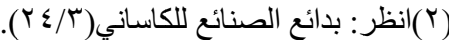

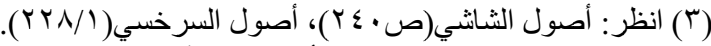

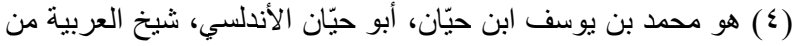

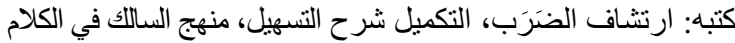

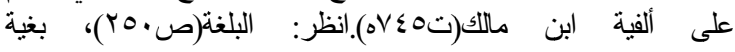

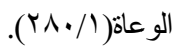


اليهـود بظلمهـ؛ جـاز مجـازاً أن يقـال: حسَّم

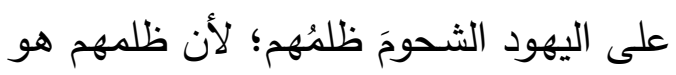

$$
\text { سبب التحريم، وهو مجرور " الباء". }
$$

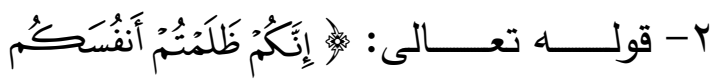

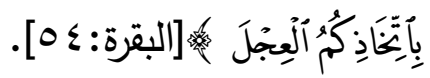

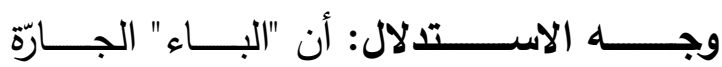

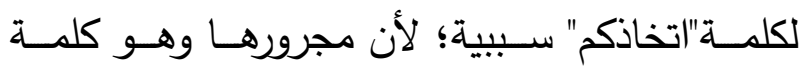

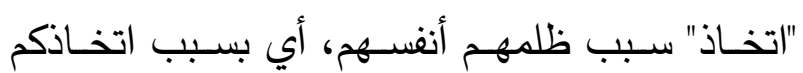

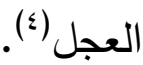

\section{فوائد وتنبيهات:}

1 ـ يعبّر البعض عن باء السببية: بقولهم: باء

التعليل (0).

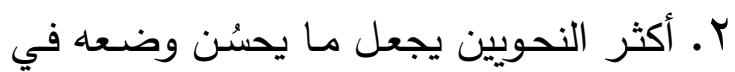

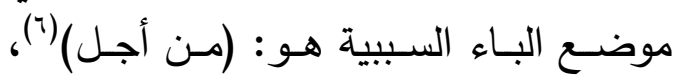

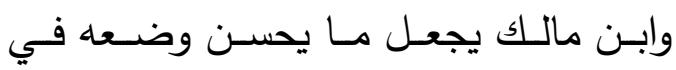

موضعها غالباً هو (اللام) باعتبار أن الباء

للتعليل (v)

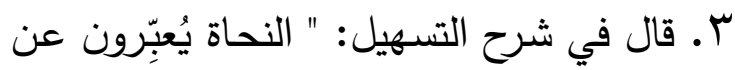

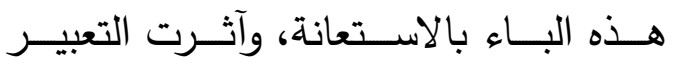

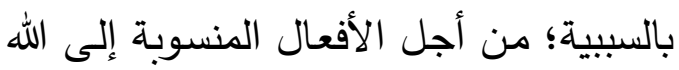

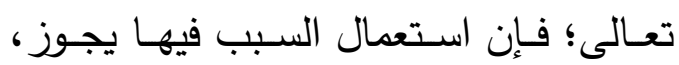

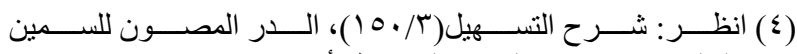

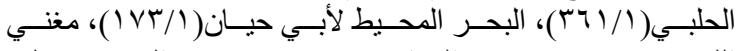

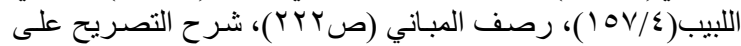

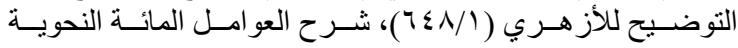

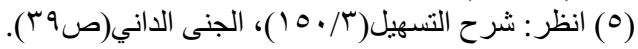

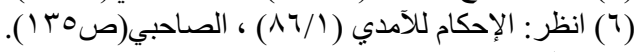

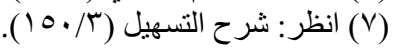

ويطلق السبب -أيضاً - على كل شيء يُتوضَلُ به

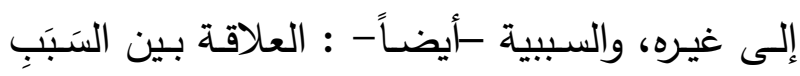

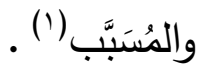

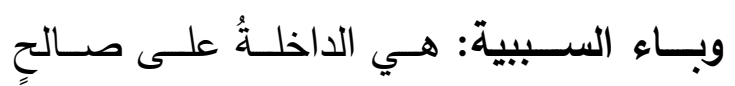

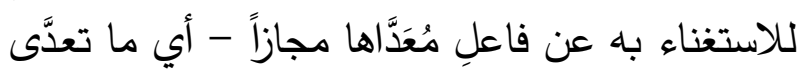
بها وهو ما تعلّقت به من فعلٍ أو شبهه - نحو قوله تعــــــالى

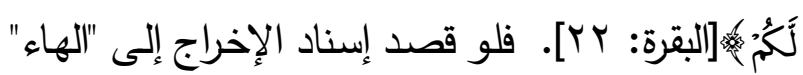

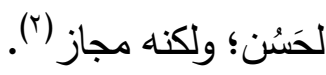

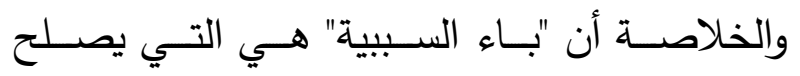
مجرورُها لأن يكون فاعلاً مجازاً مكانَ فاعلِ مُتعلَّقها

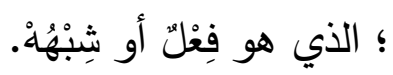

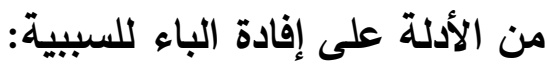

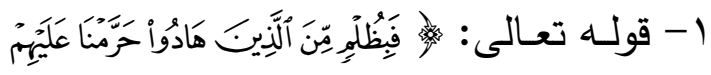

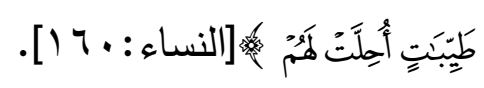

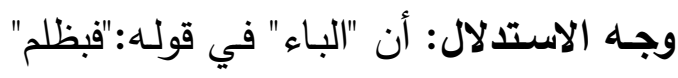

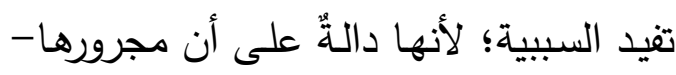
وهو الظلم- سبب تحريم طيباتٍ عليهم قد الند

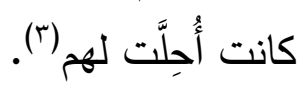

وطالما أن "باء السببية" هي التي يصلح مجرورُها لأن يكون فاعلاً مجازاً مكانَ فاعلِ لَّل

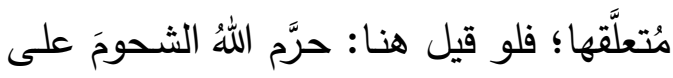

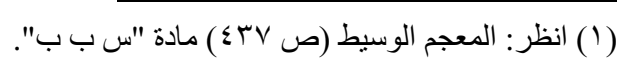

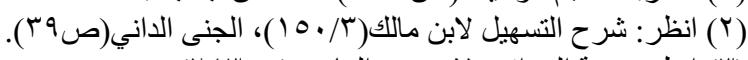

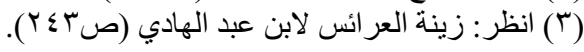


ه- اسـتل على منـع أنْ يكون المهر منفعـة،

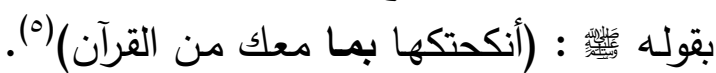
وجـه الالالـة: أن البـاء في قولـه: (بمـا معك) للسـببية، وهـو قـول الحنفيـة، فيكـون المعنـى تكريمه بالزواج بسبب ما معده من القرآن، قالوا: ولعلها وهبت صـداقها لذلك الرجل كمـا وهبـ

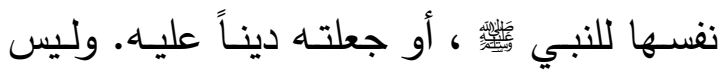

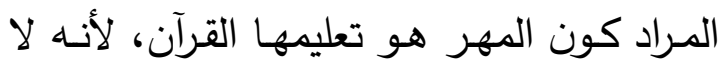

يجوز أن يكون المهر منفعة(؟).

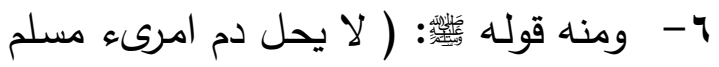

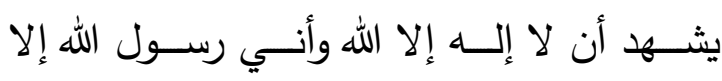
بإحدى ثـلاث: النفس بالنفس، والثيب الزاني،

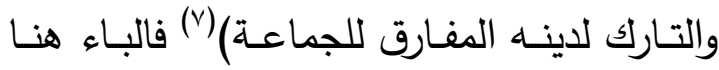
للسـببية أي ارتكــاب إحـدى الجـرائم الثــرعية الثلاث (^).

- V الأعمال بالنيات)(9) فالباء في قولهه: (بالنيات)

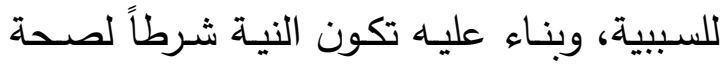
العبادة، والشرط لا يجب مقارنته ولا اتصاله ولا

(0) رواه البخاري في كتاب النكاح، باب وكالة المر أة الإمـام في النكاح،

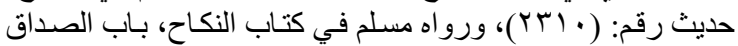

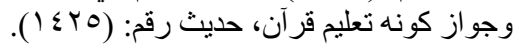

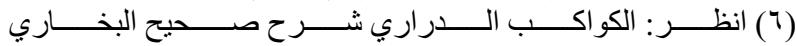

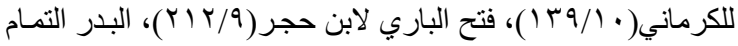

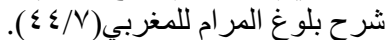

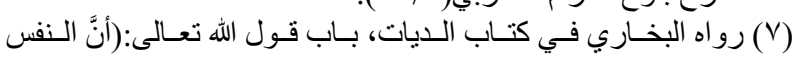
بالنفس) حديث رقم: (1) (1) () ).

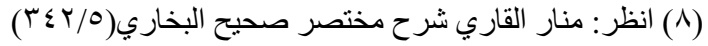

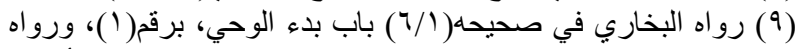

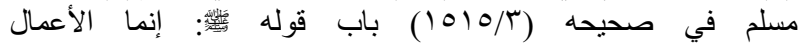
بالنية،برقم(V • 9 ( ) كلاهما من حديث عمر بن الخطاب رضي الله عنه.
واستعمال الاستعانة لا يجوز " (').

المطلب الثاني: تطبيقـات فقهيـة لالالـة البـاء

على السببية:

1-استدل بقول النبي

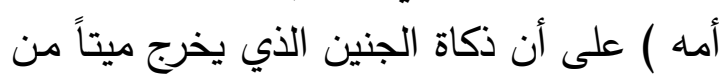
بطن حيوان مأكول بعد ذكاته، حاصلة في ذكاة أمه بشرط كمال خلقه؛ لأن الباء للسببية، وهذا

مذهب المالكية)(r). r- البـاء فـي قـول النبـي

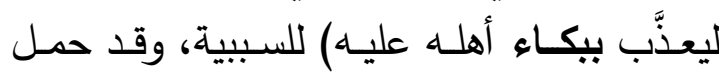
جمهـور العلمـاء الحـديث على حسال توصـية

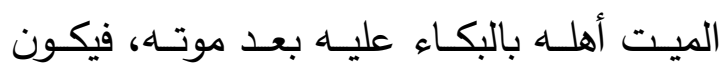

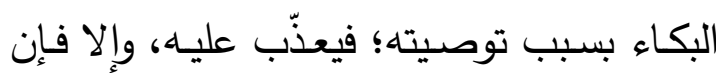
أصل البكاء على الميت جائز من غير ندب ولا لوابه نياحة (r). ب- اسـتل بقـول النبـي بنفقته إذا كان مرهوناً، ولبن الدر يشرب بنفقته

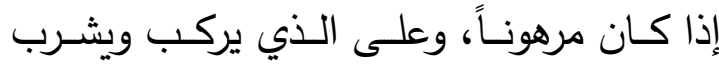

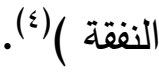

ع - وجـه الاستـدلال: قولـه: (بنفقتـه) فالباء هنـا يُحتمـل أنها للسببية، فـإذا جعلناهـا للسببية فيجـوز للمرتهِن أن يأخذ أكثر من النفقة.

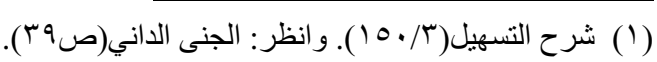

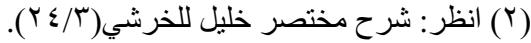

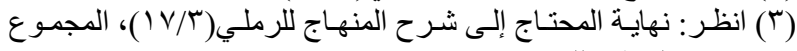

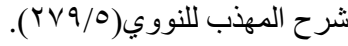
(ع) رو اه البخاري في كتاب الرهن، باب الرهاب الرهن هن مركوب ومحلوب، حديث

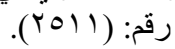


للسببية كما في الوجه الأول، أو للظرفية أي :

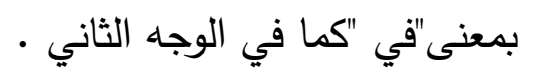
مسألة في "الباء " المترددة بين السببية والظرفية : حكم من قال : وققتُ هذا بهذا ، فإن أراد أن هذا سبب وقف هذا ؛ ؛ لم يصر وقفاً، وإن أراد "في" صار وقفاً (V). المبحث الخامس

دلالة الباء على التعدية وتطيقاتها الفقهية المطلب الأول: معنى التعدية: التعديــة لغــة: مــأخوذة مـن التعـدّي، وهـو

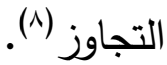

والتعديـة اصــطلاحاً: هـي تعديـة الفعـل إلى المفعول به، فإذا كان الفعل لا يتعدى إلى المفعول

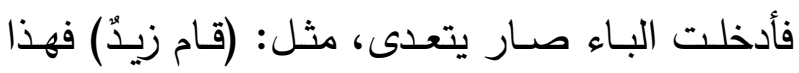

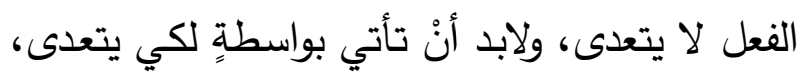

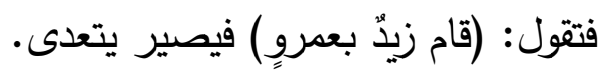
وبــاء التعديـة: هـي القائمــة مقـام الهمـزة فـي إيصال معنى الفعل اللازم إلى مفعوله(9). وبعبارة أخرى: هي الباء التي تدخل على فعلٍ لا يتعـدّى؛ فتجعلـه يتعـديّ بنفسـهـ، وبــنلك تُصـيّر

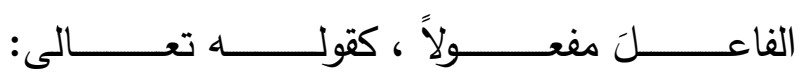

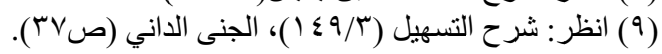

تكراره للمشروط(') - ت

1- اشـترط جمهـور الفقهــاء خلافـاً للحنفيـة التقابض في بيع الطعام بالطعام؛ لأن قوله

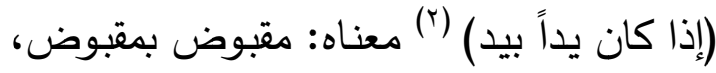
فعبّر باليد عن المقبوض؛ لأنه من باب التعبير ليدان

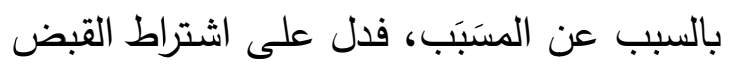

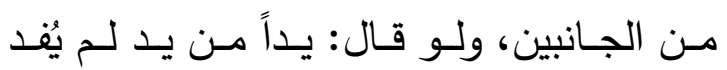
ذلك (r). 9- أن فوائــــ المبيـع يملكهـا المشـتري بسـبب ضمانه للبيع إذا تلف؛ لدلالة الباء على السببية

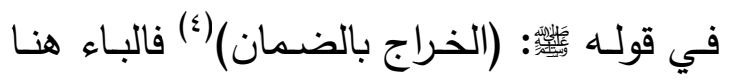
للسببية (0). • 1 - إذا قال لامرأته: إنْ عصيتِ بسفركِ

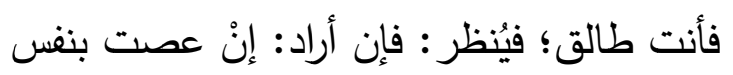

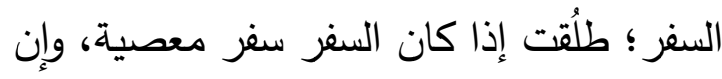
لم يرد نفس السفر ، لكنه أراد معصيتها فيه؛ لم لم تطلق بالسفر ، وإنما تطلق بالمعصية بالسفر (؟). وهذه المسألة تُبنى على قاعدة: أن "الباء"

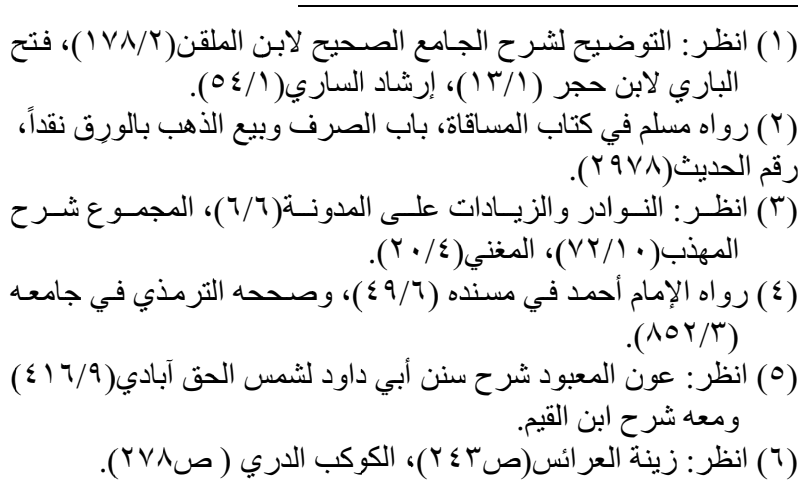


ضَرَب زيدٌ عمراً، وقَتَل خالداً العقرب (๕). ثانيـاً: الفعـل غير المتعدي: وهو الـلازم، وهو الفعل الذي لا يتجاوز الفاعلَ إلى محل غيره، بمعنى

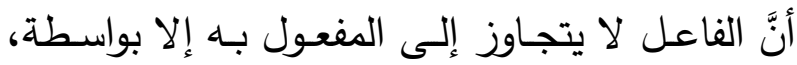
نحـو : (قـام)، وَ(ذهـبـ)، فتقـول: قـام زيـدُ، وذهـبـ عــرؤ (')، ولا تسـتطيع أنْ تــأتي بـالمفعول بـهـ إلا بواسطة.

ب-هل معنى التعدية في الباء حقيقي؟:

جعل إمـامُ الحـرمين التعديـةَ حكمـاً مـن أحكـام الإلصـاق، فقـال فـي كـون الإلصـاق هـو المعنـى الظاهر من الباء: (ومن أحكامه تعدية الفعل الـلزم)

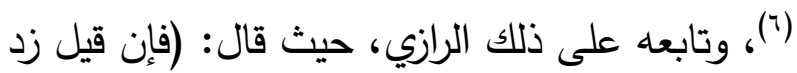
بياناً ؛ فإنَّ الباء في الحقيقة للإلصـاق، فكيف يُفهم معنى الإلصاق في هذه المواضـع؟ نقول: التعدية قد تتحقق بالباء، يقال: (ذَهَبَ بزيدٍ) على معنى ألصق الذهاب بزيد، فوجد قائماً به، فصار مفعولاً)(V). المطلب الثـاني: تطبيقـات فقهية لالالـة البـاء على التعدية: 1-اسـتـل بعـض الفقهـاء بقــول النبـي (أسـفروا بــالفجر ) علـى اسـتحباب الإسـفار بصلاة الفجر • وهو مذهب الحنفية. قالوا: الباء

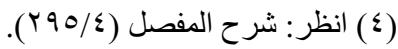

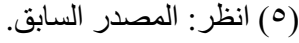

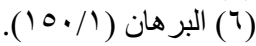

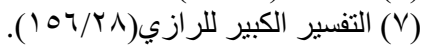

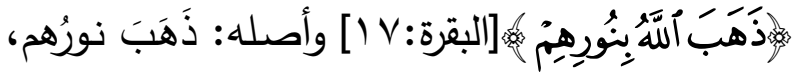
فإذا دخلت الهمزة أصبح التقدير : (أذهب الله نورهم). *من الأدلة على إفادة الباء للتعدية:

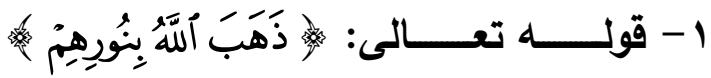

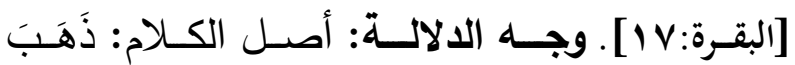
نورُهم، فلما دخلت الهمزة أصبح التقدير : (أذهب الله

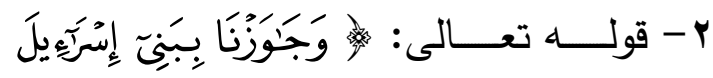

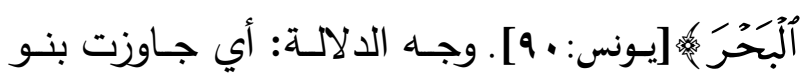

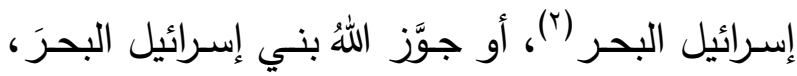
كما في قراءة: " وجَوَّزّنا"("). فوائد تنبيهات: 1- تسمى باء التعدية: باء النقل-أيضاً -. ب-مــن الفـروق بـين الفعـل المتعـدي وغيـر

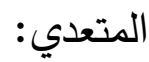
أولاً: الفعـل المتعـدي هـو الفعـل الـذي تجـاوز الفاعلَ إلى محلٍ غيره، وذلك المحل هو المفعول بـه، مثل الفعـل: (ضَـرَب)، وَ(قَتَل)، فـيمكن أنْ تقـول:

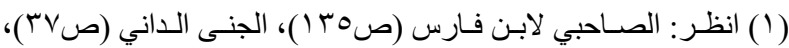

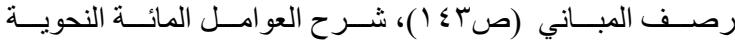

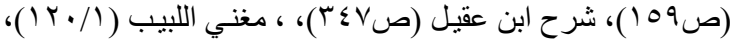

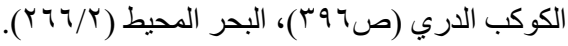

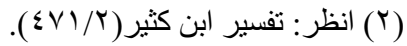

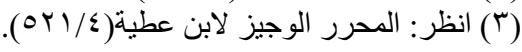


مستصــبين الكفـر فـي قلـوبهم(؛)، ومنــهـ قـولهم: اشترى الفرسَ بسَرْجِه، أي: مع سرجه، وقولهم: جاء زيدّ بسلاحه، أي ومعه سلاحهـ(0).

مــن الأدلــة علــى كــون البــاء تــأتي

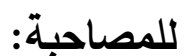

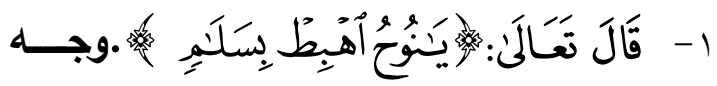

الدلالة: أن "الباء" في قوله:"بسلام" للمصاحبة؛ لأنها

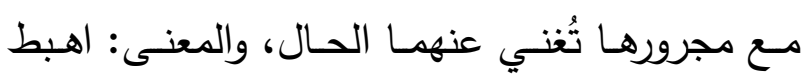

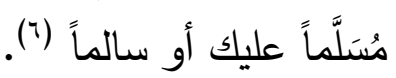

r- قَّالَ تَعَالَنا

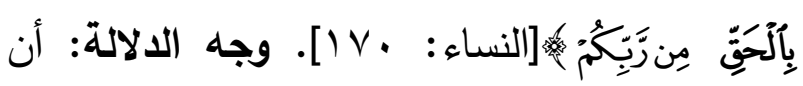

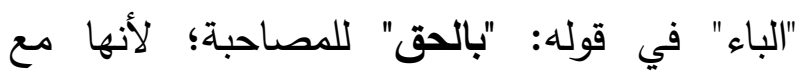
مجرورها تغني عنهما الحال، والمعنى: قد جاءكم الرسول مع الحق، أو مُحِقِّاً (V).

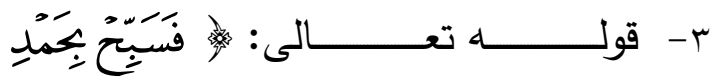

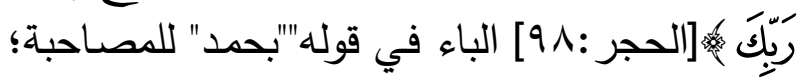

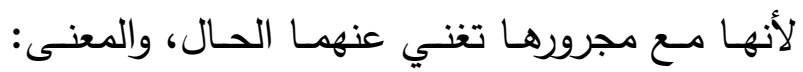

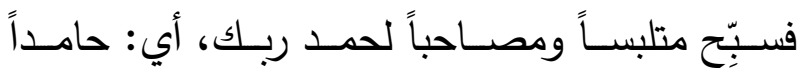
ربك (^).

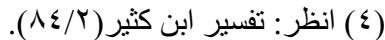

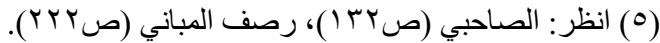

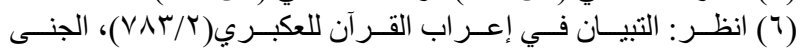

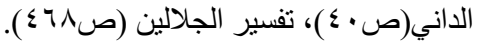

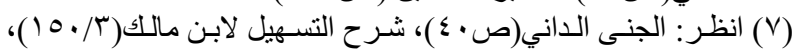

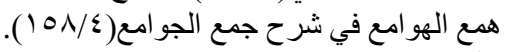

(^) (م) انظر: المصادر السابقة.
هنا للتعدية؛ لأن الفعل(أسفر ) يجيء مُتَعديًاً إلى لَى

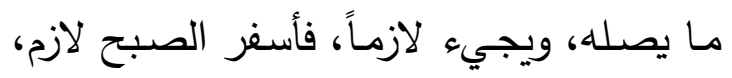

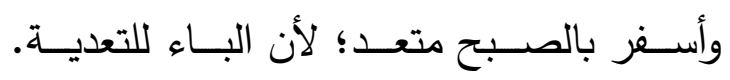

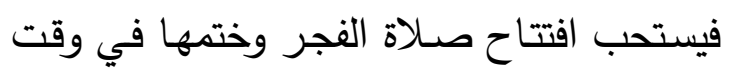
الإسفار ، وهو قول ظاهر الرواية(') r-بستحب عند المالكية الإبراد بصلاة الظهر

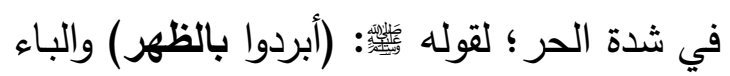

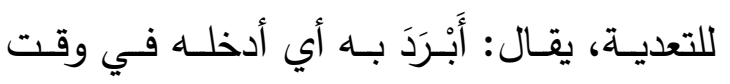

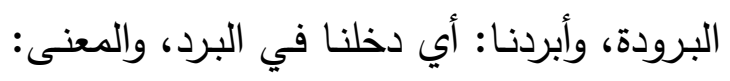
ادخلوا صلاةً الظهر في البرد، وهو سكون شدة البرد، والعنا:

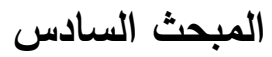

دلالة الباء على المصاحبة وتطبيقاتها الفقهية

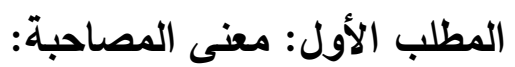

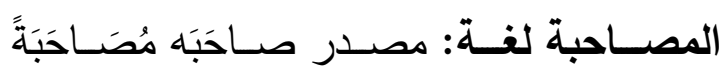
وصِـحَاباً أي: رافقـه وقارنـهـ وقاربه، والصـاد والحساء والباء أصل واحد يدل على مقارنة شيء ومقاربته (r). وبـاء المصـاحبة اصطلاحاً: هي التي يحسن مجيء (مع) في موضع "الباء" كقوله تعالى: وَوَقَّ

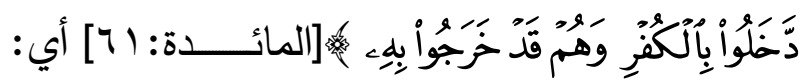

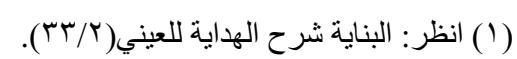

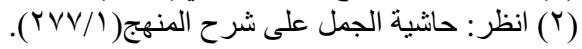

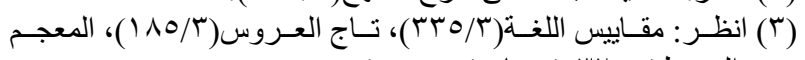

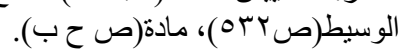


أنْ يكـون الملصَّق جـزءاً مـن الملصَّق بـه لا ينفكك فوائد وتنبيهات:

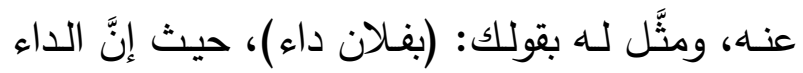

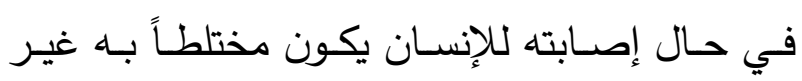

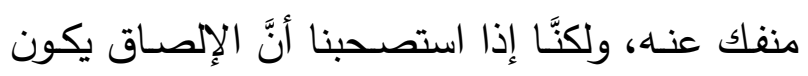
حقيقة ومجازا، زال هذا الإشكال.

المطلب الثاني: تطبيقـات فقهيـة لدلالـة البـاء

على المصاحبة:

المسـألة الأولى : أنَّ النية جزء من العبادة عند

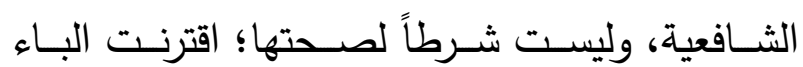

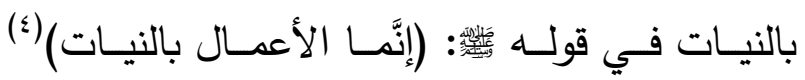
ويظهر أثر ذلك في أن النية شرط أو ركن، فذهب

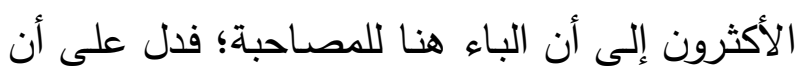

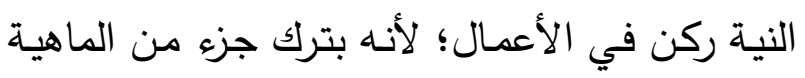

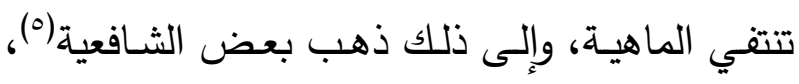

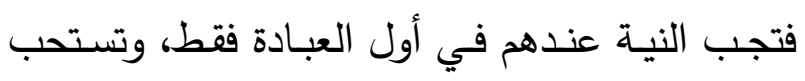

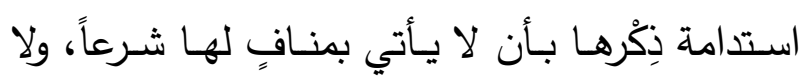

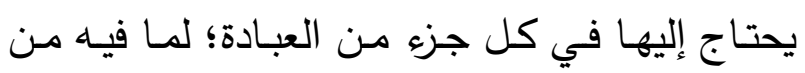
الحرج والمشقة(؟).

المسـألة الثانيـة: حكم من قـال لزوجتهـ: أنتـ

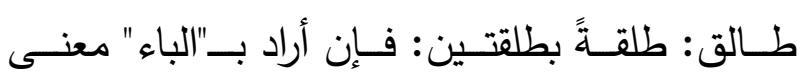

(ع) رواه البخاري في صحيحه( (T/7) بـاب بدءء الوحي، برقم(1) )، ورواه

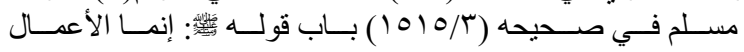

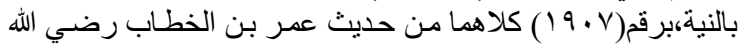
عنه.

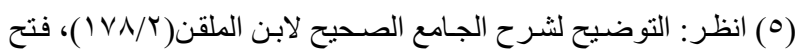

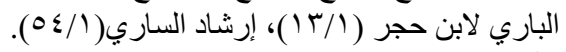

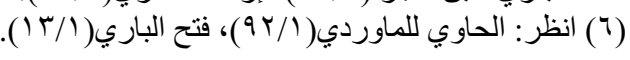

1 - لباء المصاحبة علامتان:

الأولـى : أنْ يحسـن أن يوضـع فـي موضـعها

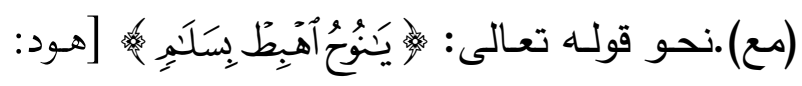
ع [ المعنى: اهبط مع سلام.

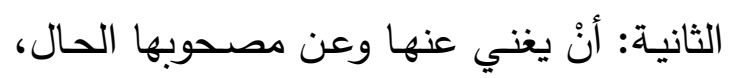

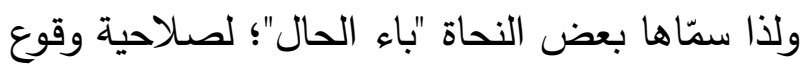

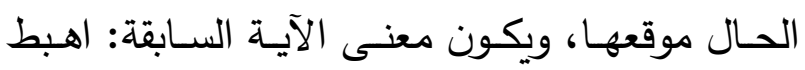

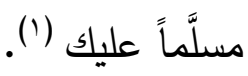

\section{ץ- هل المصاحبة من معاني الإلصاق؟}

قـال الثـيخ خالـا الأزهـري(r)-مجيــاً عـن هذا التساؤل -( الإلصـاق يستلزم المصـاحبة، والمصـاحبة

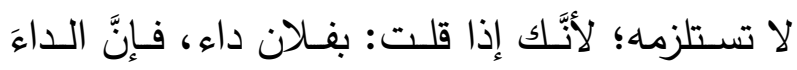
صاحِبّ له من حيث صار جزءاً منه، ولا ينفك عنها،

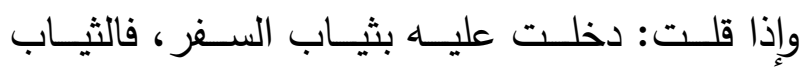

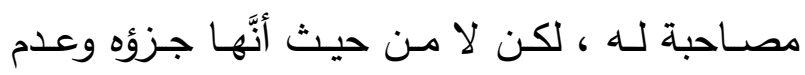

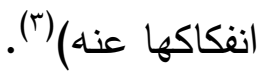

فيُفهرم مـن كلامــهـ أنَّ كـل إلصـاقٍ مصـاحبة،

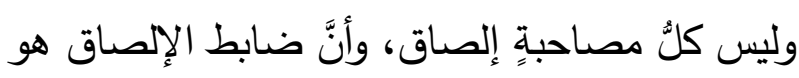

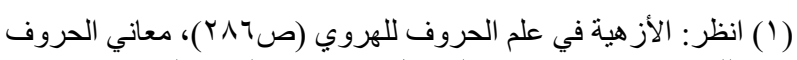

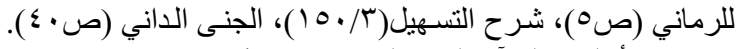

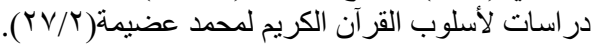

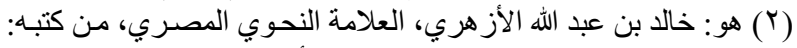

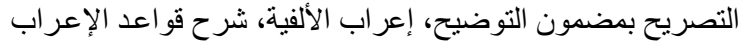

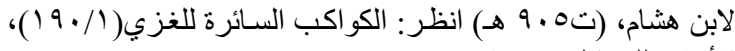

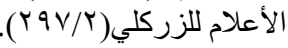

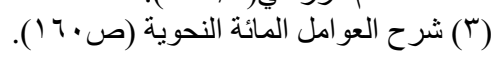


والزجاجي(؟)، وأبي علي الفارسي (v) من أئمسة اللغة،

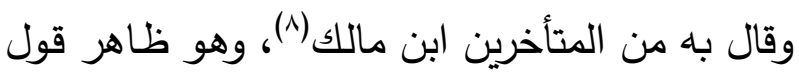
الإمام الثافعي (9). واستدلوا على أن الباء تفيد التبعيض بأدلة:

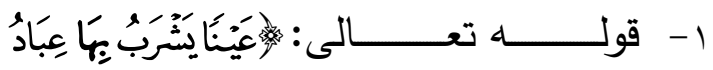

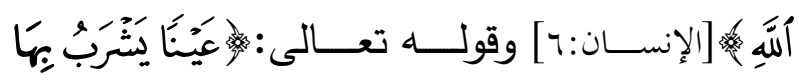

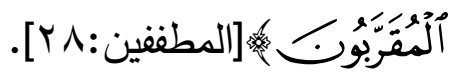

وجه الاستدلال: أن الباء في الآيتين في قوله:

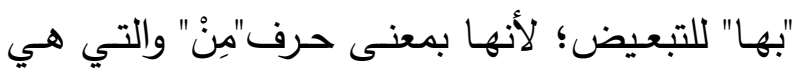
للتبعيض(·') (1)

ץ- عن المغيرة بـن شـعبة رضـي الله عنـه: (أنَّ رسول الله

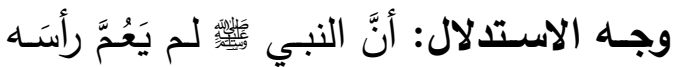

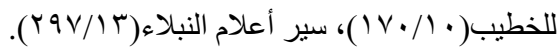

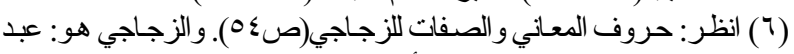

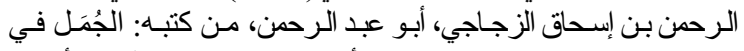

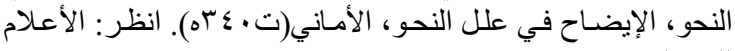

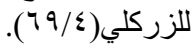

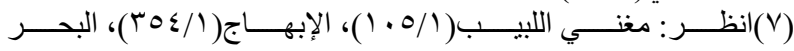

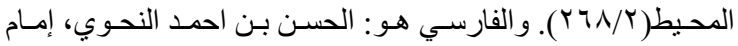

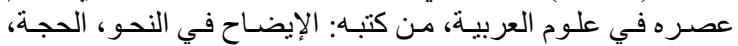

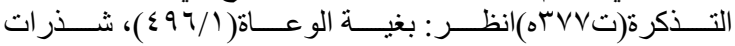

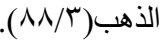

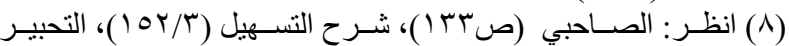

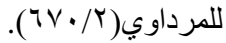

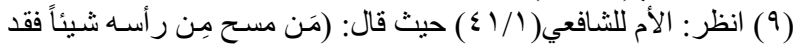

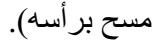

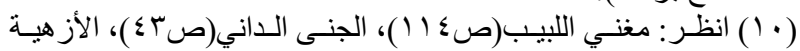

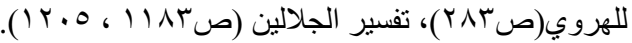

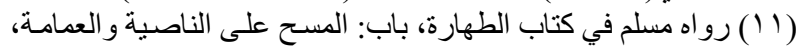

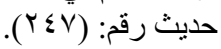

المصـاحبة-أي مـع طلقتين - طَلْقَتْ ثلاثاً، وإن أراد معنى"في" -أي في طلقتين-؛ طلُقت ثلاثاً، وإن أراد:

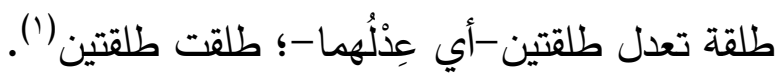

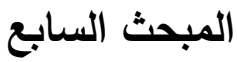

\section{دلالة الباء على التبعيض وتطبيقاتها الفقهية}

المطلب الأول: معنس التبعيض والخـلاف في

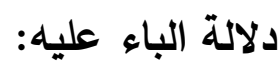

البـاء والعين والضـاد أصلـ واحد، وهو تجزئَة

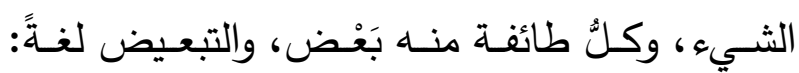

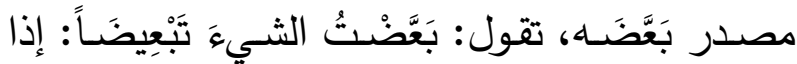
فَرََقْتُهُ إلى أجزاء (r). وعلامـة بـاء التبعيض أن يصـلح وضـع كلمـة (بعض) مكانها (r)

وقد اختلف العلمـاء في إفـادة الباء التبعيض على ستة أقوال أهمها قولان:

القـول الأول: أنَّ البـاء تفيـــ التبعيض، وإليـهـ ذهب الكوفيون، وهو قول الأصمعي(؛)، والقتيبي(؛)؛

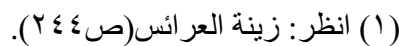

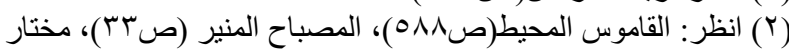

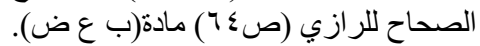

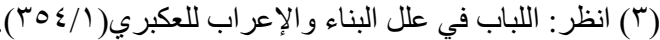

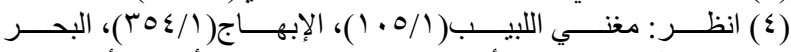

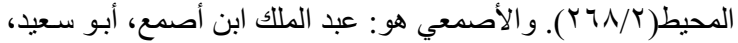

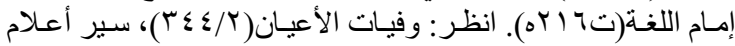

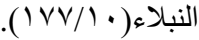

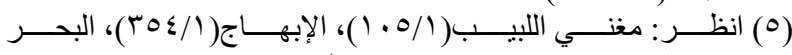

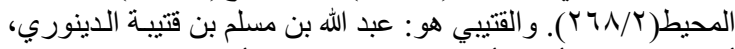

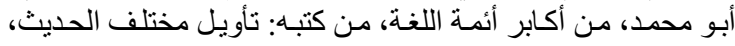

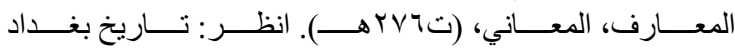


للتبعـيض يؤولـون تلـك المعـاني، أو يضــــنون الفعل الذي دخلت عليه الباء معنى فعلٍ آخر

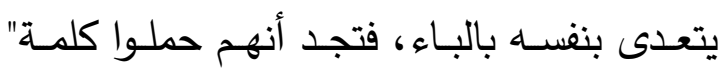
شَرِبْنَ " في البيت السـابق على كلمـة" رَويـنَ " التي تتعدى بالباء (v).

ه- أن دخول الباء في الفعل الذي يتعدى بدونها لغير فائدة لغو؛ فوجب حملها على التبعيض. צ- أن أهل اللسان يفرِّون بين قولهم: "أخذتُ

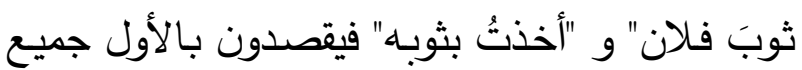

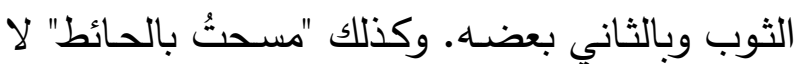

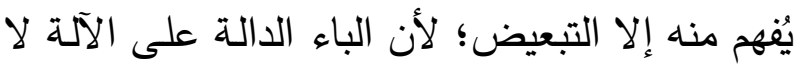

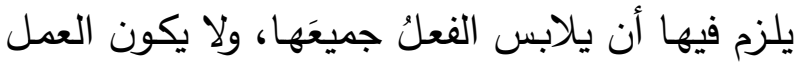

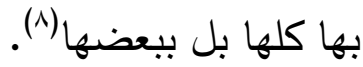

ونوقش بأن التبعيض هنا بالقرينة لا بالوضـع،

$$
\text { والقرينة ليست حجة(9) . }
$$

القــول الثـاني: أنَّ البــاء لا تفيـــ التبعـيض

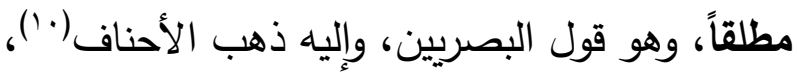

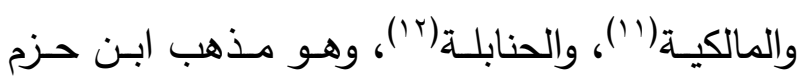

التضمين للشيخ حسين والي في مجمع اللغة العربية ب ب إه اه.

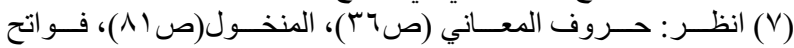

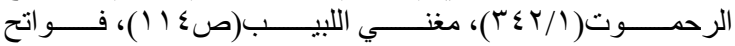

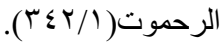

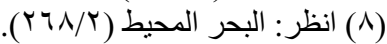

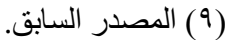

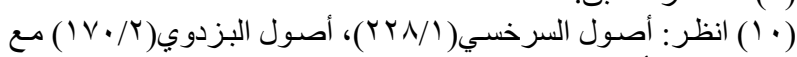
كثف الأسرار.

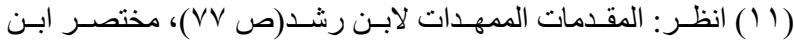

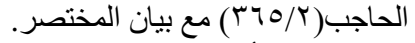

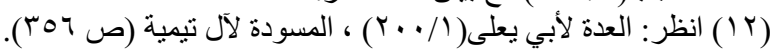

بالمسح، كما هو واضح'(')

ب- قـال أبـو ذؤيسب الهـذلي (ץ) يصـف الغَنَام

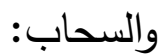

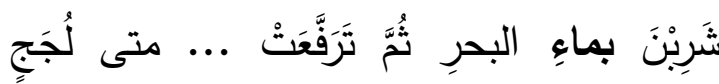

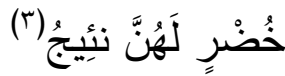

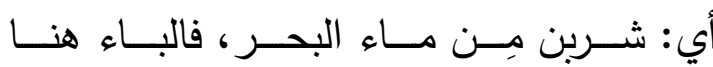

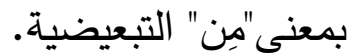
ع- ق قال الثاعر : فَلَثْنَتُ فاها آخِذَاً بِقُرُونِها...شُرْبَ النَّزَيفِ بِتَرْد ماءِ الحَشْرَج

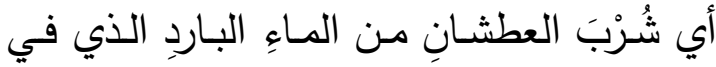

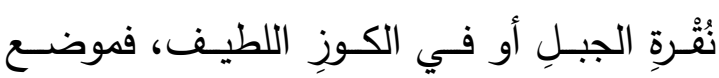
الثاهد قوله:" بِبَرْد"؛ فإن الباء فيه بمعنى : "مِن" فتقيد التبعيض(0). واعتــرض علــى هــــه الثـــواهد بالتأويـلـل أو

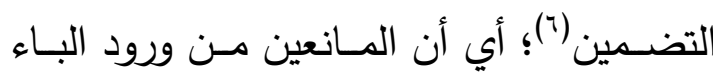

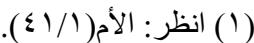

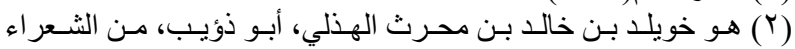

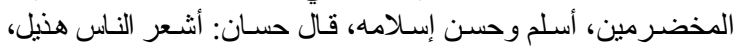

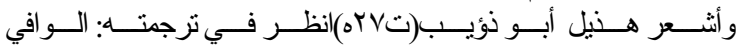

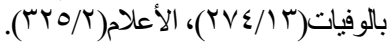

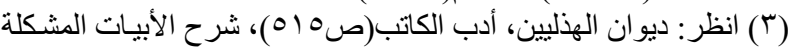

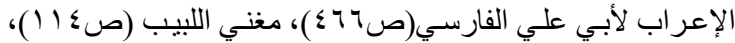

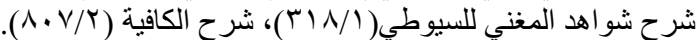

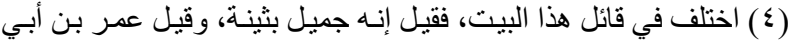

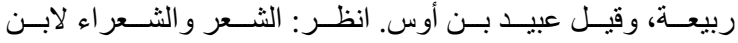

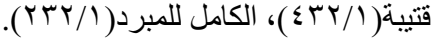

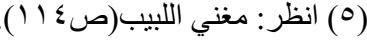

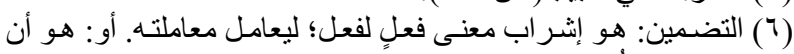

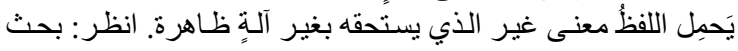


يعرفـه أصــحابنا، ولا ورد بــهـ ثَبْهـ)(9)، وقــال ابـن برهان:(من قال إن الباء تأتي للتبعيض؛ فقد أتى أهل

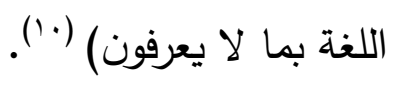

\section{واعترض عليه باعتراضين:}

أولهمــا: أن الشـهادة على النفي غيـر مقبولـة، فلنـا أن نُخطّى ابـن جنـي بالـدليل الظـاهر الـذي

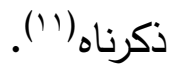

وأجيب بأن هذا ليس شهادة على نفي؛ إنما هو

إخبار مبني على ظن غالب مستتد إلى الاستقراء (ri) ممن هو أهل لذلك مطّلع على لسان العرب، كما في سائر الاستقراءات، لا يقال فيها: شهادة نفي، وحينئ فتتوقف مقابلته على ثبوت ذلك من كلامهم (rا'). ورُدَّ بأن جمعاً من أئمة اللغة كالأصمعي والفارسي وابن مالك أثبتوا أن الباء تأتي للتبعيض (ء ') ونوقش بأن الأئمة المثبتين للتبعيض فرّقوا بين

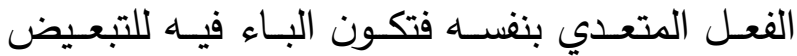
-حذراً من زيادتها- وبين غير المتعدي فـلا يكون

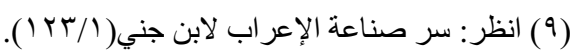

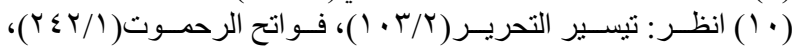

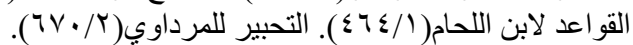

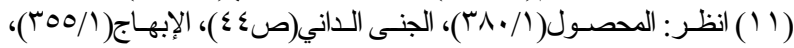

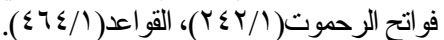

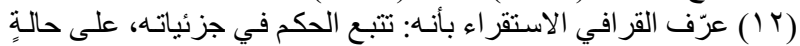

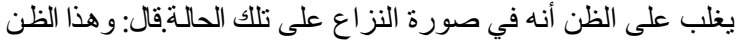

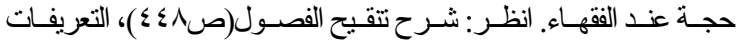

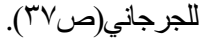

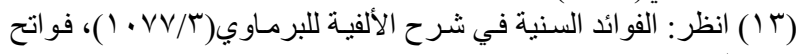

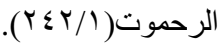

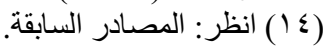

الظـاهري (')، واختـاره الزمخشـري(؟)،وابـن بَرْهـان (r)،

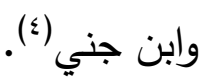

\section{واستدلوا على أن الباء لا تفيد التبعيض بأدلة:}

ا - أنَّ حـذّاق أهــل العربيــة أنكــروا ورود البــاء للتبعيض.

قال أبو بكر عبد العزيز (*):" سألت ابن دريد(آ)

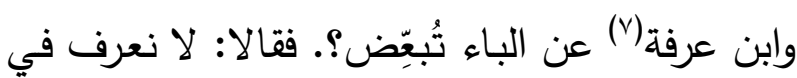
اللغة الباء تُبعَّض (^).

وقـال ابـن جنّي: (فأمـا مـا يحكيـهـ أصـحاب الثـافعي رحمـه الله من أنَّ الباء للتبعيض، فشيء لا لاءل

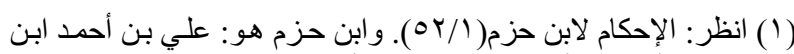

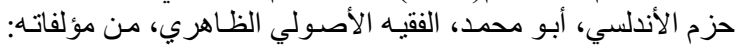

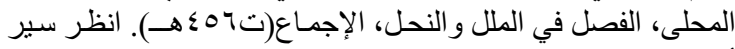

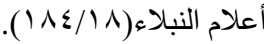

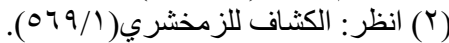

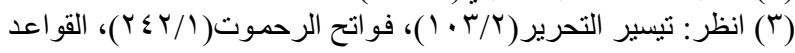

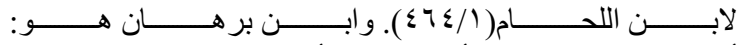

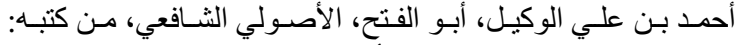

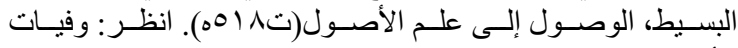

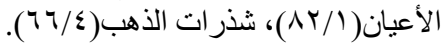

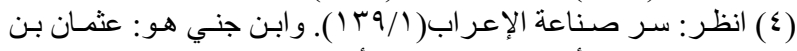

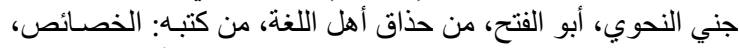

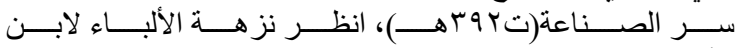

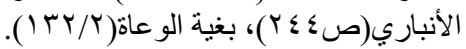

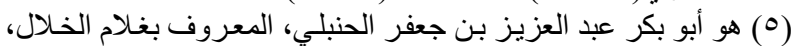

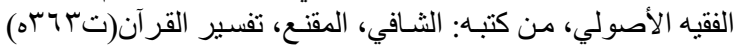

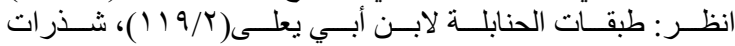

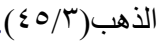

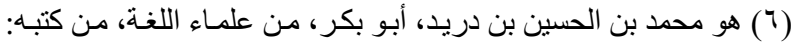

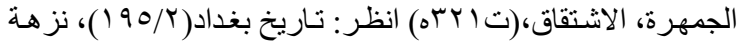

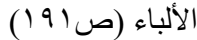

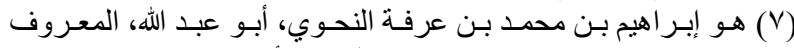

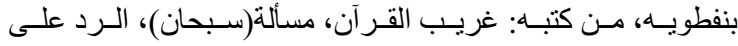

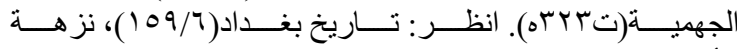
الألباء(صع 9 1) ).

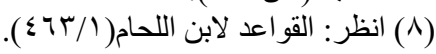


الفعل بالمفعول بـه؛ فدل على أن مقتضـى

كذلك (').

اللفظ ليس إلا إلصاق الفعل بالمفعول به(؟).

ونــوقش بـأن قـولهم: "مـررتُّ بزيـدي" و "كتبــتُ

واعتُرض بـأن كونهـا زائدة لا ينـافي أن تكون

بالقلم" إنما أفاد ذلك لأنه لا يتعدى بنفسـ؛ فلا يجوز أن يقال: "مررتُ زيداً" و "كتبتُ بالقلم" فلذلك أفاد ما لاد

وأما الطواف فهو عبارة عن الدوران حول جميع البيــ؛ ولهـذا لا يسـمى مـن دائرر ببعضـهـ طائفـاً

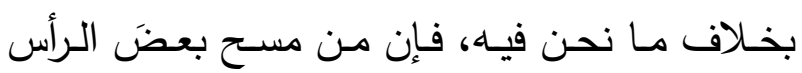

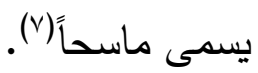

ج- أن البـاء تدخل على مـا لا يقبـل التبعيض؛

كقولهم: "استعنتُ بالله"(^).

هـذان القـولان هـــا أهـــ الأقـوال فـي المسـألة، وهنالك أقوال أخرى أذكرها إتماماً للبحث:

القـــول الثالـــث: يشــرط لدلالـــة البــاء علـى

التبعيض ورودها على فعلٍ يتعدى بنفسـه، فقالوا: إذا كان الفعل يتعدّى من غير الباء؛ فـلا يحتاج إليها للإلصـاق؛ فوجـب حملـه على التبعيض؛ لأن حمـل كل حرفٍ من القرآن على ما يفيد أولى، وهو قول

ويمكـن أن يجـاب بأنـهـ لا يوجـــ مـا يمنـع مـن اشتراك حرفين في الدلالة على نفس المعنى، كما تدل"ثم" و "الفاء" على الترتيب.

ب-أن البـاء لا تفيـد التبعيض لامتتـاع دخولهـا

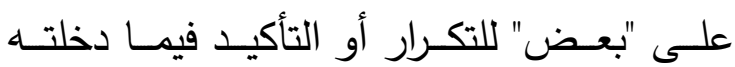
بـ"كل" للتتـاقض، فكمـا يمتتـع أن يقـال "مسـحتُ

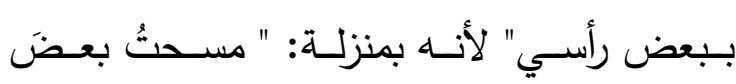

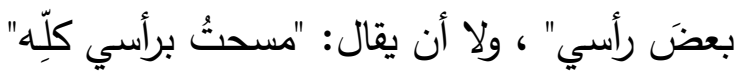

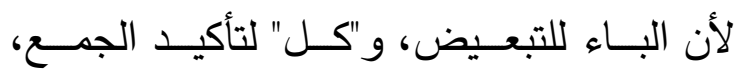
وجمعهما على شيء واحد تتاقض (ء). ع - أن الاستثناء يدخل على معمول "الباء" كأن يقـال: "امسـح برأسـك إلا ثلثـه" والاسـتثناء

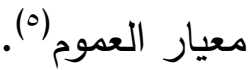
ه- أن القائـل إذا قـال: "مـررتُ بزيـدِ" و "كتبــُ بـالقلم" و "طفـتُ بالبيـت" عَقَّلوا منـهـ إلصـاق 
فالتبعيض يستفاد من مصدر المسـح؛ لأنَّ المسـح لا يـدل على الاسـتيعاب، وكـذلك مصــدر الضـرب،

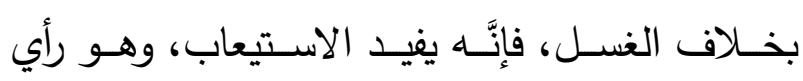

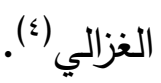

القول الخامس: إنْ دخلت الباء على آلة المسح، نحو:"مسحتُ بالحائطِ وبالمنديل" فهي للكل؛ لأنه أضيف إلى جملة، وإنْ دخلت على محل

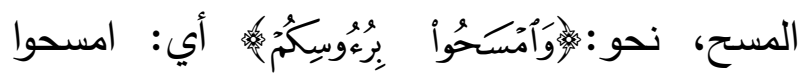
أيديكم برؤوسكم؛ لا تتناول الكل، وهو رأي بعض الحنفية (0).

ووجه هذا القول: أن الآلة غير دقصودة، بل هي واسطة بين الفاعل والمفعول في وصول أثره إليه، والمحل هو المقصود في الفعل المتعدي فلا يجب استيعاب الآلة بل يكفي فيها ما يحصل به

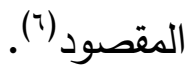

القـول الســادس: أنهـا تقتضـي الشــول، وهـو مذهب بعض الحنابلة(`)، ورجحه القرافي(^). واستدل على ذلك بدليلين: الاليل الأول: أنَّ لفظ (مَسَحَ) يتعدى لمفعولين:

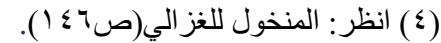

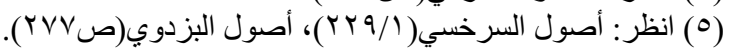

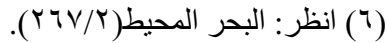

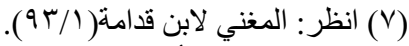

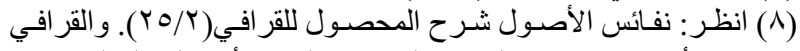

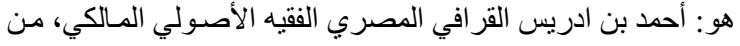

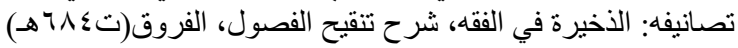

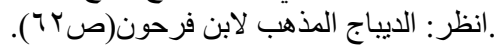

$$
\text { واستدل على ذلك بلاليلين: }
$$

الاليل الأول: أنَّ زيادة البايَ في الكلام لا تخلوا

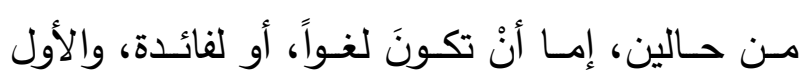
باطل؛ لأنَّ حمل الكلام على اللغو خلاف الأصل، إنل فيثبـت بـلك أنَّهـ يفيد فائدة زائدة، وهذه الفائدة هـي

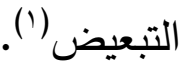
الـدليل الثـاني: أنَّا نفرق بالضـرورة بين قولنـا: "مسحتُ يدي بالمنديلِ والحائط"، وبين قولنا:"مسحتُ المنـديلَ والحــائط" فـي أن الأول للتبعـيض والثـاني للشمول، فيكفي في صحة صدق الأول أنْ يمسح يده بجزء من أجزاء المنديل (؟). وأجيـب بأن ذلك أمـر آخر يرجه إلى الإفـراد والتركيـب، وهـو أن "مسـحتُ يـدي بالمنـديل" سـيق التيل لإفادة ممسوحٍ وممسوحٍ به، والباء إنما جيء بها لتفيد

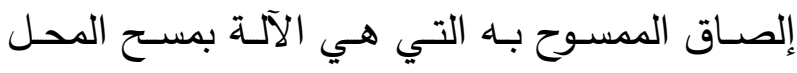
الذي هو اليد. وقولـه: "مســـُ المنـديلَ والحـائط" إنمـا سـيق

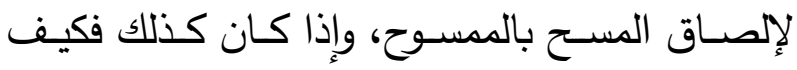

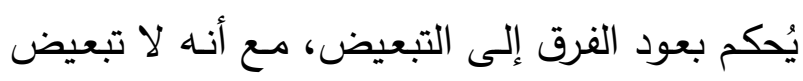

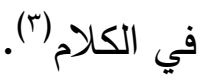

القول الرابـع: أنَّ الباء لا تفيد التبعيض، وإنَّمـا يُسـتفاد التبعـيض مـن مصـدر الفعـل لا مـن البـاء،

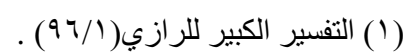

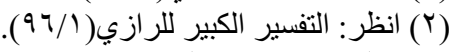

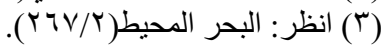


إنَّما هو فرض الرأس وليس اليد، فكيف يستقيه؟.

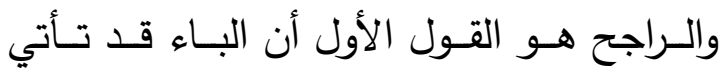

للتبعيض كما هو ظاهر في الشواهد السابقة . تنبيهه : شََّّك الإمامان الزركثي والإسنوي في نسبة القول بأن الباء تأتي للتبعيض للإمام الثافعي لتحي

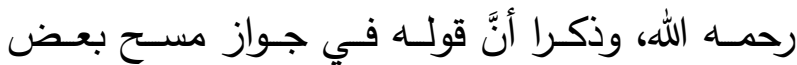

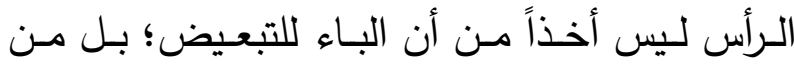

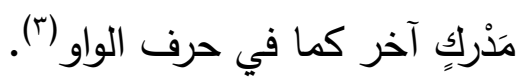

ولكـن هــا التشـكيك لا يسـاعده ظـاهر كـلام الإمام في الأم، فقد قال في قولهه تعالى: هولَأمُسَحُواُ

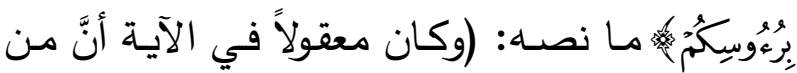

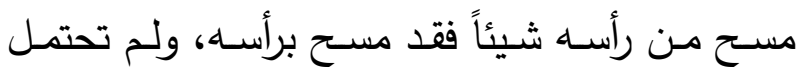
الآيـة إلا هذا، وهو أظهر معانيها، أو مستح الرأس كلهـ. ودلت السنة على أنـه ليس على المره مسـح الرأس كله، وإذا دلت السنة على ذلك؛ فمعنى الآية أن من مسح شيئًا من رأسه أجزاه)(؛).

فظـاهرٌ مـن كلامـهـ هـذا أنَّ الآيـة تـدل على معنيـين، الأول: هـو مسـح بعض الـرأس، والثاني:

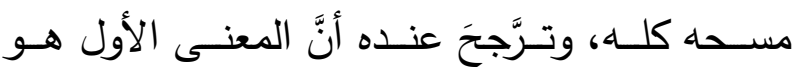

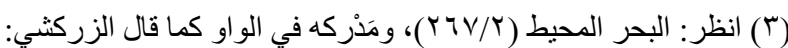

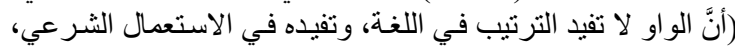

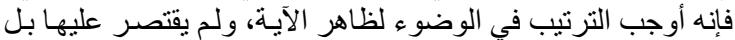

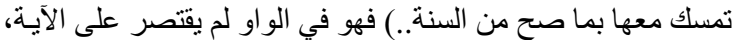

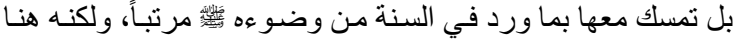

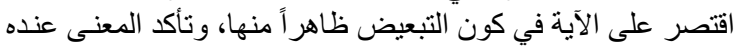
بالسنة كما هو واضح في لفظه، والإن الله أعلم.

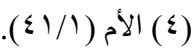

أحدهما يتعدى لـه بنفسـه، والآخر يتعدى لـه بحرف جر وهو الباء، فالفعل(مَسَح) سيق ليتعدى لهفعولين

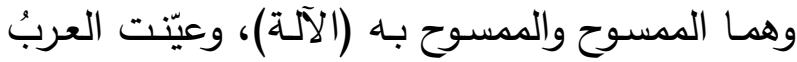
الباء للمفعول الذي هو الممسوح به الذي هو الآلة. وتوضيحه أنَّه إذا كانت الرطوبة في يدك قلت:

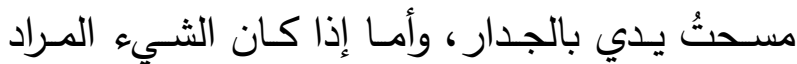
إزالته على الجدار قلت: مسحتُ الجدارَ بيدي، ولا يجيز العرب غير هذا'('). الدليل الثاني: أنَّ الأمسة مجمعة على أنَّ الله لم

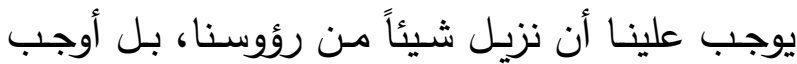
علينا نقل الماء لرؤوسنا، فحينئذ الرأس هي المزيلة، واليد هي المزال عنه، وحينئذ يكون التقدير : (امسحوا

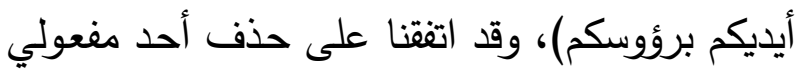

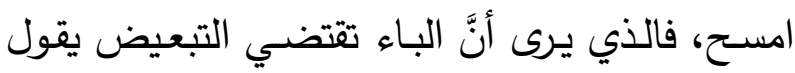

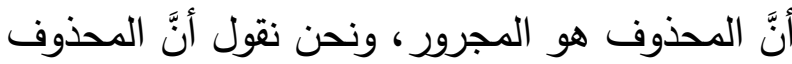

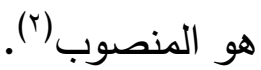

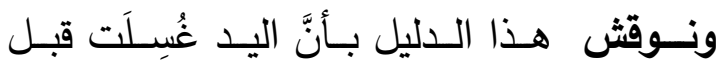

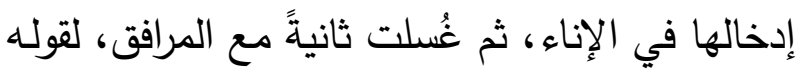

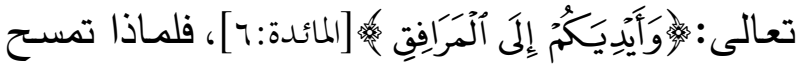
ثالثاً بالرأس؟ ثمَّ إنَّ اليد هي التي يُغسل بها الوجها وتُمستح بها الأذن، فيكف تُمسح هي بالرأس لتطهر ؟ والمسح

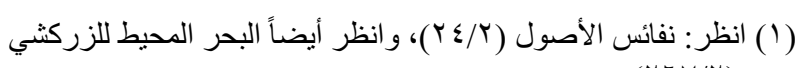
( (YTV/r) (Y) (Y) انظر : نفائس الأصول(Y (Y (Y). 
وهومذهب الأحناف(")، ورواية عن الإمام أحمد(؛). وقال ابن العربي(0): إن الباء في هذه الآية تفيد فائدة غير التبعيض؛ وهي الدلالة على ممسوح به.

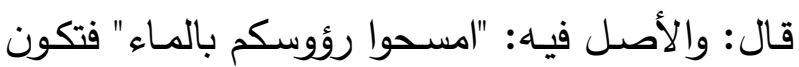
من باب القلب، والعرب تستعمله، والأصل: "امسحوا رؤوسكم بالماء" (ج).

وهذا مـن ابن العربي إخراجٌ للبـاء مـن كونها

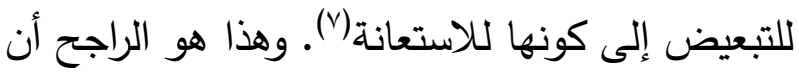

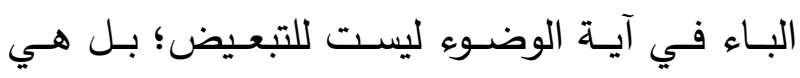
للدلالة على ممسوح به كما قال ابن العربي.

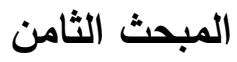

\section{دلالة الباء على العِوَض وتطبيقاتها الفقهية}

المطلب الأول: معنى العِوَض وأقسامه:

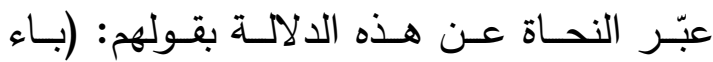
العِوَض)، وقال آخرون: (باء التعويض) (^). * ومعنى بـاء العِوَض: هي الداخلة على الأثمان

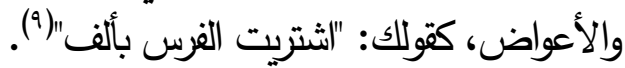

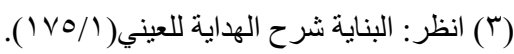

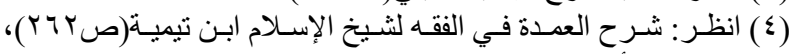

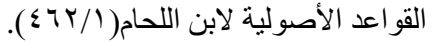

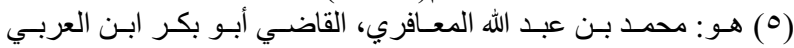

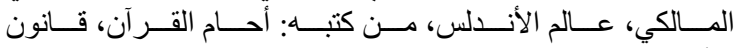

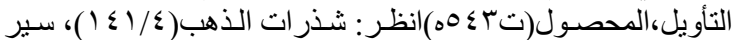

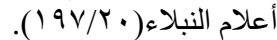

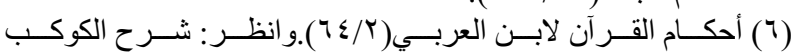

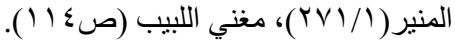

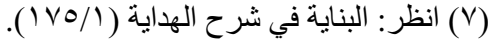

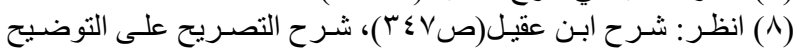

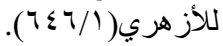

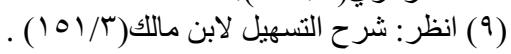

الأظهر، واستدلاله بهذا كان عن طريق الآية وحدها دون الاستـلال بالسنة، ولكن لما دلت السنة أيضـاً على جواز مسـح بعض الرأس تأكَّد المعنى الأول عنده، ولذا قال: (وإذا دلت السنة على ذلك فمعنى

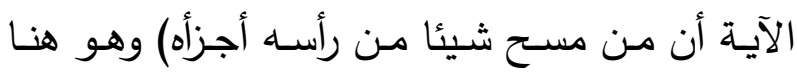

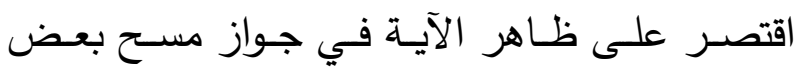
الرأس، ومحتملُ منها مستح جميع الرأس، ثم ترجح

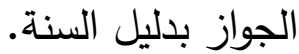

ويؤكد صحة القول بأن الإمام الشافعي يرى أن

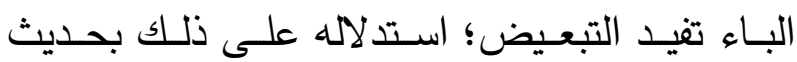

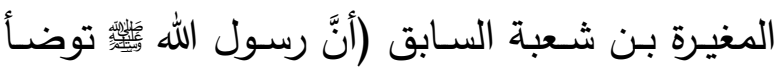

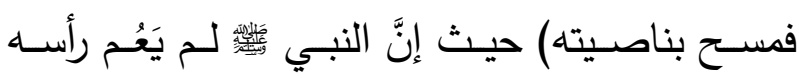
بالمسح (')

والأظهـر أنَّ البـاء عنــــ الإمـام الثـافعي تفيـد التبعيض من غير تفصيل، وعند كثير من أصحابه

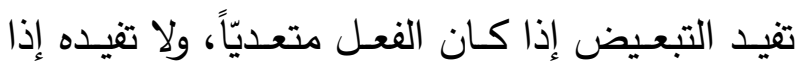

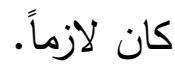

المطلب الثاني: تطبيقات فقهيـة لالالـة البـاء

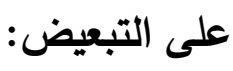

$$
\text { "استدل الإمام الثافعي بقوله تعالى: }
$$

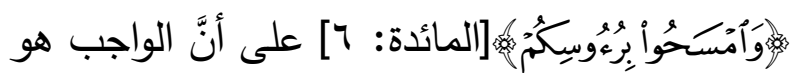
مسح بعض الرأس في الوضوء، وهو مبني على أنَّ

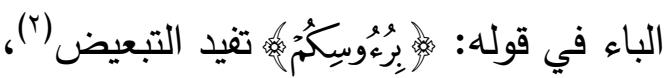

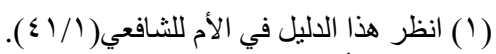

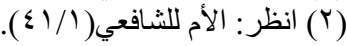


ب-قال الزركشي في معرض ذكره لغلط يقع فيه المصنِّفون في الباء: "حين يُدخلونها مع فعل الأبدال على المتـروك، فيقولـون: لـو أبـلـلت ضـاداً بطـاء.

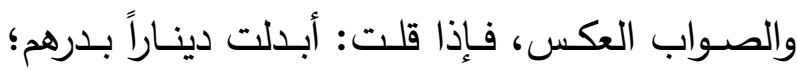

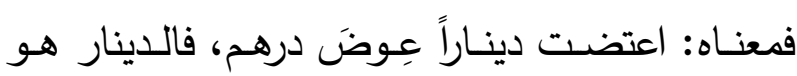
الحاصل لك المعوّضض، والدرهم هو الخـارج عندلك

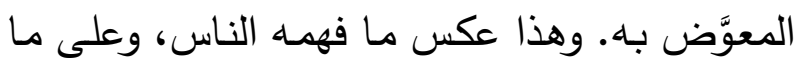
ذكرنا جاء كلام العرب"(0). * من الأدلة على إفادة الباء العوض:

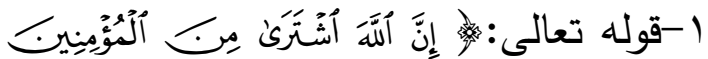

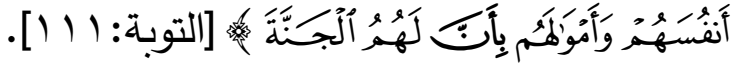
وجـهـ الدلالــة: أن البـاء هنـا للعِوض، قـال ابن العربي: " فإن الجنة لله، والعبادُ بأنفسهم وأموالهم الله،

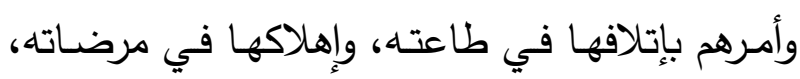

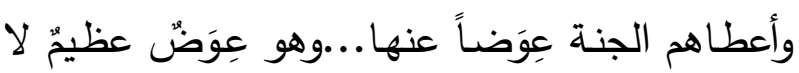

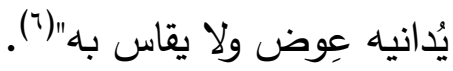

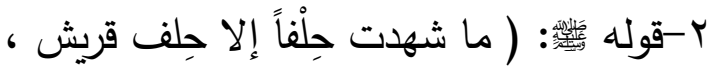

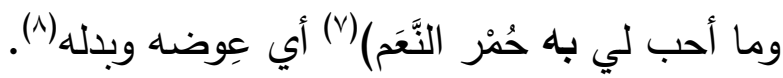
ب-قال علي بن أبي طالب رضـي الله عنه-

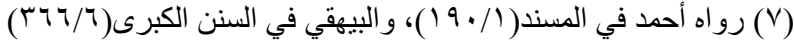

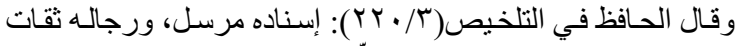

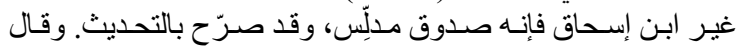

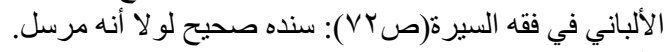

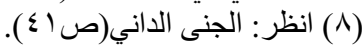

* هذا وقد قسّم الأصسوليون والنحساة العِوَض إلى قسمين: - إن 1- عِوض حسـي؛ كقولـك: "اشـتريت الكتاب

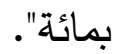

r- عِوَض معنـوي: كقولـك" "قابلـتُ إحسـانه

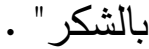

\section{فوائد وتنبيهات:}

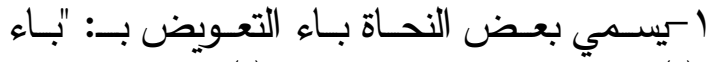

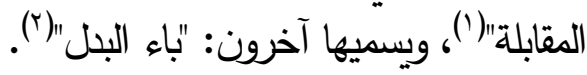

قال المـرادي: (ولم يذكر أكثرهم هذين المعنيين،

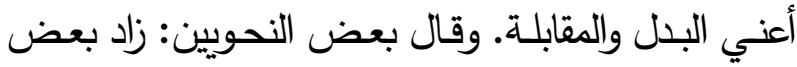

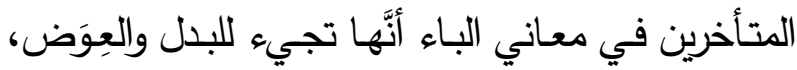

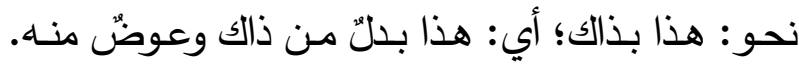
قال:والصحيح أنَّ معناها السبب؛ ألا ترى أن التقدير : هذا

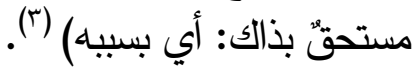

والذي دعى إلى القول بأن باء العوض تعود

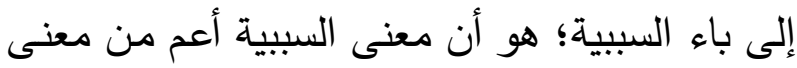

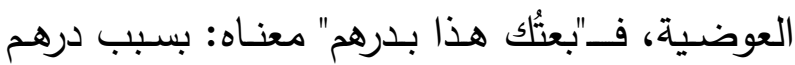

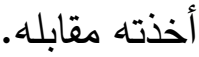

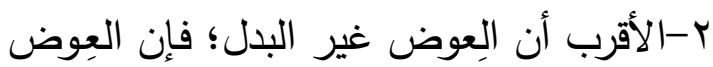

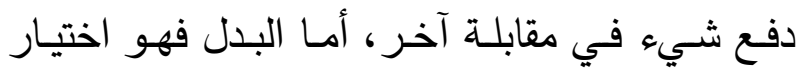

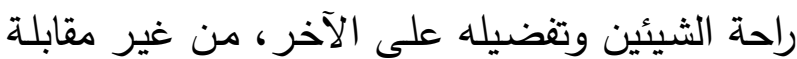

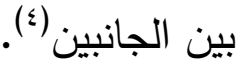

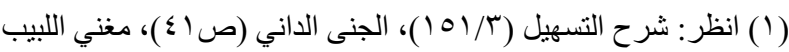
( $(1) / 1)$

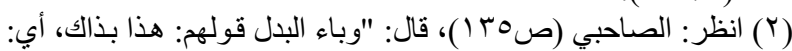
عوض منه".

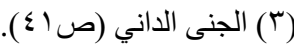

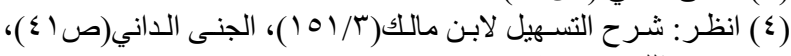

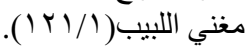


بكافر ) (V) على عدم قتل المسلم بالكافر ؛ وهو قول

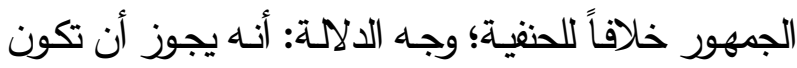
الباء في قوله: "بكافر" للعوض والمقابلة (^).

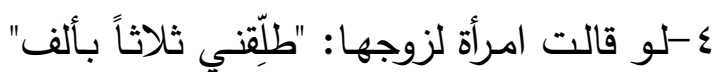

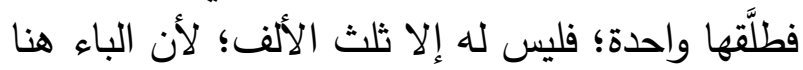

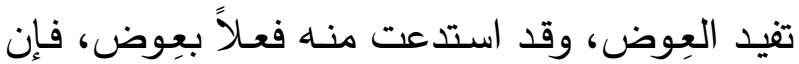
فعل بعضه استحق قِسطه من العِوض.

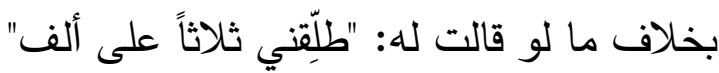

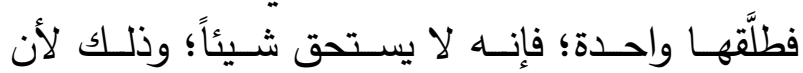

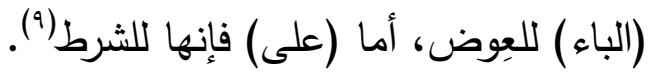
المبحث التاسع

\section{دلالة الباء على الظرفية وتطبيقاتها الفقهية}

\section{المطلب الأول: معنى الظرفية لغة وإططلاحاً:}

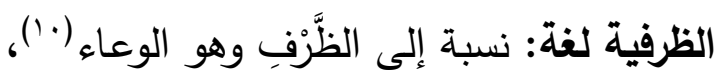

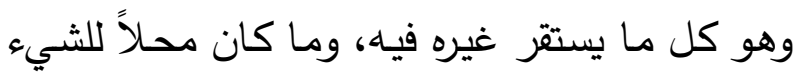

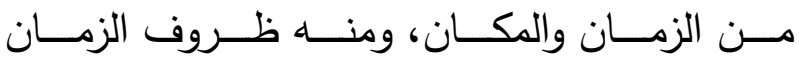
والمكان (1) (1)

\section{والظظرفيـة اصـطلاحاً: هـي وقتَّ أو مكانٌ ضُمِّنَ} معنى: "في" باطراد، كقولك: اجلسن ضحى الجمعة أملى أمام

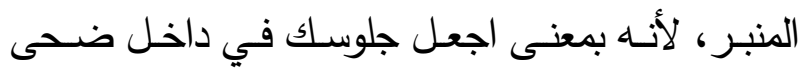

$$
\begin{aligned}
& \text { (V) رواه البخـاري في كتاب الديات، بـاب لا يقتل المسلم بالكافر ، رقم }
\end{aligned}
$$

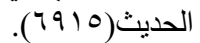

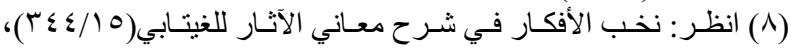

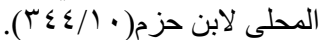

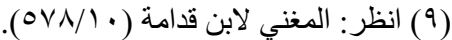

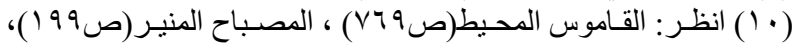

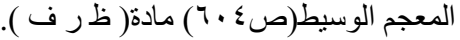

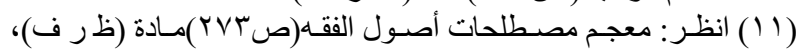

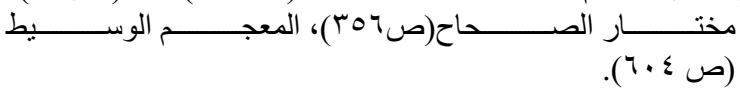

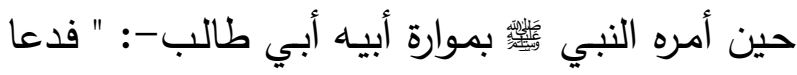
لي بدعوات ما يسرني أن لي بها حمر النعم"('). ع- قال الحماسي: فَليَّ لي بِهُمُ قوماً إذا رَكبوا

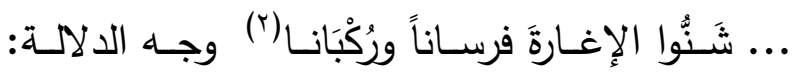
قوله:" بهم" أي بدلهم وعوضهم.

\section{المطلب الثثاني: تطبيقـات فقهيـة لالالـة}

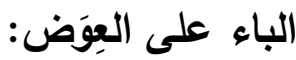

ا-استـل على جواز أنْ يكون المهر منفعة -

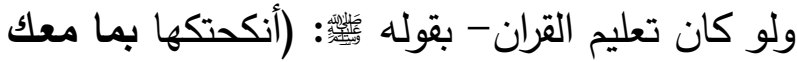

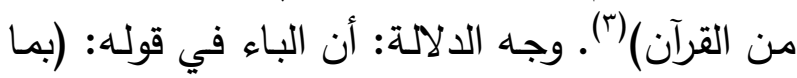

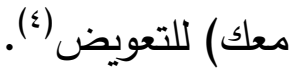

r-استذل الحنابلة بقول النبي (الظهر يركب بنفقته إذا كان مرهوناً، ولبن الدر يشرب بنفقته إذا لإل كان مرهوناً، وعلى الذي يركب ويشرب النفان النفقة) (०).

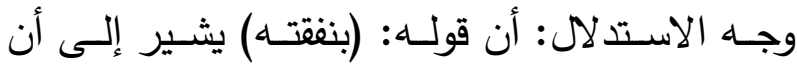

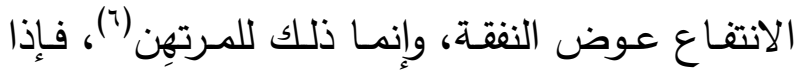

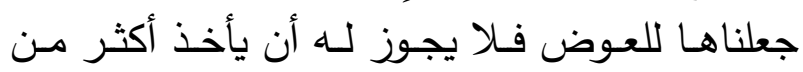
النفقة التي يدفع.

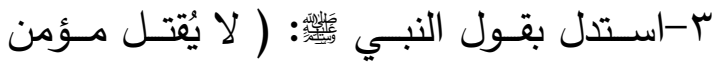

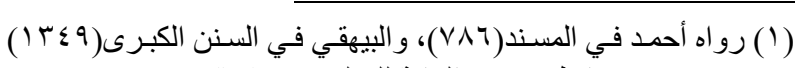

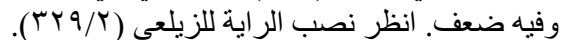

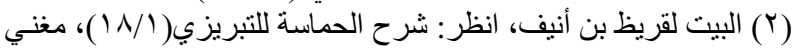

اللبيب( ع - (1)

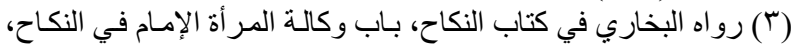

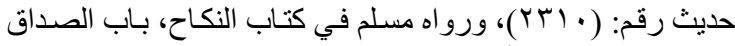

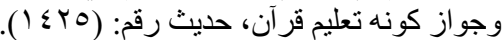

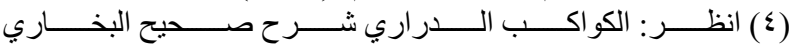

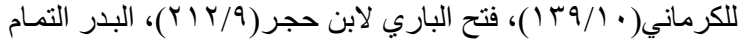

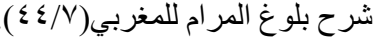
(0) رواه البخاري في كتاب الرهن، بـاب الرهن مركوب ومحلوب، رقم

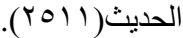
(7) انظر : المغني(1/7) (0). 
"وبالليل" ظرفيـة بمعنى "في"؛ لإن معنى الآيـة: وإنكم لتترون عليهم في الصباح وفي الليل (०).

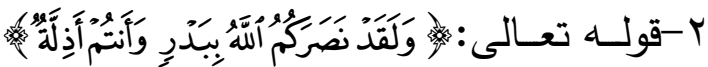

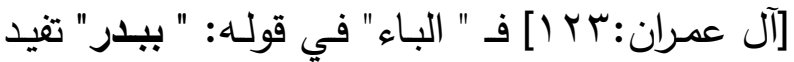
الظرفية؛ والمعنى: ولقد نصركم الله في بدر (").

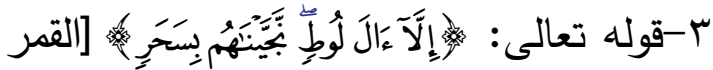

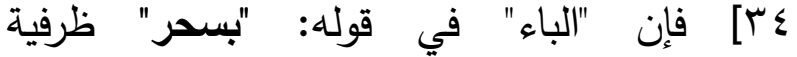
بمعنى"في"، والمعنى: نجيناهم في وقت السَحَر (لان.

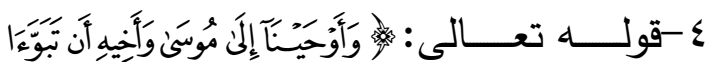

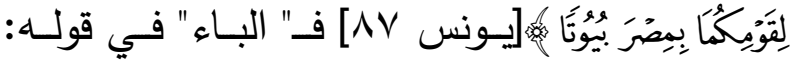
"بمصر" ظرفيـة بمعنى"في"، فالمغنى: اتخذا لقومكما

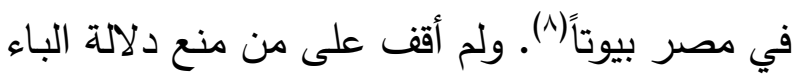
على الظرفية.

المطلب الثاني: تطبيقات فقهية لالالة الباء

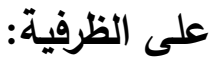
المسألة الأولى: مَنْ قال مشيراً لزوجتيه: طلّقتُ هذه بهذه: فإن أراد بها باء السبيية لم تطلق الثانية،

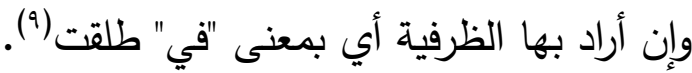

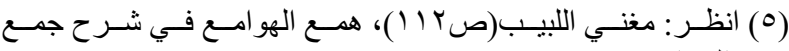

$$
\begin{aligned}
& \text { (T) انظر : المصدرين السابقين. }
\end{aligned}
$$

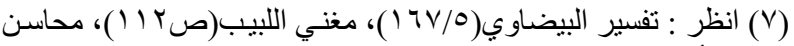

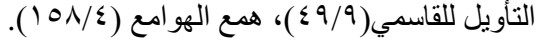

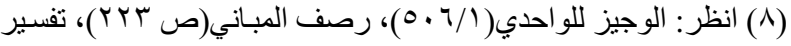

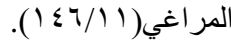

$$
\begin{aligned}
& \text { (9) انظر : زينة العرائس ( ص ع ع ب). }
\end{aligned}
$$

الجمعة، وفي داخل مكان أمام المنبر ('.

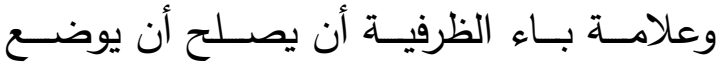
محلها: "في". والظرفيـة: حلول شيء في غيره حقيقةً نحو:

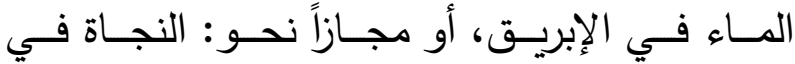

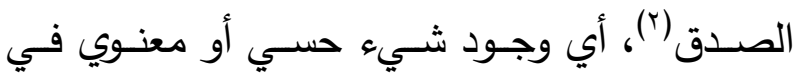
شيء حسي أو معنوي.

وتتقست الظرفيـة إلـى مكانيـة وزمانيـة، ومثال

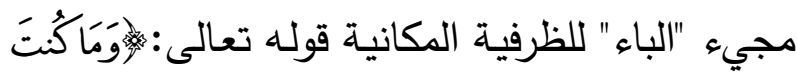

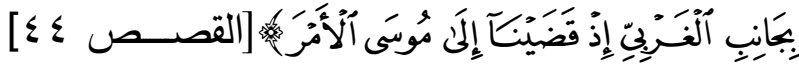

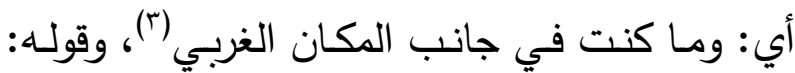

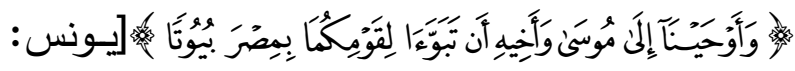

ومثال مجيء البـاء للظرفيـة الزمانيـة: قولـهـ

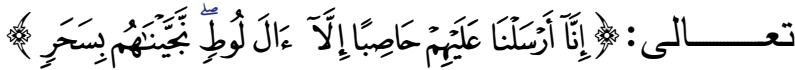

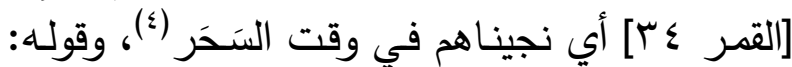

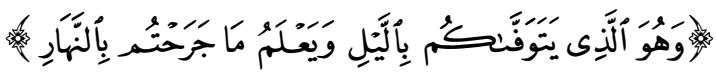

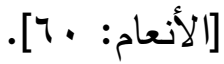

\section{"من الأدلة على إفادة الباء للظرفية:}

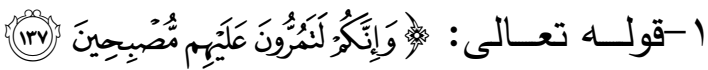

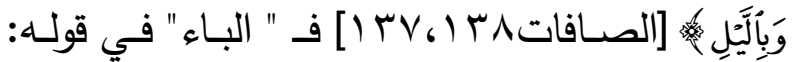

$$
\begin{aligned}
& \text { (1) وفي هذا يقول ابن مالك في الألفيةُ(ص • ب): الظرف وقتُ أو مكانُ }
\end{aligned}
$$

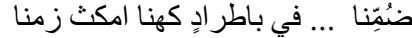

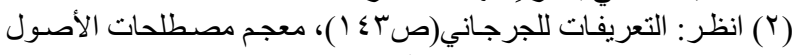

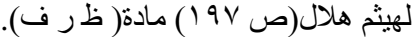

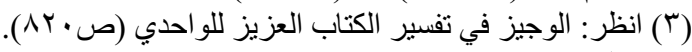

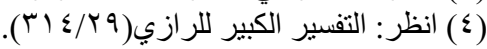


"أقسم بالله لأفعلن"، والمعنى: أن "الباء" تأتي للقسم

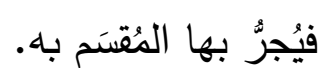

بخــلاف واو القســــ فإنهـــا لا يظهــر معهـــا

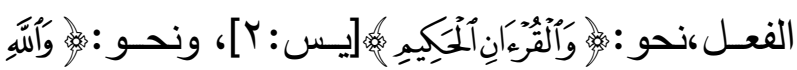

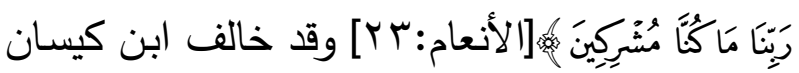
فقال بجواز إظهار الفعل مع الواو (0). و"والواو" أكثر استعمالاً من "الباء".

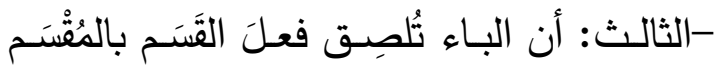

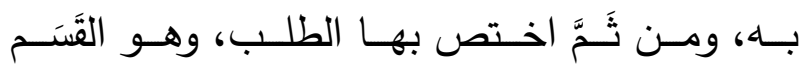

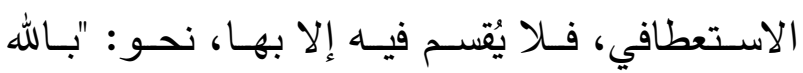
أخبرنـي"، "بـالله هـل حضـر فـلان؟؟ أي أسـألك بـالله

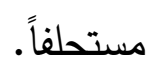

-الرابع: تختص الـ "البـاء" بجواز حذفها وجرِّ

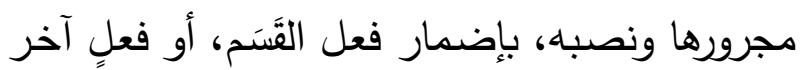

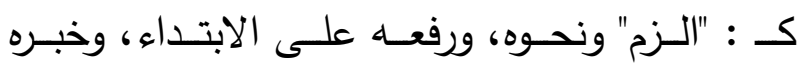
يُحذف (؟).

"ومن الأدلة على إفادة الباء للقسم:

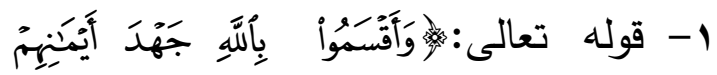

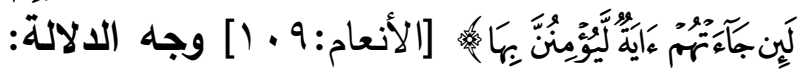

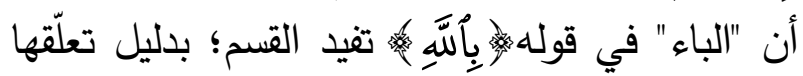

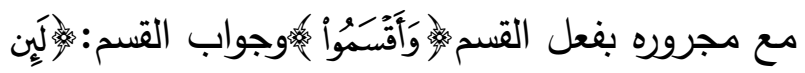
.
المســألة الثانيـة: مَنْ قـال لعبدين من عبيده:

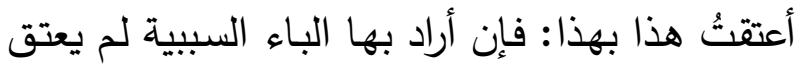
الثاني، وإن أراد بها الظرفية عتق الثاني أيضاًً(1). المسألة الثالثة: مَنْ قال: وقفتُ هذا بهذا، فإن أراد أن هذا سبب وقف هذا؛ لم يصر وقفاً، وإن أراد "في" الظرفية صار وقفاً (؟). المبحث العاشر

دلالة الباء على القَسَم وتطبيقاتها الفقهية المطلب الأول: معنى القَسَم وإلمُقْسَم لفةً: القسم: هو اليمين بالله تعالى (")، وهو اسم مِنْ:

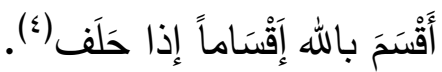

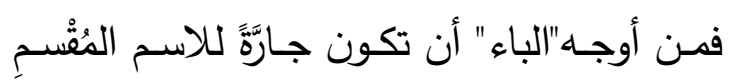
به، وتسمى "باء القسم"، وهي أصل حروف القسم. * والبـاء أصل حروف القسم، ولـذا اختُصـت عن سائر حروف القسم بأربعة أمور: -الأول: أنهــا تــدخل علـى الضــمير والاســم

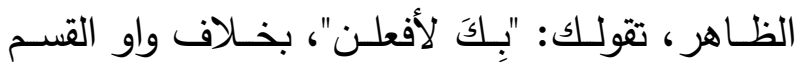
فإنها تدخل على الاسم الظاهر فقط. -الثاني :أنـه لا يجب حـف الفعل معهـا، بـل

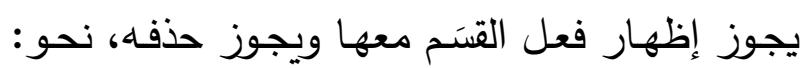
(1) (1) (1) المصدر السابق.

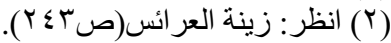

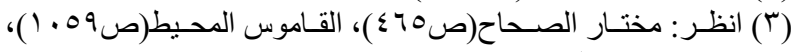

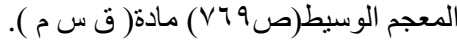

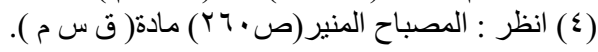




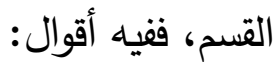

الأول: أنـه إذا حُذَفت بـاء القسـم جـاز نصـب المقسم به بإضمار فعل القسم، أو فعل آخر كـ " الزَمْ " ونحوه، وجاز رفعـه على الابتداء، وخبره محذوف ولا يجوز جره.

الثاني: أنه يجوز جره أيضاً .

الثالث : أنـه لا يجـوز نصـبه إلا في حـرفين: قضاء الله ، وكعبة الله.

وقـد رجّـح الإمـام السـيوطي القـول الأول وهـو جواز نصبا بإضمار فعل القسم، ورفعه على الابتداء ويكون خبره محذوفاً (؛).

المطلب الثـاني: تطبيقـات فقهيـة على دلالـة الباء على القسم: المسألة الأولى: لو قال المكلف: شهدت بالله لقد كان كذا وكذا؛ انعقدت يمينه عند الحنابلة (०). المسـألة الثانيـة: لو قال: عزيمـةً بالله لقد كان

كذا وكذا؛ انعقدت يمينه(T). المسأنة الثالثة: لو قال لغيره: أقسم عليك بالله،

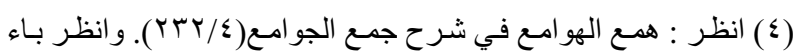

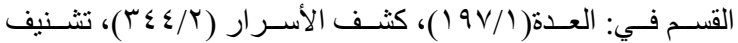

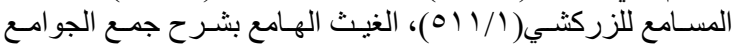

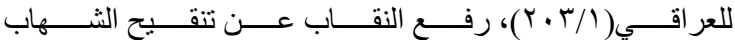

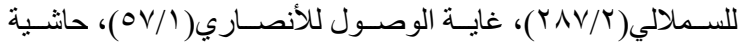

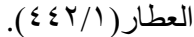

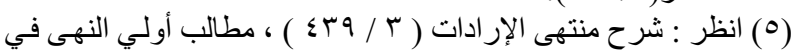

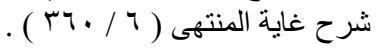

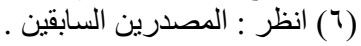

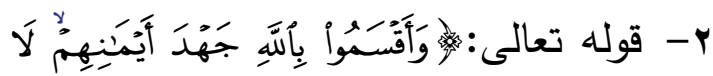

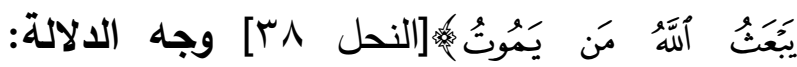

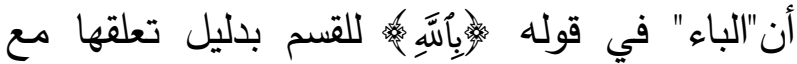

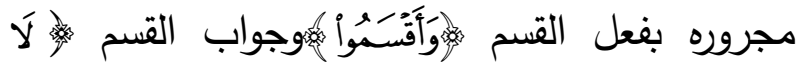

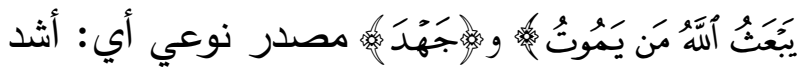
أيمانهم، وأي: أشد إقساماتهم، ويجوز كونه حالاً لأنه مصدر أُريد به الصفة، أي: جاهدين أنفسهم (').

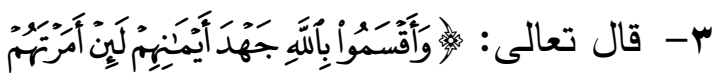

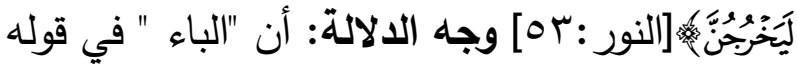

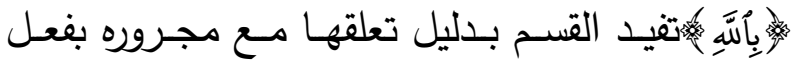
القسم

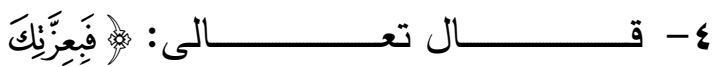

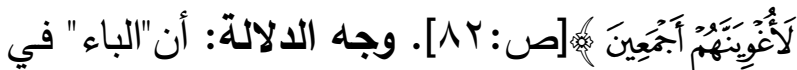

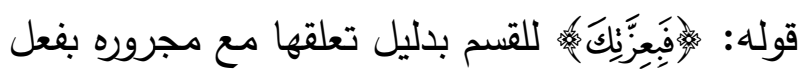
القسـم المحذوف جـوازاً، وتقديره: " أقسـم " أو نحـوه،

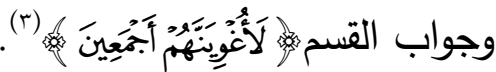
*رأي العلماء في دلالة الباء على القسم: لم أقفف على من مَنَعَ مجيء الباء للقسم إلا ما

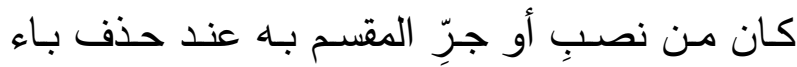

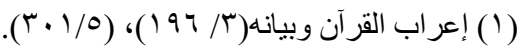

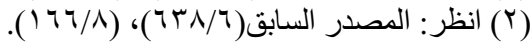

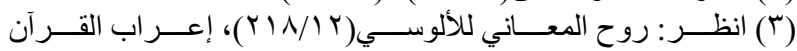

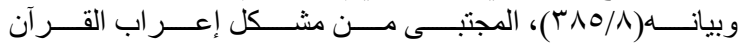
$(1 \cdot V) / 4)$ 
- المسألة الأولى: قال العيني في قوله تعالى:

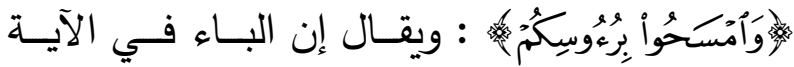
للاستعانة، وإن في الكـلام حذفاً وقلباً؛ فإنَّ (مَتَـحَ)

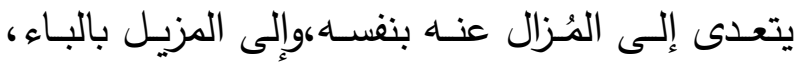

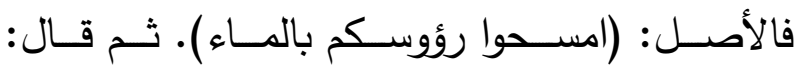
والتحقيق في هذا الموضع أن الباء للإلصاق(آ). - المسألة الثانية: في قوله ( ثم اقرأ بما تيسر معك من القران) قال المباركفوري: قال الأبهري:

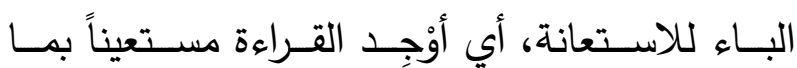
تيسر (v) - المسألة الثالثة: قال ابن علان (^)في شرح

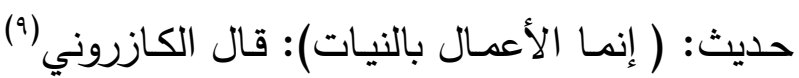
في (شرح الأربعين): الباء فيه للاستعانة(·) .

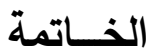

بعد انتهاء هذا البحث المتواضع في حرف الباء

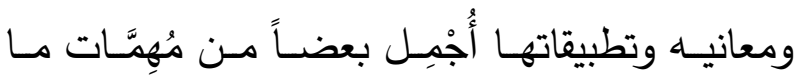
اشتمل عليه في الأمور التالية :

أولاًا : أن حروف المعاني بابٌ في علم الأصولِ أصيل ، وهو أيضاً من مباحث علم النحو .

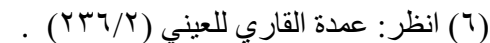

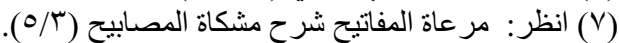

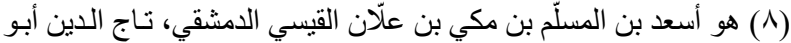

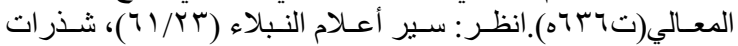

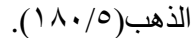
(9) هو محمد بن بيان بن محمد الكازَرُوني، أبو عبد الله، قال عنه الذهبي:

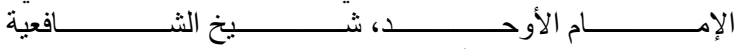

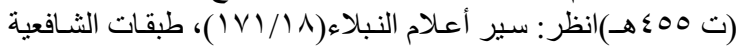

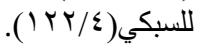
(• (1) انظر: دليل الفالحين في شرح رياض الصالحين ( 1 / عـ ).
أو أسـألك بـالله لتفعلنَّ كذا، وأراد يمين نفسـه؛ فهي

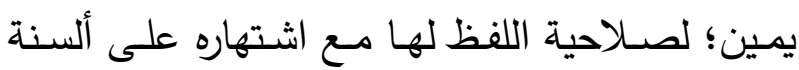

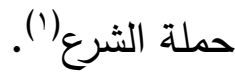

$$
\text { المبحث الحادي عشر }
$$

\section{دلالة الباء على الاستعانة وتطبيقاتها الفقهية}

$$
\text { المطلب الأول: معنى الباء للاستعانة: }
$$

قولهم : البـاء قد تفيد الاستعانة ، وهي التي كي

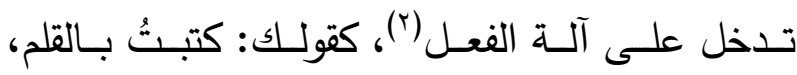

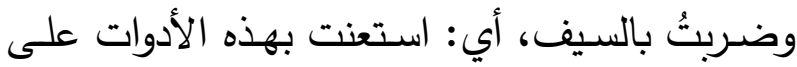

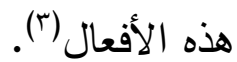

فائدة: يسمي ابنُ مالك هذه الباء باء السببية،

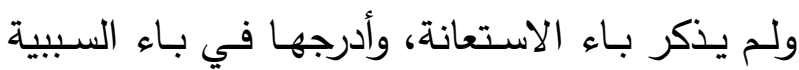

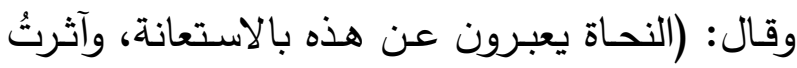
التعبير بالسببية؛ من أجل الأفعال المنسوبة إلى اللى الله تعالى، فإنَّ استعمال السبب فيها يجوز ، واستعمال

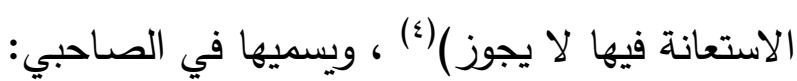

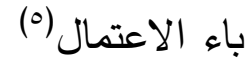

المطلب الثـاني: تطبيقـات فقهيـة على على دلالة الباء على الاستعانة:

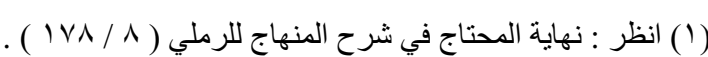

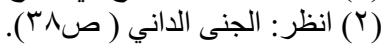

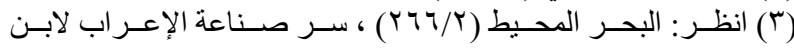

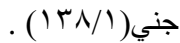

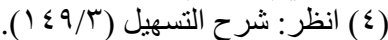


الثــرعية وعلـوم العربيــة يكِّــل بعضــها بعضـاً،كما هـو الحـال بالنسـبة إلـى العــوم

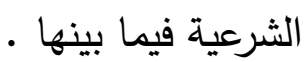

ب- أن يعنـي المتخصصـون في علم أصـول الفقه - بل وفي سائر العلوم الثرعية سبعوم العربية ؛ فإنها لغة الكتاب والسنة . فهرس المصادر والمراجع ا ـ إحكـام الإحكـام شـرح عمـدة الأحكـام ، ابن دقيق العيد(r • Vهـ)مطبعة السنة المحمدية. r. الإحكــام فــي أصـــول الأحكــام ، ابـنـ

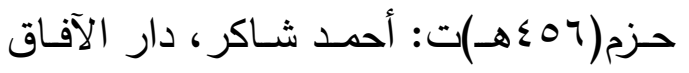
الجديدة، بيروت.

r. الإحكام في أصول الأحكام ، سيف الآمدي

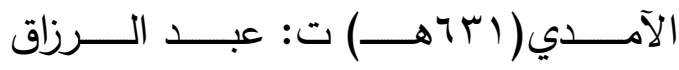
عفيفي،المكتـب الإســلامي، بيـروت، طب ، ا هـ

ـ ـ أحكام القرآن ، ابن العربي(س \& 0هـ)ت:محمد عطا ، دار الكتب العلميـة ، بيروت ،طا $. \Delta 1 \leqslant . \wedge$

هـ أدب الكاتب ، أو أدب الكُتّاب ، ابن قتيـة ، ت: محمد الدالي ، مؤسسة الرسالة. 7 ـ ارتثـاف الضَّـرَب مسن لســان العـرب ، أبـو

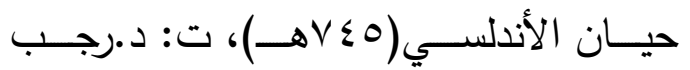

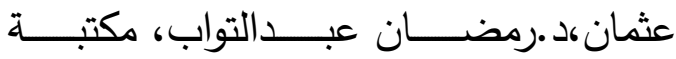

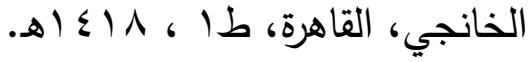

ثانيـاً : أن الحـرف فـي قـول الأصـــوليين "حروف المعاني" لا يُراد بـ اصطلاح النحاة ، وإنما مدلوله اللغوي ، فلا تثريب على الأصوليين أَنْ ذكروا في هذا الباب حروفاً وأسماءً . ثالثاً : لدراسـة حـروف المعـاني أهميـة كبيـرة وفائـدة عظيمـة فـي فهـم معـاني نصـوص الكتـاب والسنة، وكم من حكمٍ اختلف باختلاف معاني الحرف الواقع في النص الشرعي • رابعاً: يأتي حرف الباء في لسـان العرب مفيداً معاني كثيرة أورد منها العلماء أكثر من أربعة عشر معنى ، وإنْ تقاربَ بعضُ تلك المعاني التي ذكروها. خامساً: أبرز معاني الباء التي أثَّرت في فروع الفقـه هـو الإلصـاق والسـببية والتعديـة والمصـاحبة والتعويض والتبعيض والقسم. وأوصي بما يلي :

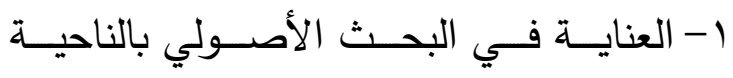

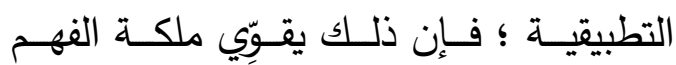
للقواعد، والاستتباط للأحكـام ، كمـا يكثـف عن أسباب كثير من الاختلافات الفقهية . Y-الرجـوع عنــد البحــث إلـى مصــادر العلــم المبحوث و مـا منـه استقى؛ وقـد رأيـت في هذا البحث اشتراك كتب علم أصسول الفقهـ وكتب علم النحو في مادته العلمية ، وانفراد كل منهما في بعض المواضـع بإفادة مـا لم

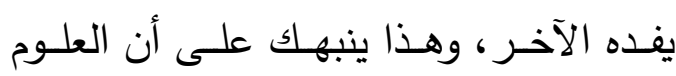




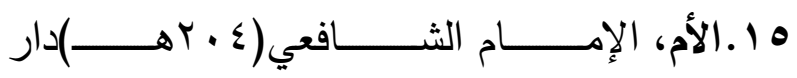

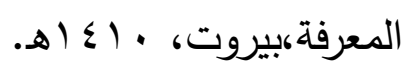

1 ا.أنوار التنزيل وأسرار التأويل ، المعروف بتغسير

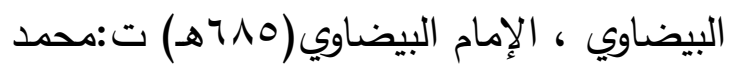

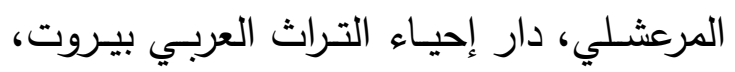
طا ، الها

V الآيات البينات على شرح المحلّي ، ابن قاسم

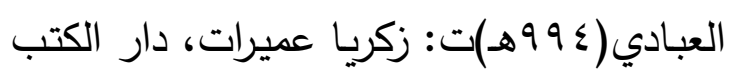

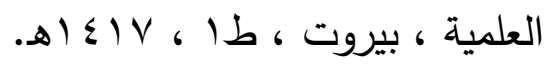

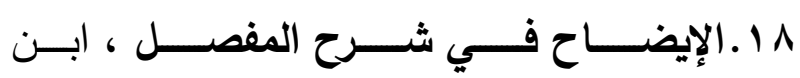
الحاجب(7 § آهـ)، ت: د. موسى العليلي، وزارة

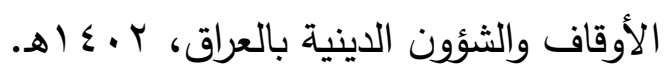

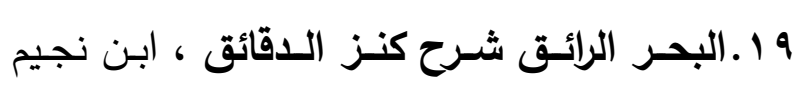

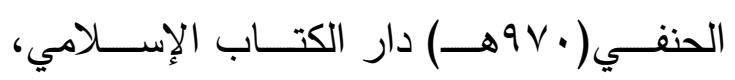

$$
\text { . ז }
$$

•r.البحر المحيط في أصسول الفقـه ، بدر الدين

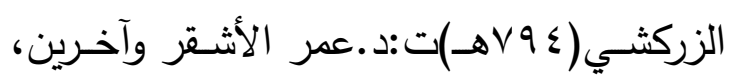

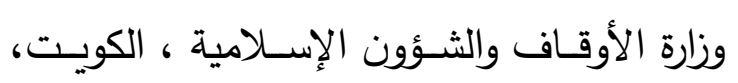

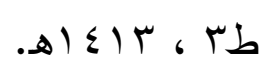

ا Y.بـائع الصـنائع في ترتيب الثـرائع، الكاسـي

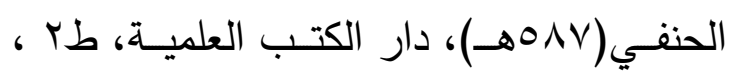

$$
\text { .ه } 18
$$

r. r.البــدر التمــام شـرح بلــوغ المـرام ، الحسـين المغربي(9 11 (1) هـ)، ت: علي الزبن، دار هجر ، طا (اله
V. إرواء الغليـل فـي تخـريج أحاديـث منــار

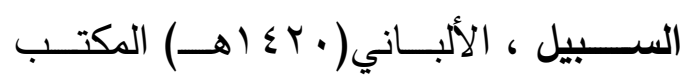

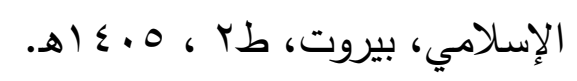
^. الأزهيـة في علم الحروف ، علي بن محمد

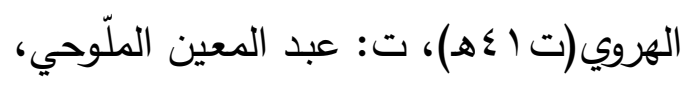

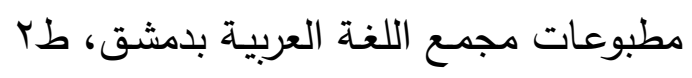

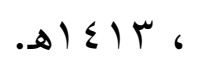
9 ـ أسـنى المطالب في شـرح روض الطالب ،

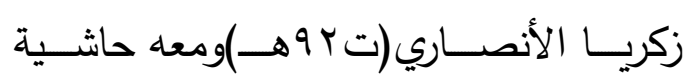

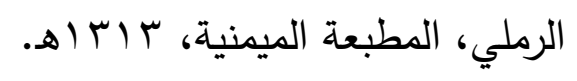

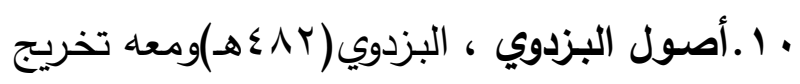

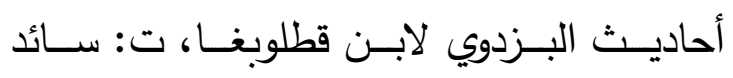

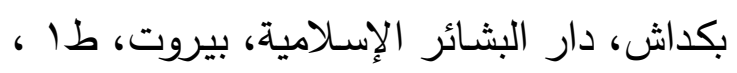
דr 1 أصسول السرخسي ، السرخسي(ب^§هـ)ت: أبو

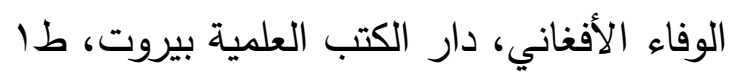
.ه $\{\leqslant$ ،

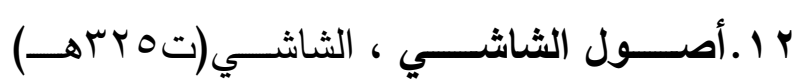

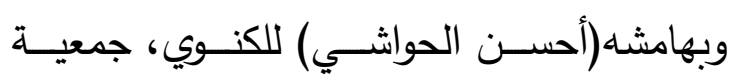

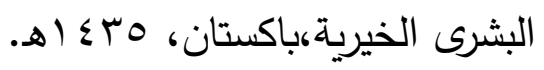
با 1 .إعــــراب القـــرآن وبيانـــهـه ، محيــي الــدين

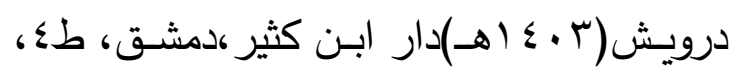
10 ؛ ا.الأعـلام ، خيـر الدين الزركلي(79 باهـ) دار

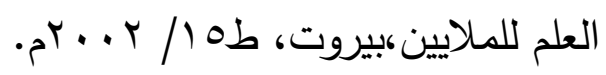


• r.ترتيـب المــارك وتقريسب المسـالك ، القاضـي عياض(؟ § 0هـ)ت: ابن تاويت الطنجي وآخرين

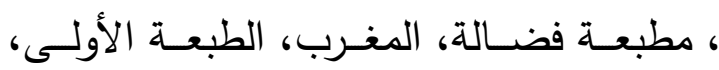
.01970

اس.تثنيف تشنيف المسامع بجمع الجوامع ، بدر

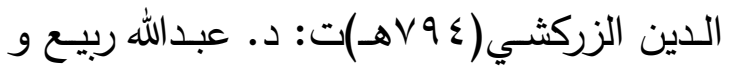
د. سـيد عبدالعزيز، مؤسسـة قرطبـة ، القـاهرة،

$$
\text { ط }
$$

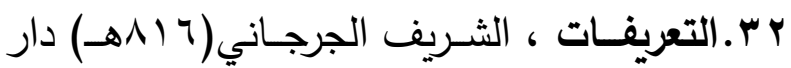
الكتب العلمية بيروت، طا ، ب مـ اهـ.

rس.تفسير الجلالين ، جلال الدين المحلي(ء؟1هـ)

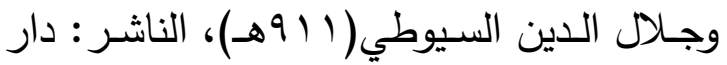

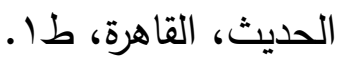

ع س.التفسـير الكبيـر، (مفـاتح الغيب) فنـر الدين

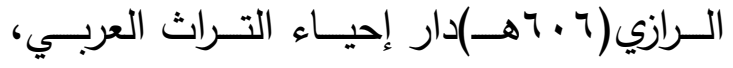

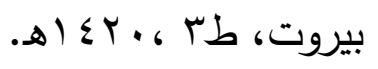

هـ ــ التقربــبـ والإرشـــاد (الصــفير) ، أبــو بكـر

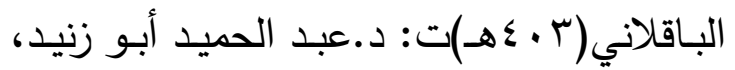
مؤسسة الرسالة، بيروت، طץ ، 11 إ الهـ. צr.التقرير والتحبير على تحرير الكمال بن الهمام،

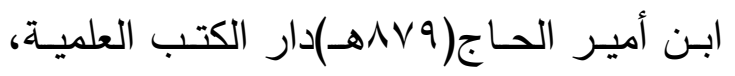

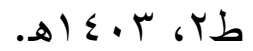

rV التلخـيص فـي أصـول الفقـهـه ، إمـام الحـرمين

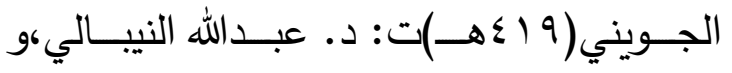

ب r. البرهــان فـي أصــول الفقــهـ ، إمـام الحـرمين

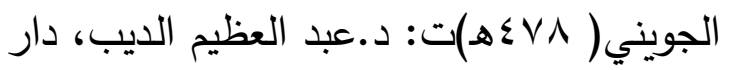

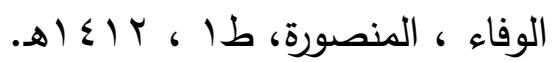

צ ץ.بغيـة الوعـاة في طبقـات اللغـويين والنحساة ، جـلال الدين السيوطي(1) الفضل إبراهيم، مطبعـة عيسى البابي الحلبي،

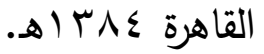
ه ب. البنايــــة شـــرح الهـايــــة ، بـــدر الــدين

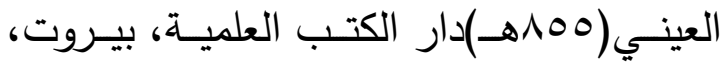
ط. (1) צY.تـاج العـروس مسن جـواهر القـاموس ، محمد مرتضى الزبيدي(0 ـ ب اهـ)ت: علي شيري، دار الفكر ، بيروت ، ع إع اله.

r. rV ت: علـي البجـاوي ، الناشـر : عيسـى البـابي

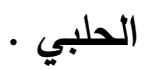

^ץ.التحبير شرح التحرير في أصول الفقه ، علاء

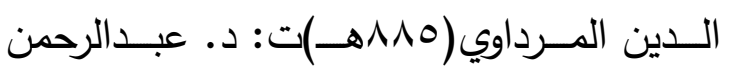

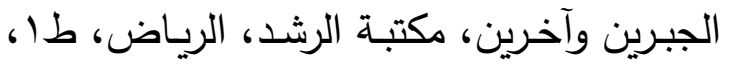
.ه $\leqslant$ I I q.تحفـة المحتـاج بثـرح المنهـاج ، ابـن حجر

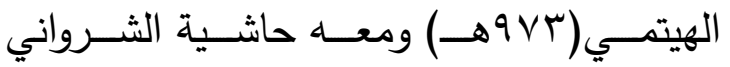
والعبادي، المطبعة الميمنية، مصر 1 ابا أه. 
؛ ؛ ـالجنى الداني في حروف المعاني ، المرادي،

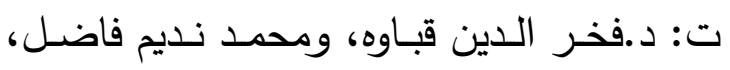
دار الكتب العلمية بيروت، طا ، با ــ اهـ. ه ؛ الجـواهر المضـيّة في طبقـات الحنفيّة ، عبد

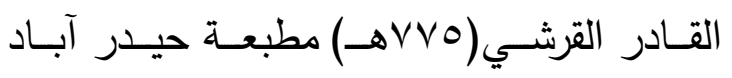
الدكن، الهند rrT آهـ.

\ ؛ .حاثية الجمل على شرح منهج الطلاب لزكريا الأنصـاري، المسماة بـ(فتوحات الوهاب بتوضيح

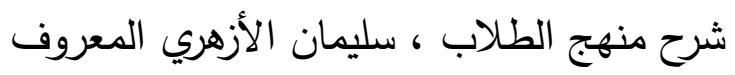
بالجمل (ع • r اهـ) دار الفكر ، بيروت. V V .حاشـية الاسـوقي على الشـرح الكبير للشسيخ

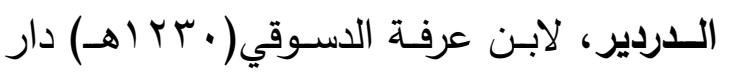
الفكر ^ ـ .حاشـية العطـار علـى جمـع الجوامسع ، حسـن

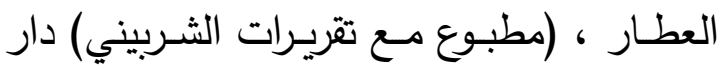

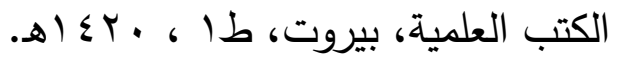

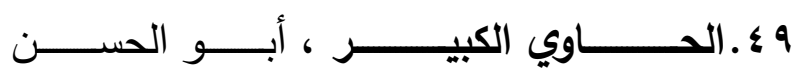

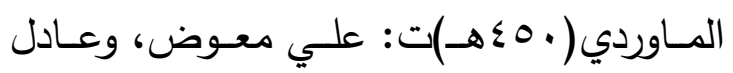

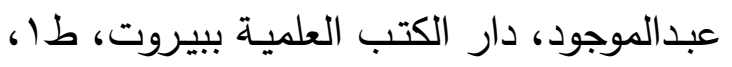
. $1 \leqslant 1 \leqslant$

• ه.حروف المعاني ، أبو القاسم الزجاجي، المتوفى

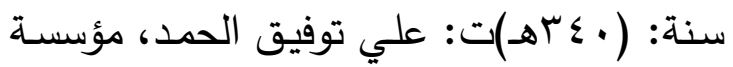

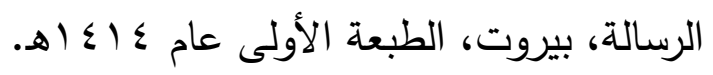

د.شـبير العهـري،دار البشـائر ، بيـروت، طاه .ه $1 V$ ^ץ.التلويح إلى كثف حقائق التنقيح ، سعد الدين التفتازاني (r VAه) مطبوع مع (التوضيح) لصدر

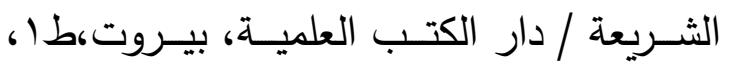
.ه (1)

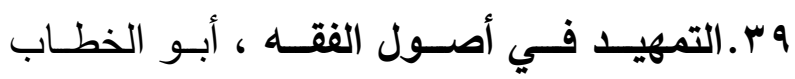

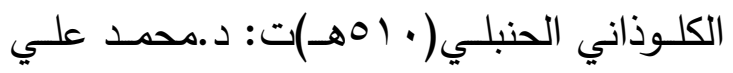
إبراهيم،د.مفيد أبو عمشة، الناشر ، مركز البحث

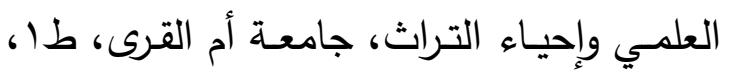
. ه) 1 • ـــــــــيب اللغـــة ، أبــو منصـــور الأزهــري

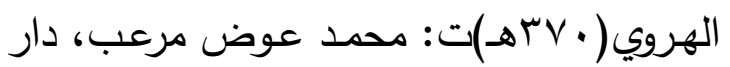

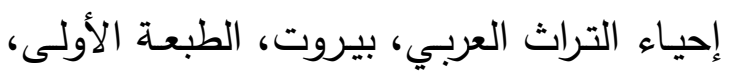
.5 . . اءـ.التوضــيح علــى التنقــيع ، صــدر الثـريعة

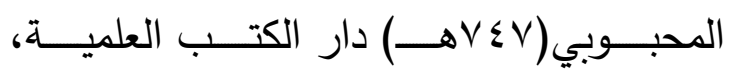
بيروت،طا، 77 إ (هـ. ץ ـ ـ توضيح المقاصــ والمسـالك بثـرح ألفيـة ابـن

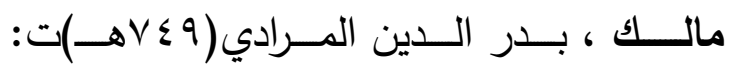

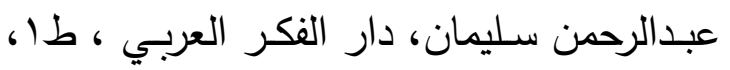
ه بـ ـ التوضــيح لثــرح الجــامع الصــيح ، ابـن

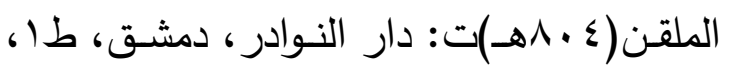


عبــ البـاري ، دار الكتب العلميـة ، بيـروت ، ه 10

هـ ـزينـة العرائس مـن الطُرَف واللنفــائس ، جمال الدين ابن عبد الهادي ، ت :د.رضوان غريبة ،

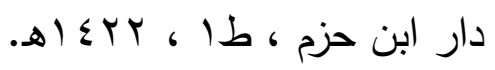

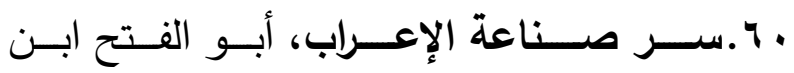
جنـي(ت צrاهـ)، ت: د. حسـن هنداوي، دار

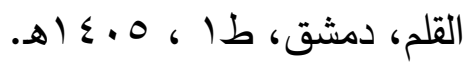

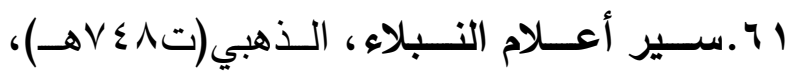
ت:شعيب الأرناؤوط وآخرين، مؤسسـة الرسالة،

$$
\text { طץ/ 0. } 1 \text { أه. }
$$

r ا.شذرات الذهب في اخبار مِنْ ذهب ، ابن العماد الحنبلي (ت 9 • • اهـ) دار الفكر ، بيروت.

با.شرح ابن عقيل على ألفيـة ابن مالك ، ومعهد كتاب (منحـة الجليل بتحقيق شرح ابن عقيل) لمحمد محيى الدين عبدالحميد، دار التراث ،

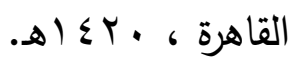

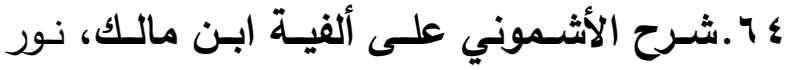

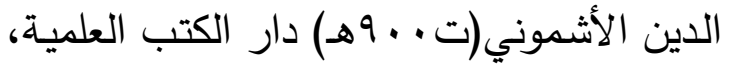

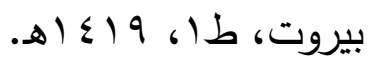

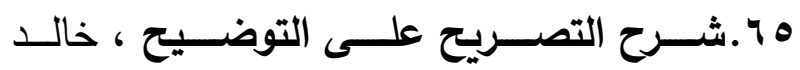

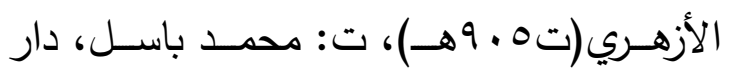

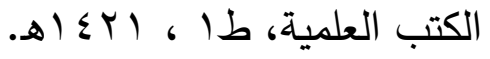

1هـروف المعـاني وأثرهـا في اختلاف الفقهاء، د.حسـين الترتـوري، مقدمـة إلى قسـم الثـريعة بجامعة أم القرى.

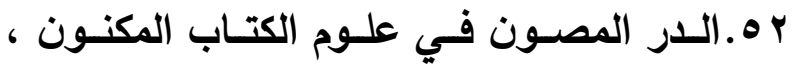

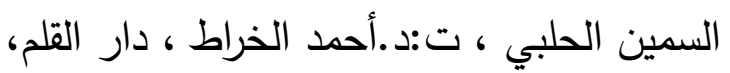

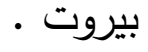
به ــليل الفـالحين لطرق ريـاض الصـالحين ، ابن علان الصديقي(OV ـ ا هـ)ت:خليل شيحا ، دار

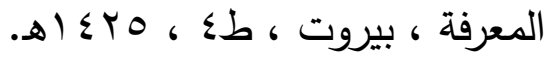
ـ ه.الــيباج المـذهب فـي معرفـة أعيـان علمـاء المـذهب، ابن فرحون(ت 9 \هـ)، الناشـر : دار

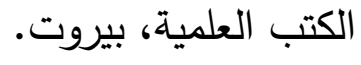

هـ الرســـالة فـــي أصــــول الفقــــه ، الإمــام

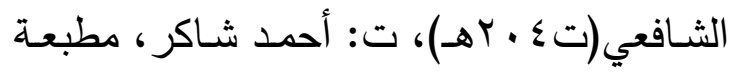

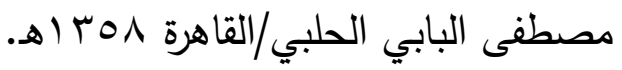
ه.رصــف المبــاني شــرح حــروف المعــاني،

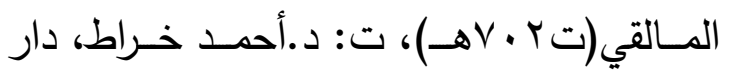

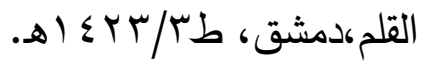

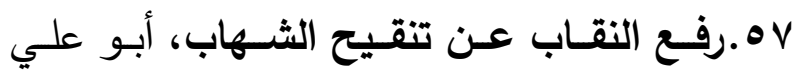
الشوشــاوي(199هـــات :د.أحمد الســراح، ود. عبدالرحمن الجبـرين، مكتبـة الرشــ، الريـاض،

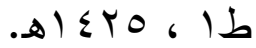
هـ.روح المعاني في تفسير القرآن العظيم والسبع

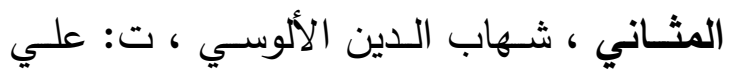


العدوح مختصر خليل للخرشي ، (ومعسه حاشية

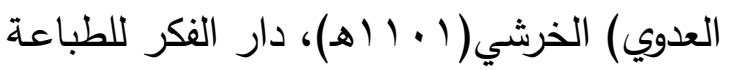

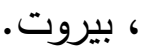

§ V.شـرح المفصل ، ابن يعيش(T آهـ)ت:د.إميل

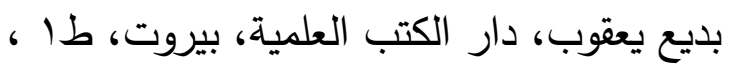
. أه $\leqslant r$

ه V.شرح منتهى الإرادات ، البهوتي(ت إن ـ ( ه)دار عالم الكتب، بيروت، طا ، ـ إع الهـ

צ.V.الثـعر والثـعراء ، ابن قتيبـة ، دار الحديث ،

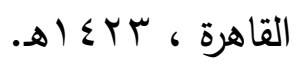

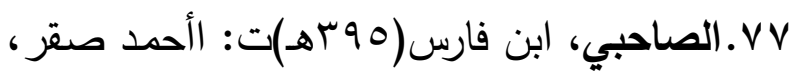

$$
\text { دار إحياء الكتب العربية. }
$$

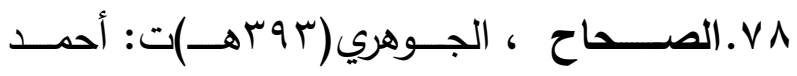
عبدالغفور عطار، دار العلم للملايين بيروت،

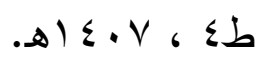

V9. صـحيح البخـاري ، ت:محمد فؤاد عبدالباقي،

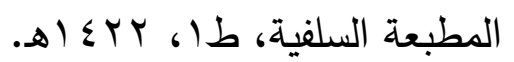

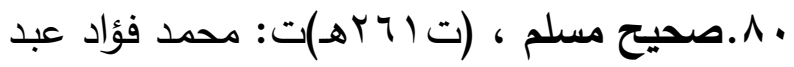
الباقي، دار إحياء التراث العربي،بيروت.

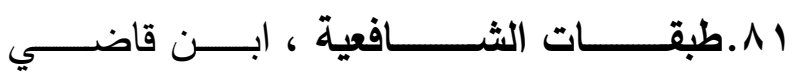
شُهبة(ت (10)هـ)، ت: د. دافظ عبدالعظيم خان،

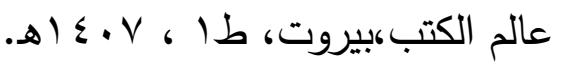
r.A r.طبــات الثـــافعية الكبـرى ، تـاج الـدين ابـن

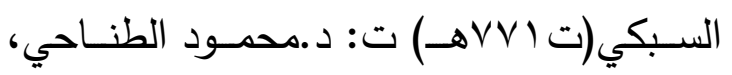

7 . 4 .شـرح التــويح علـى التوضـيح ، سـعد الـدين

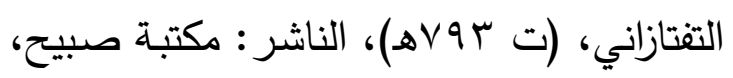

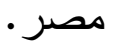

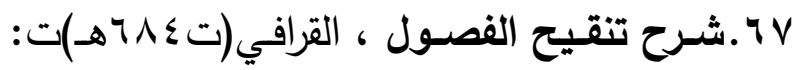

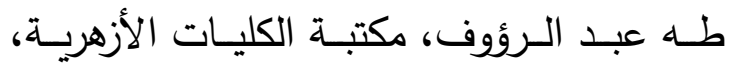

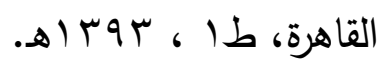
1 4 .شــــرح شــــاواهد المغنـــي ، جــلال الــدين

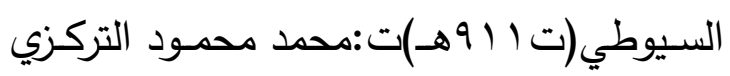

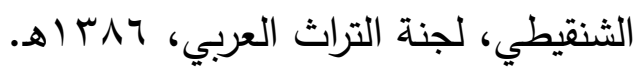
9 9 .شـرح العمـدة فـي الفقـهـه ، شـيخ الإســلام ابن

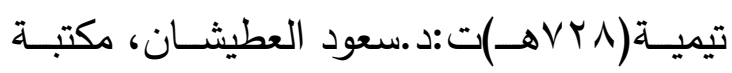

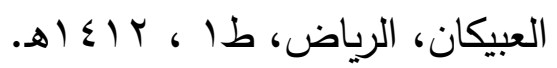
. . . . . . .

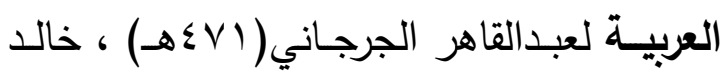

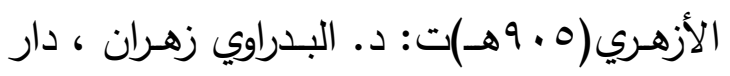

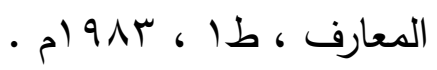

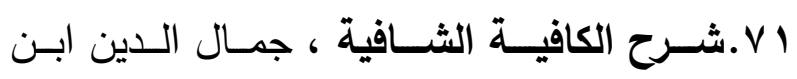

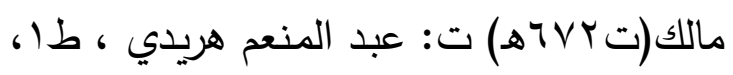

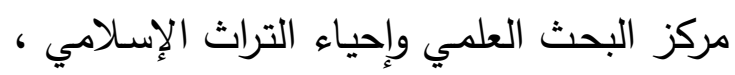
جامعة أم القرى ، مكة المكرمة .

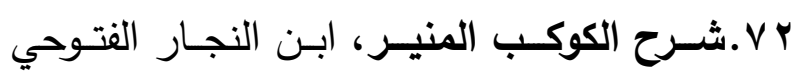

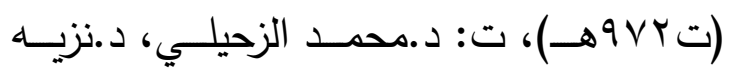

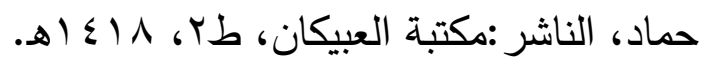


ـ .فتح الباري بشرح صحيح البخاري ، لابن حجر

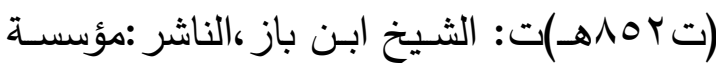
مناهل العرفان،بيروت.

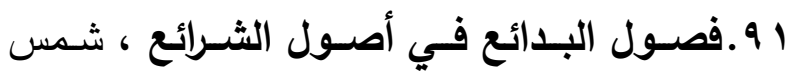

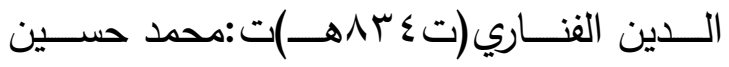

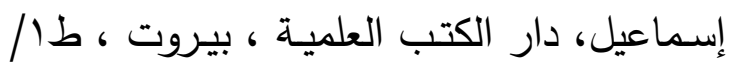
هـ $\{Y V$

r 9 .الفوائد البهية في تراجم الحنفية ، أبو الحسنات

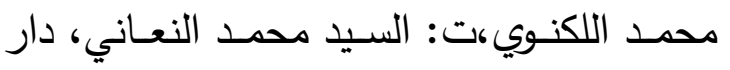

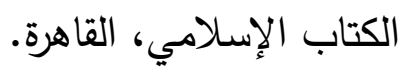

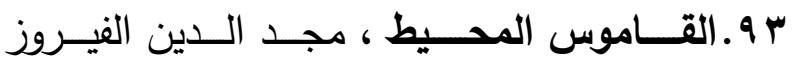

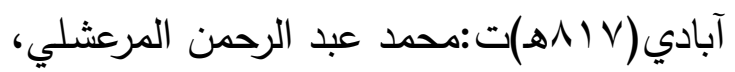

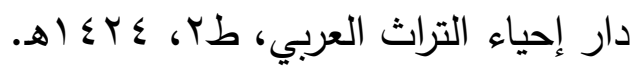

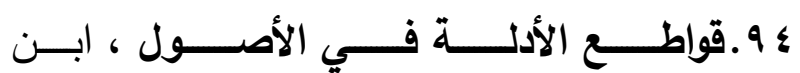

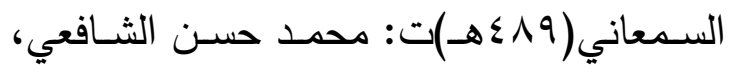
دار الكتب العلمية ،بيروت، طا، 11 إ أهـ.

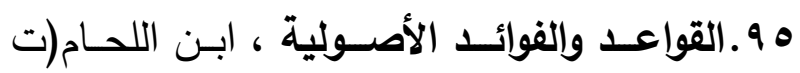

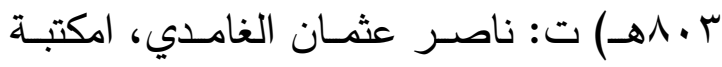

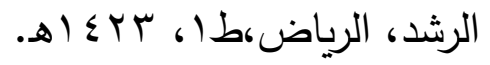
9 9.الكـافي شـرح أصسول البـزدوي ، حسـام الدين

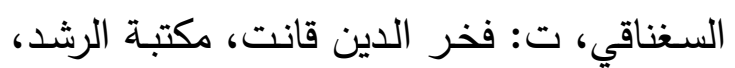
الرياض ، طا ، ب اله اله.
ود.عبـــــالفتاح الحلـــــو، دار هجـــــر ، طن

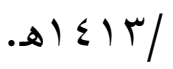

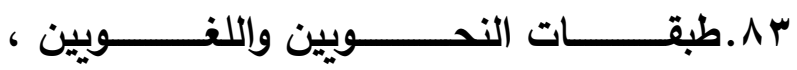

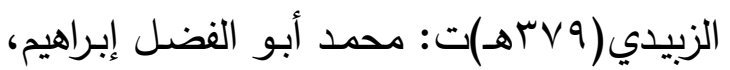
دار المعرفة، الطبعة الثانية.

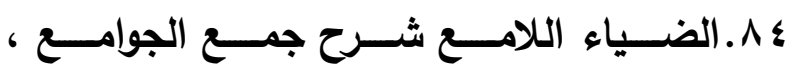

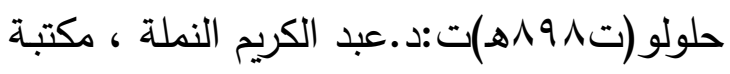

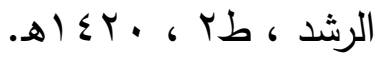
هـ. العــدة فـي أصــول الفقــهـ ، للقاضــي أبـي

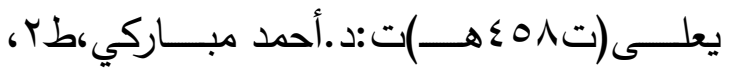
.ه) $\leqslant$.

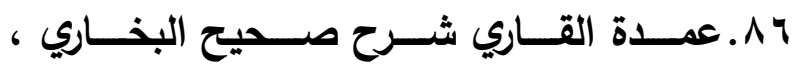
للعينـي(ت 100هـ)، الناشـر : دار إحيـاء التراث العربي،بيروت.

Av العوامل المائة النحوية في أصول علم العربية

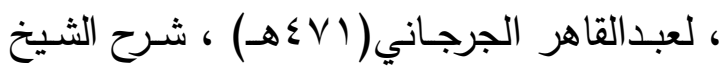

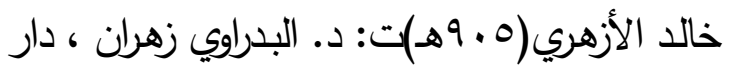

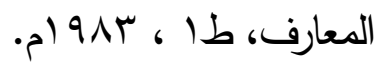
1^ـ غايـة الوصـول في شرح لب الأصسول ، زكريـا

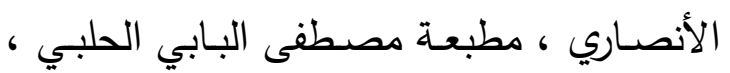

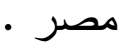
9 هـ الغيث الهامع شرح جمع الجوامـع ، ولي الدين العراقي، ت: محمد تامر حجازي، دار الكتب لبع العلمية، بيروت ، طا، 0بـ اهـ. 
؛ ـ 1. الكواكب الدراري في شرح صحيح البخاري،

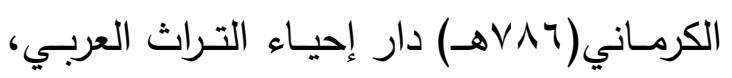

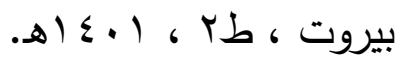

هـ ـ ـ الكواكب السـائرة بأعيـان المائـة العاشـرة ، الغزي(آج • (هـ)ت: خليل المنصور، دار الكتب

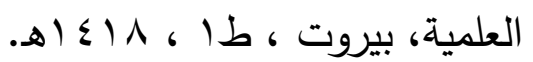
4 ـ 1 . الكوكب الـدري في كيفيـة تخريج الفروع

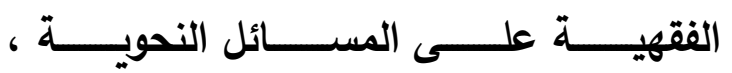
الإسنوي(VVY) ت: د.عبد الرزاق السعدي، دار

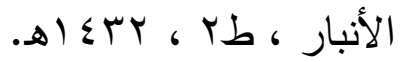

v • . . اللباب في علل البناء والإعراب ، أبو البقاء

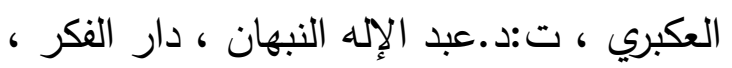

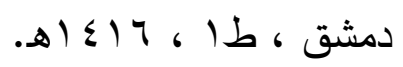

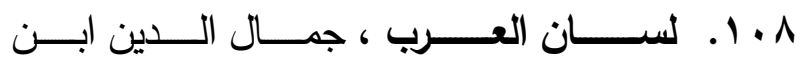

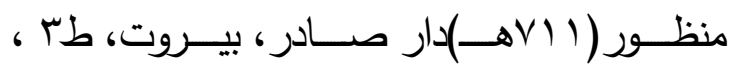

.ه $\{\leqslant$

9 ـ 1 ـ المبدع في شرح المقنع ، برهان الدين ابن

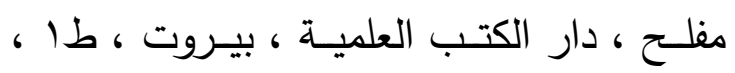
.ه

ـ11. المجتبى من مُشكِل إعراب القرآن ، د. أحمد

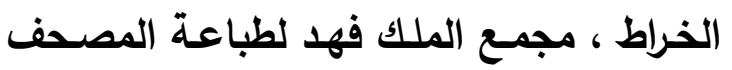

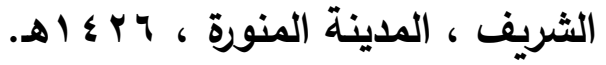
111 11. مجمــوع الفتــاوى ، شـيخ الإســلام ابـن

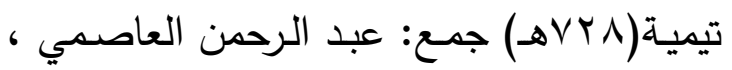
دار عالم الكتب ، الرياض ، ب إعأهـ الهـ
9 V الكافيـة في علم النحو و الشـافية في علمي التصسريف والخطط ، ابن الحاجب(7 ـ7 هـ)ت د.صالح الثاعر ، مكتبة الآداب، القاهرة. 19.الكامل في اللغة والأدب ، أبو العباس المبرد ،

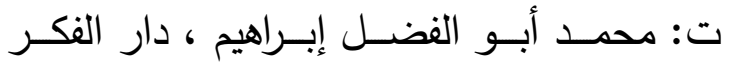

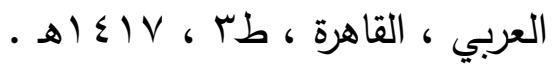

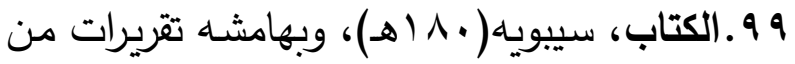
شرح السيرافي، وشرح الشواهد للأعلم الشنتمري،

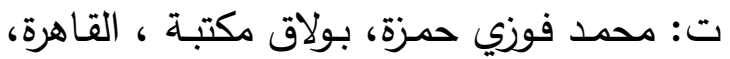
. (ד I . . . . الكثـاف عن حقائق التتزيل وعيون التأويل

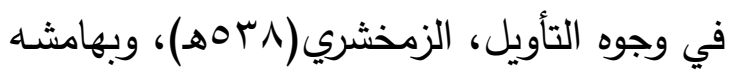
تخريج أحاديث الكشاف، ت: الشربيني شريده، دار الحديث ، القاهرة ، سب إهـ اله.

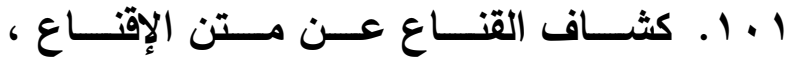
البهوتى( (ه ـ (هـ)دار الكتب العلميـة، بيروت، . r • 1. كشف الأسرار شرح أصول البزدوي ، عبد العزيز البخاري(• • الهـ) دار الكتاب الإسلامي. ب. 1. كشف الأسرار شرح المصنّف على المنار ، أبو البركات النسفي( • (Vه)، ومعهد شرح نور

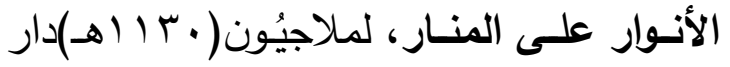

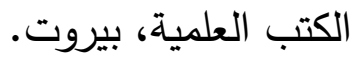


11 1. معجم مصسطحات الأصسول ، هيث هـلال ،

ت: د. محمد ألتونجي ، دار الجيل ، بيروت ،

$$
\text { طـ }
$$

19 1 . معجـم مصسطات أصسول الفقــه، د.قطب مصــفى سـانو ، دار الفكـر المعاصـر ، طس،

$$
\text { . ) } \leqslant Y V
$$

• r ا ـ مصــابيع المغـاني فـي حـروف المعـاني،

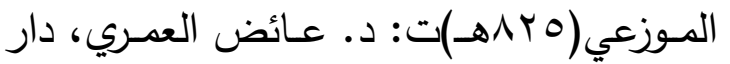

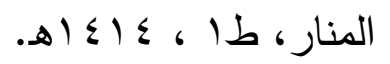

ا ץ ا ـ المصباح المنير في غريب الثرح الكبير،

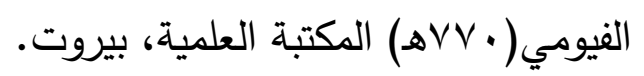

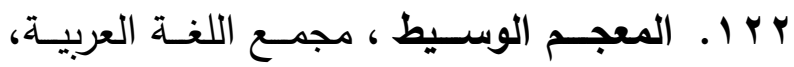
عنايـة: د.إبراهيم أنيس وآخرين، دار المعارف،

$$
\text { ط }
$$

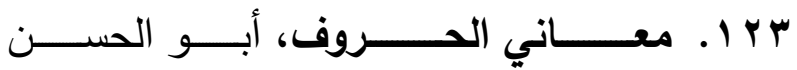

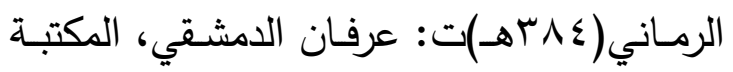

$$
\text { العصرية، بيروت، بـ اهـ. }
$$

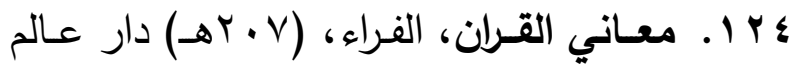

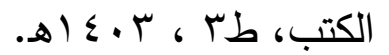

ه ץ ا . معجم مقاييس اللغة، ابن فارس(0 بهـ)ت: عبد السلام هارون، دار الفكر، و وب اهـ.

צ r ا . معلمـة زايـــ للقواعـد الفقهيـة والأصـولية، مجموعة من الباحثين، نسخة آلية في الحاسب r 1 ا ـ المحصـول في أصسول الفقـه ، فخر الدين الـرازي( ج ـ 7هـ)ت: د. طـه العلـواني، مؤسسـة

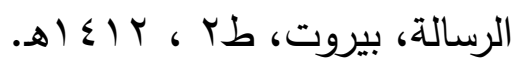
ץ 1 ا. مختـار الصـحاح ، الـرازي(777هـ)المطبعة الأميرية، بولاق، مصر ، طץ ، 97 الهـ.

ع 1 ا. مختصر ابن الحاجب ، المسمى بـ( مختصر

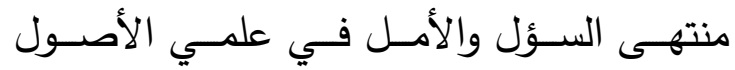
والجدل )، ابـن الحاجب (7 § آهـ) ومعسه شـرح العضـــد، وعلــى الشــرح حاشــيتا التقتـــازاني والجرجـاني ، الناشـر : مكتبـة الكليـات الأزهريـة،

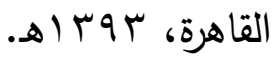

0 1 ـ ـ مرعـاة المفـاتيع شـرح مشـكاة المصـابيع ، أبو الحسن المباركفوري ، إدارة البحوث العلمية

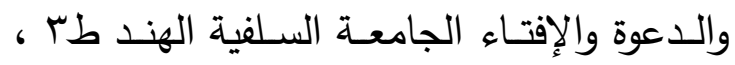
ـ أه 7 1 ـ. المستصففى مـن علـم الأصسول ، أبو حامد الغزالـي (0. 0هـ)ت: د. حمـزة زهيـر حـافظ، شركة المدينة المنورة، فرع جدة. VI I ا المسـودة فـي أصسـول الفقــهـ ، آل تيميـة،

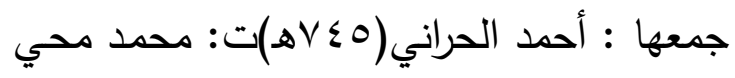
الدين عبد الحميد، دار الحديث، القاهرة، طاه . (1517 
ع ب ا. المنخول مـن تعليقات الأصول ، أبو حامد

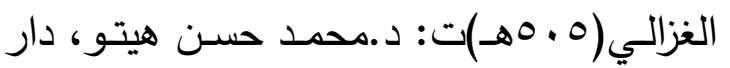

الفكر، دمشق، طץ ، 9 إ؛ (هـ.

هـ ا ـ نزهــة الألبـاء فـي طبقــات الأدبـاء، ابـن

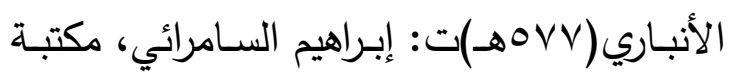

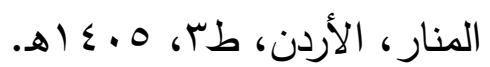

צب ا ـ نفـــائس الأصـــول شـــرح المحصـــول ،

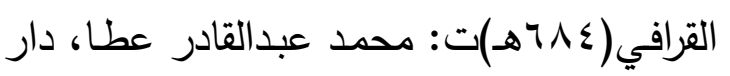

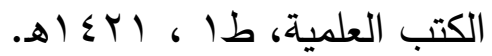

Irv

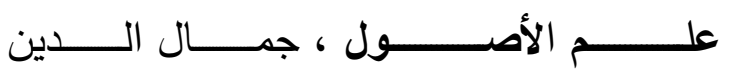

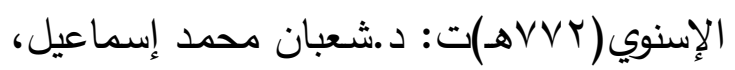
دار ابن حزم، بيروت، طا ، . بـ اله.

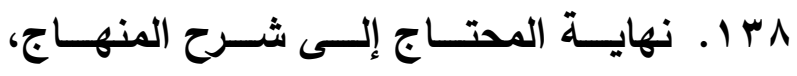

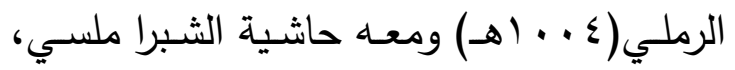
دار الفكر ، بيروت، ع • ـ أهـ.

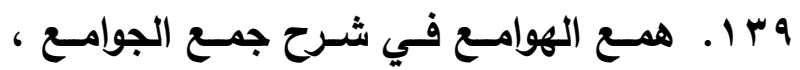

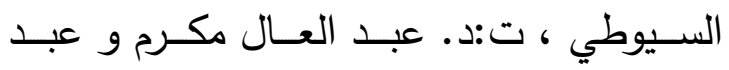

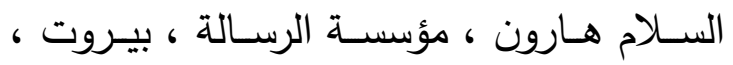

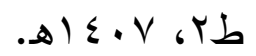
• ــ ا. ـ الواضــــح فــي أصـــول الفقـــهـه ، ابــن

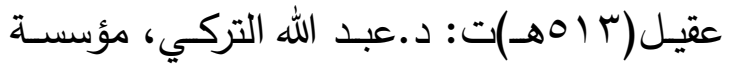

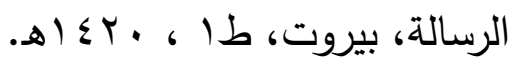

الآلي فقط ، واختص الدكتور : أسعد الكفراوي بدراسة مباحث حروف المعاني فيها.

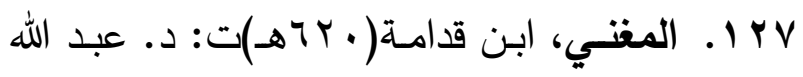

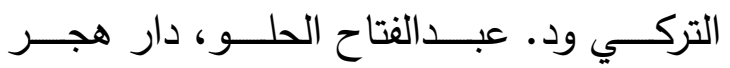
للطباعة، القاهرة، طا، ـ إ أهـ ر ا ا. المغتـي فـي أصـول الفقـهـ ، جـلال الـدين

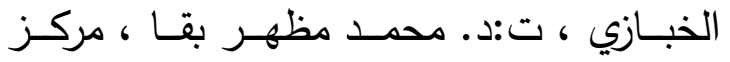

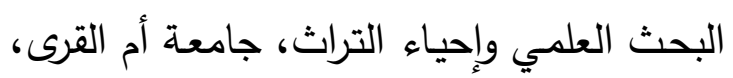
طه ، س.ك اهـ. 9 ا I. مغتي اللبيب عن كتب الأعاريب، ابن هشام

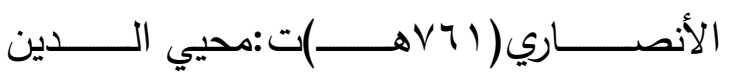

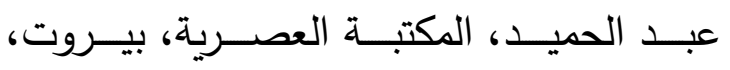

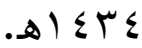

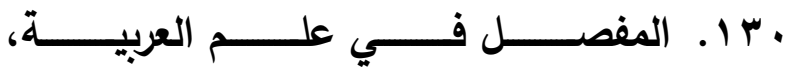

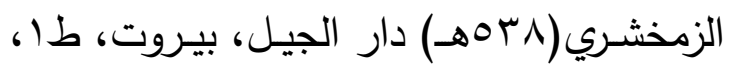
.ه $\{r \leqslant$ اب ا ـ مقاليد العلوم في الحدود والرسوم ، منسوبّ

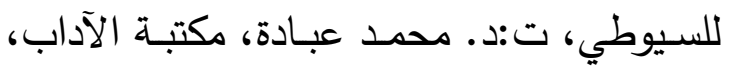

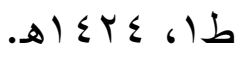

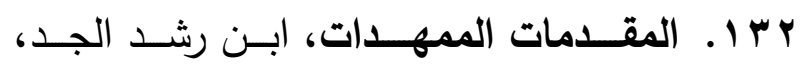
مطبوعــة مــع المدونــة الكبـرى، دار الكتبـب

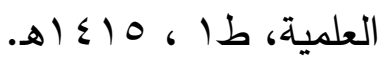
بr ا. المقصــ الأرشـــ في ذكر أصـحاب الإمـام أحمد ، ابن مفلح، ت:د.عبد الرحمن العثيمين، مكتبة الرشد، الرياض، طا ، . إئا اله. 


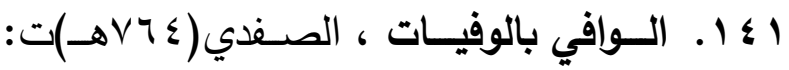

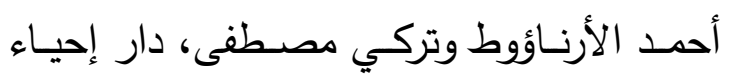

التراث بيروت، • r؟ اهـ الهـ

ץ ا 1. الـوجيز فـي تفسـير الكتـاب العزيـز ، أبـو

الحسن الواحدي ، ت:صفوان عدنان داوودي،

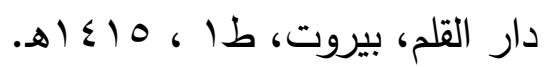




\title{
The connotations of the letter of $B \bar{a}^{\prime}$ as applied by scholars of principles of Islamic Jurisprudence
}

\author{
Dr. Abdul-Wahhab ibn Ayed Al-Ahmadi \\ Associate Professor in the Faculty of Sharia and Islamic Studies \\ Umm Alqura University, Makkah Al-Mukarrma
}

The letter of $b \bar{a}$ ' is one of hurūf al-ma 'ān $\bar{\imath}$ that was researched by both grammarians and scholars of the principles of Islamic Jurisprudence. It bears many meanings, but the most influential meanings in the provisions of Sharia are adjoining, causality, transgression, accompaniment, substitution, adverbial and oath. These meanings were not all agreed upon among the scholars; some of them disagreed in the meanings of some of them as substitutions, and the consensus on some of them as adjoining. And the validity of its implication to the rest of the meanings. It should be noted that the scholars of jurisprudence and the Islamic principles applied the meanings on the texts in the law, and in the hadith of the creation and the words of sellers and buyers, givers of charity endowments and will-writers and divorced couples and others. It is required that in order to apply these meanings on the words of people, they should speak according to the standard language fușhāa, or at least use the letter $b \bar{a}^{\prime}$ in accordance with Arabic language. 